1 Holocene thermokarst dynamics in Central Yakutia - A multi-core and

2 robust grain-size endmember modeling approach

3 Authors:

4 Mathias Ulrich $^{1 *}$, Heidrun Matthes ${ }^{2}$, Johannes Schmidt ${ }^{1}$, Alexander N. Fedorov ${ }^{3,4}$, Lutz

5 Schirrmeister $^{2}$, Christine Siegert ${ }^{2}$, Birgit Schneider $^{1}$, Jens Strauss $^{2}$, Christoph Zielhofer ${ }^{1}$

6

7 Affiliations:

$8 \quad{ }^{1}$ Leipzig University, Institute for Geography, Leipzig, Germany

$9{ }^{2}$ Alfred-Wegener Institute Helmholtz Center for Polar and Marine Research, Potsdam, 10 Germany

11 Melnikov Permafrost Institute, SB RAS, Yakutsk, Russia

$12{ }^{4}$ North-Eastern Federal University, Yakutsk, Russia

$13{ }^{*}$ Corresponding author: Mathias Ulrich, Institute for Geography, Leipzig University, 14 Johannisallee 19a, 04103 Leipzig, Germany. Email: Mathias.Ulrich@uni-leipzig.de

16 Highlights

17 - Small thermokarst lakes and basins grew rapidly during the Holocene Thermal Maximum

18 - Short-term phases of forcing climate lead to very active thermokarst processes

19 - Endmember analysis reveals different depositional environments in growing lakes

20 - Distal and proximal depositional and post-sedimentary conditions are differentiated

21 - Sedimentological and biogeochemical characteristics are weakly correlated

23 Abstract:

24 Differentiating thermokarst basin sediments with respect to the involved processes and 25 environmental conditions is an important tool to understand permafrost landscape dynamics 26 and scenarios and future trajectories in a warming Arctic and Subarctic. Thermokarst basin 27 deposits have complex sedimentary structures due to the variability of Yedoma source 28 sediments, reworking during the Late Glacial to Holocene climate changes, and different stages 29 of thermokarst history. 
30 Here we reconstruct the dynamic growth of thermokarst lakes and basins and related changes 31 of depositional conditions preserved in sediment sequences using a combination of 32 biogeochemical data and robust grain-size endmember analysis (rEMMA). This multi-proxy 33 approach is used on 10 sediment cores (each 300-400 cm deep) from two key thermokarst sites 34 to distinguish four time slices that describe the Holocene thermokarst (lake) basin evolution in 35 Central Yakutia (CY). Biogeochemical proxies and rEMMA reveal fine-grained sedimentation 36 with rather high lake levels and/or reducing conditions, and coarse-grained sedimentation with rather shallow lake levels and/or oxidizing (i.e. terrestrial) conditions in relation to distal and proximal depositional and post-sedimentary conditions. Statistical analysis suggests that the biogeochemical parameters are almost independent of thermokarst deposit sedimentology. Thus, the biogeochemical parameters are considered as signals of secondary (post-sedimentary) reworking. The rEMMA results are clearly reflecting grain-size variations and depositional conditions. This indicates small-scale varying depositional environments, frequently changing lake levels, and predominantly lateral expansion at the edges of rapidly growing small thermokarst lakes and basins. These small bodies finally coalesced, forming the large thermokarst basins we see today in CY.

Considering previous paleoenvironmental reconstructions in Siberia, we show the initiation of thaw and subsidence during the Late Glacial to Holocene transition between about 11 and 9 cal kyrs BP, intensive and extensive thermokarst activity for the Holocene Thermal Maximum (HTM) at about 7 to 5 cal kyrs BP, severely fluctuating water levels and further lateral basin growth between $3.5 \mathrm{cal}$ kyrs BP and $1.5 \mathrm{cal}$ kyrs BP, and the cessation of thermokarst activity and extensive frost-induced processes (i.e. permafrost aggradation) after about 1.5 cal kyrs BP. However, gradual permafrost warming over recent decades, in addition to human impacts, has led to renewed high rates of subsidence and abrupt, rapid CY thermokarst processes.

\section{Keywords:}

Permafrost; Climate change; Holocene Thermal Maximum; Granulometry; Palaeolimnology; Ice complex; XRF; Eastern Siberia; Russia 
62 Global climate change results in higher temperatures and stronger climate variability in the northern high latitudes and permafrost-affected landscapes (Serreze et al., 2000; Serreze and Barry, 2011; IPCC, 2013; Fedorov et al., 2014a). Positive feedbacks are expected as temperatures warm due to greenhouse gas emissions from rapidly evolving thermokarst lakes and microbial decomposition of permafrost organic material (Walter Anthony et al., 2018), although during the Holocene, thaw lakes also served as carbon sinks (Walter Anthony et al., 2014). Hence, thermokarst lakes and thaw processes in ice-rich permafrost deposits are a crucial part of the global carbon cycle (Grosse et al., 2013; Olefeldt et al., 2016. Strauss et al., 2013, 2017). According to e.g. Stendel and Christensen (2002) the active layer (i.e. the seasonal thaw layer) thickness in the Northern Hemisphere will increase by $30 \%$ to $40 \%$ by the end of the $21^{\text {st }}$ Century. Regions with high ground-ice content, such as the Lena-Aldan interfluve in Central Yakutia (CY) (Soloviev, 1959, 1973), will therefore be particularly affected by high thaw and subsidence rates and the resulting ecosystem change (Fedorov et al., 2014b; Ulrich et al., 2017a). Thermokarst is the strongest permafrost degradation process in areas with high ground-ice content and results in a dissected landscape consisting of differentially aged thermokarst basins and lakes (Czudek and Demek, 1970; Tomirdiaro, 1982).

Thermokarst landscapes cover more than $60 \%$ of the ice-rich permafrost domain (Olefeldt et al., 2016). This coverage makes them a key player in permafrost ecosystems and highlights the importance of understanding these basins as a legacy of permafrost degradation after the Late Glacial Maximum (LGM). Regional thermokarst landscapes have been studied, and formative processes have been hypothesized by Soviet scientists using the example of CY thermokarst landscapes (e.g. Soloviev, 1973; Katasonov et al., 1979; Bosikov, 1998). Nevertheless, a knowledge gap remains and is addressed in this study by using spatially extensive sedimentological analyses to decipher Late Glacial to Holocene small-scale processes as well as related depositional and environmental conditions. The questions of how and when large thermokarst (lake) basins (i.e. alases; dry, grass-covered basins within the Taiga forest) were formed and how they evolved during the Holocene are still the subject of contemporary research (Pestryakova et al., 2012; Nazarova et al., 2013; Ulrich et al., 2017b); it is necessary to answer these questions in order to understand current and to predict future thermokarst processes.

Several studies of Late Glacial to Holocene thermokarst lake sediments have focused on northern and eastern Siberia (Andreev et al., 1997; Katamura et al., 2006, 2009; Popp et al., 2006; Biskaborn et al., 2013a,b, 2016; Schleusner et al., 2015; Klemm et al., 2016; see Fig 1a), 
94 Alaska (Farquharson et al., 2016; Lenz et al., 2016; Jongejans et al., 2018) and Canada (Lenz 95 et al., 2013; Fritz et al., 2018). The understanding of thermokarst processes is often linked to 96 their spatial distribution (e.g., Morgenstern et al., 2011) as well as to the sediment archives (e.g., 97 Morgenstern et al., 2013). Elucidating the sedimentary characteristics in combination with the 98 elemental composition and deduced biogeochemical properties (Bouchard et al., 2011, 2017; 99 Biskaborn et al., 2013b) is, moreover, important for understanding geomorphological 100 thermokarst processes. However, a statistical (i.e. manual) evaluation of polymodal grain size 101 distribution (GSD) according to e.g. Folk and Ward (1957) only allows limited interpretation 102 and discussion of sediment origin and transport conditions (Hartmann, 2007). But polymodal 103 GSDs are typical for natural sediments, in general, due to different sediment sources as well as 104 different transport and accumulation processes (e.g., Weltje and Prins, 2007), and typical of 105 postsedimentary treatments and ice-rich permafrost deposits of the Yedoma type, in particular, 106 due to their polygenetic origin (Schirrmeister et al., 2011a; 2013). A statistical analysis based 107 on the eigenvalues of a grain size dataset was therefore recognized as a promising approach 108 (e.g., Flemming, 2007). Endmember (EM) modeling is a widely used method for process109 oriented differentiation of multimodal GSDs (e.g., Weltje and Prins, 2003; Hamann et al., 2008; 110 IJmker et al., 2012; Dietze et al., 2014; Nottebaum et al., 2015) but it has very rarely been 111 applied to permafrost and in particular to thermokarst deposits so far (Strauss et al., 2012; 112 Klemm et al., 2016; Schirrmeister et al., 2017; Macumber et al., 2018). EM modeling uses the 113 eigenvalues of a dataset and reduces the dimensions of the data space by applying a factor 114 analysis method (Veganzones and Grana, 2008; Dietze et al., 2012). Finally, recurring patterns 115 in the source record are grouped into specific classes (i.e. EMs). The statistical method of 116 rEMMA thus offers meaningful genetic results to differentiate GSDs for reconstructing 117 sedimentological and paleoenvironmental conditions (Weltje and Prins, 2003, 2007; Dietze et 118 al., 2014; Dietze and Dietze, 2019).

119 By applying a multi-proxy approach in connection to rEMMA using ten sediment cores from 120 two thermokarst basins with different geocryolithological conditions, we aim to identify and to 121 interpret characteristic patterns in GSD and biogeochemical data of thermokarst deposits in 122 relation to age, location, geomorphology, and main depositional conditions of the different 123 drilling sites. The main objectives of this paper are (i) the lithostratigraphic characterization of 124 different kinds of thermokarst sediments using a multi-proxy approach and rEMMA; (ii) the 125 reconstruction of local geomorphological processes responsible for the individual development 126 of CY thermokarst basins during the Late Glacial and Holocene periods; and (iii) the detection 
127 of regional climatic imprints with respect to similarities in thermokarst development, 128 considering previous paleoenvironmental reconstructions in Siberia.

\section{$130 \quad 2$ Regional setting}

131 CY is bounded by the Lena and Aldan rivers and located in the east-Siberian Subarctic. The 132 region is a special case due to the lack of lowland glaciation during the late Pleistocene, a strong 133 continental climate setting, and continuous permafrost with depths reaching several hundred 134 meters (Fig. 1, Czudek and Demek, 1970). The active layer reaches depths of about $2.0 \mathrm{~m}$ in 135 grassland areas but has much lower depths below Taiga forest (e.g. Fedorov et al., 2014b).

136 Taliks (i.e. bodies of unfrozen ground) usually exist only below beds of major rivers and below 137 lakes where the water is deeper than winter lake-ice thickness. Isotherm subsurface 138 temperatures in the region at $10-15 \mathrm{~m}$ depth usually range from about $-3^{\circ} \mathrm{C}$ below dense forest 139 cover to about $-2^{\circ} \mathrm{C}$ below grassland areas (Fedorov et al., 2014b). The region is characterized 140 by low annual precipitation of $223 \pm 54 \mathrm{~mm}$ and a mean annual air temperature (MAAT) of $1419.8 \pm 1.8^{\circ} \mathrm{C}(1910-2014$ average at Yakutsk weather station, NOAA National Climatic Data 142 Center, http://www.ncdc.noaa.gov/, Station ID: GHCND:RSM00024959). With the exception 143 of stable Siberian anticyclones during winter time, the wind and weather conditions in CY are 144 determined by cyclonic weather conditions that run from west to east across the region. During 145 the winter period from September to May wind conditions are relatively calm. Slightly stronger 146 winds occur during the short summer period from June to August (Péwé and Journaux, 1983). 147 A 75-year record at Yakutsk indicates a mean annual wind velocity of $2.4 \mathrm{~m} / \mathrm{s}$ (Gavrilova, 1973). 148 For our study region, the Global Wind Atlas (2018) indicates an average wind speed of about $1494 \mathrm{~m} / \mathrm{s}$.

150 The Lena-Aldan interfluve region is a low-relief landscape. Geomorphological processes are 151 linked to Holocene and current thermokarst phenomena (Brouchkov et al., 2004; Katamura et 152 al., 2006; Fedorov and Konstantinov, 2009; Iijima et al., 2014; Séjourné et al., 2015; Ulrich et 153 al., 2017a, b). Thermokarst basins (i.e. alases) and thaw lakes are widespread, typical landscape 154 features in this region (e.g., Soloviev, 1973; Fig. 1b). Larch forest with inclusion of pine and 155 birch trees typically dominates the CY vegetation. Thermokarst basins form islands of 156 grasslands within the taiga forest that are dominated by steppe-like to swamp communities, 157 depending on edaphic factors within the basins (Mirkin et al., 1985; Desyatkin, 2008). 
158 Major parts of the Lena-Aldan interfluve region are covered by ice-rich fine-grained late 159 Pleistocene sediments containing up to $80 \%$ ice by volume, mainly in the form of huge 160 syngenetic ice wedges. These Yedoma deposits form the forest-covered Yedoma uplands 161 surrounding the thermokarst landscapes. Several terraces above the major rivers are 162 differentiated due to cryolithology and sediment genesis in the Lena-Aldan interfluve region 163 (Soloviev, 1959, 1973; Fig. 1c). Typical well-developed thermokarst basins and lakes in 164 different evolutionary stages are mainly found on the Tyungyulyu and Abalakh terraces. Both 165 terraces are characterized by thick ice-rich deposits (more than $40 \mathrm{~m}$ thick in some places) with 166 different cryolithological conditions and characteristics (Soloviev, 1959; Fedorov and 167 Konstantinov, 2003, 2009; Ulrich et al., 2017a).

168 Two thermokarst basins were chosen as study sites that were considered representative for the 169 respective terraces. Both are located about $80 \mathrm{~km}$ southeast from Yakutsk (Fig. 1c). The Khara 170 Bulgunnyakh (KB) alas (Lat: 61,836680, Long: 130,646150; Fig. 2a) is part of a larger alas 171 system and is located about $130 \mathrm{~m}$ a.s.l (above sea level) on the Tyungyuluy Terrace. The KB alas is about 1000 to $1500 \mathrm{~m}$ in diameter and about 6 to $10 \mathrm{~m}$ deeper than surrounding Yedoma 173 uplands. Three large pingos within the KB alas reach heights of 8 to $12 \mathrm{~m}$ and diameters of 50 174 to $100 \mathrm{~m}$. They are surrounded by very shallow lakes. The alas system was investigated by a 175 Russian research group in the 1970s (Katasonov et al., 1979). They suggest that its evolution 176 started around 12-10 thousand years ago because they found stalks of reed grass in the 177 northwest of the alas system below $3.0 \mathrm{~m}$ depth that has been dated to a ${ }^{14} \mathrm{C}$ age of $9120 \pm 200$ 178 yrs BP $(10,261 \pm 289$ cal yrs. BP).

179 The Yukechi (YU) alas (Lat: 61.764950, Long: 130.465260, Fig. 2b) is located on the Abalakh 180 Terrace at about $202 \mathrm{~m}$ a.s.1. The YU alas is about 300 to $500 \mathrm{~m}$ in diameter and about 10 to 15 $181 \mathrm{~m}$ deep. Two larger lakes and one small shallow pond existed within the alas. The area around 182 the YU alas is characterized by many young thermokarst features and lakes, indicating current 183 intensive thermokarst development. In particular, small, young thermokarst lakes are ubiquitous 184 on the Yedoma uplands. Many of these Yedoma lakes were evidently developed anthropogenically (e.g. in former agricultural areas) (Fedorov et al., 2014b; Ulrich et al., 2017a).

186 The YU alas and its surroundings have been monitored for several decades by the Melnikov 187 Permafrost Institute in Yakutsk (Bosikov, 1998; Fedorov and Konstantinov, 2003, 2008, 2009; 188 Fedorov et al., 2014b), but the exact timing and rate of YU alas evolution during the Holocene 189 remain unclear. 


\subsection{Permafrost coring and sampling}

193 At both study sites five cores were drilled in August 2013 from the dry basin ground (Fig. 2).

194 The drilling and sampling design follows a transect sampling design covering the major alas 195 landscape units (Fig. 3).

196 Thus, for each study site at least one to three cores were taken from the basin centers (KB3, 197 KB7, and YU2, YU3, YU4) and one or two cores from marginal basin areas (KB1, KB4, and 198 YU1). The KB7 core was taken on the top of a small pingo in the basin center. Several analyses 199 of KB7 core content including ostracods, chironomids, and pollen are already published (Ulrich 200 et al., 2017b). Addionally, at each study site one core was taken from the center of a neighboring 201 smaller drained thermokarst basin that is connected to the main basin (KB6, YU5).

202 If possible, an active layer pit was dug first and the frozen core was drilled from the permafrost 203 table. This was often necessary due to difficult drilling conditions within the active layer. 204 Sediment samples were then additionally taken from the active layer pit. Hereafter, they are 205 also discussed as part of the sediment cores. Data gaps especially within the active layer are the 206 result of core losses during drilling. All sediment cores were drilled down to $300-400 \mathrm{~cm}$ 207 below surface (bs). Each core segment (about $<20-30 \mathrm{~cm}$ long) was cleaned, described, and 208 photographed according to sediment composition, color, and cryolithological properties 209 following French and Shur (2010). Subsequently, the cores were continuously sampled at $<10$ 210 to $20 \mathrm{~cm}$ intervals, the samples were packed in plastic bags, and transported to the laboratories.

\subsection{Laboratory sedimentological and biogeochemical analyses}

213 We analyzed sedimentological and biogeochemical parameters for all sediment samples after 214 freeze-drying. For each analytical method, individual subsamples were used. Grain-size 215 analyses were carried out using carbonate-free (treated with 10\% HCL) and organic-free 216 (treated with $35 \% \mathrm{H}_{2} \mathrm{O}_{2}$ ) subsamples using a laser particle analyzer (Beckmann Coulter LS 200) 217 according to DIN ISO 11277. The proportions of sand, silt, and clay fractions are given as sums 218 between $2 \mathrm{~mm}$ and $63 \mu \mathrm{m},<63 \mu \mathrm{m}$ and $2 \mu \mathrm{m}$, and $<2 \mu \mathrm{m}$, respectively. Grain-size parameters 219 such as the geometric mean of the respective particle size distribution in $\mu \mathrm{m}$ and sorting in $\varphi$ 220 were determined according to Folk and Ward (1957) with the Gradistat software (Version 8.0, 221 Blott and Pye, 2001). The mass-specific magnetic susceptibility (MS) was analyzed using a 222 Bartington MS2B dual-frequency sensor. The values are expressed in SI units $\left(10^{-6} \mathrm{~m}^{3} \mathrm{~kg}^{-1}\right)$. 
223 Total carbon (TC) and total nitrogen (TN) were measured with a Vario EL cube elemental 224 analyzer and are given as weight percent (wt\%). The total inorganic carbon (TIC) content was 225 taken from carbonate measurements, which were conducted using the Scheibler method on an 226 Eijkelkamp Calcimeter apparatus by continuously adding 4 N HCL to a subsample until the $227 \mathrm{CO}_{2}$ outgassing reaction ceased. TIC is then calculated by dividing the percent calcium 228 carbonate $(\mathrm{CaCO} 3)$ with 8.33 . The total organic carbon (TOC) content was determined by 229 subtracting TIC from TC. The TOC/TN ratio is expressed as the quotient of TOC and TN 230 weight percentages but is given as mass ratio by dividing them by 1.167 (the ratio of atomic 231 weights of $\mathrm{N}$ and C; Meyers and Teranes, 2001). Stable carbon isotopes $\left(\delta^{13} \mathrm{C}\right)$ were measured 232 on carbonate-free subsamples with a Delta V Advantage isotope mass spectrometer 233 (ThermoFisher Scientific ${ }^{\mathrm{TM}}$ ) coupled with a ConFlo IV Interface and a Flash 2000 IRMS

234 Elemental Analyzer. The values are expressed in delta per mil notation $(\delta \%$ ) relative to the 235 Vienna Pee Dee Belemnite (VPDB) Standard.

236 Bulk samples from the recovered cores were analyzed according to Zielhofer et al. (2017) with 237 a Spectro Xepos XRF (X-ray fluorescence) device. For XRF sample preparation bulk 238 subsamples $(8 \mathrm{~g})$ were homogenized with a vibratory Retsch mill MM 200. Pressed pellets were 239 prepared using a Vaneox press at $20 \mathrm{t}$ for $2 \mathrm{~min}$. Measurements were conducted in a He 240 atmosphere.

241 According to Davison (1993), Bouchard et al. (2011), and Biskaborn et al. (2013a) only a few 242 elements can be used for tracking thermokarst processes. We chose the elements $\mathrm{Mg}, \mathrm{S}, \mathrm{Ca}$, $243 \mathrm{Mn}, \mathrm{Fe}$ and their ratios for detailed discussion of sediment properties and depositional 244 conditions and dynamics during thermokarst (lake) processes and basin evolution.

\subsection{Radiocarbon dating}

247 Radiocarbon dating was performed on 34 sediment samples from eight cores at the Curt248 Engelhorn-Centre of Archaeometry (Mannheim, Germany) using the Accelerator Mass 249 Spectrometer (AMS) technique (Tab. 1). The treatment was conducted with the Acid-Base250 Acid method and the samples were measured in the MICADAS accelerator. Hand-picked 251 terrestrial plant remains, wood fragments, and charcoal was dated only from 14 sediment 252 samples. For 20 samples soil organic carbon was dated using bulk sediment samples due to the 253 lack of organic macro remains within samples. Finally, the conventional ${ }^{14} \mathrm{C}$ ages were 
254 calibrated using the INTCAL13 data set (Reimer et al., 2013) and SwissCal 1.0 (L. Wacker, 255 ETH Zürich). The ${ }^{14} \mathrm{C}$ ages are normalized to $\delta^{13} \mathrm{C}=-25 \%$ (Stuiver and Polach, 1977).

$257 \quad 3.4$ Grain-size EM modeling and statistical analysis

258 The GSDs derived for each sample were used in an EM modeling approach to try and unmix 259 the polymodal GSDs into characteristic grain-size subpopulations which can be attributed to 260 sedimentary processes and conditions. EM modeling reduces the dimensions of a data space 261 (the GSDs) using the method of factor analysis, where eigenvalues are used to extract recurring 262 patterns in the initial data set (the EMs) (Veganzones and Grana, 2008). For rEMMA, the open 263 source R-package EMMAgeo following Dietze et al. $(2012,2014,2016)$ and Dietze and Dietze 264 (2019) was used, which contains the following steps: (1) Before conducting the actual EM analysis, a grain size data matrix is constructed, containing the grain size distributions 266 (columns) for each sample (rows), which is then rescaled to constant row sums. Then, a weight 267 transformation is applied according to Klovan and Imbrie (1971), using a weight transformation 268 parameter to yield a weight matrix that is not biased by variables with large standard deviations. 269 To allow the extraction of robust EMs, the ranges of the weight transformation parameter and 270 the minimum and maximum number of possible EMs are identified from the measured data set.

271 (2) EM modeling is performed for all combinations of the weight transformation parameter and 272 the number of EMs. Robust EMs (rEMs) are defined as grain-size subpopulations that appear 273 independent of the chosen model parameters and have an overall explained variance $>50 \%$. (3) 274 In order to quantify the uncertainties associated with the contribution of each grain size class to 275 each mean rEM, an uncertainty estimate is calculated from the spread of the contributing EM. 276 (4) The scores for each sample, which provide a quantitative estimate of how much a rEM 277 contributes to a sample, are calculated for the mean rEM loadings. An uncertainty estimate for 278 the scores is calculated via a Monte-Carlo simulation. From the rEM loadings and scores, 279 sample and class-wise explained variances are calculated to assess the overall quality of the 280 chosen model.

281 Finally, a principal component analysis (PCA) was performed on all rEM scores and sample 282 biogeochemical parameters to examine connections and relationships between sedimentology 283 and biogeochemistry of the thermokarst deposits. The PCA was carried out using R (R Core 284 Team, 2014). Because of the very different nature of the scores from the rEMMA and the 285 biogeochemical analyses, all variables were standardized by substracting the mean and scaling to the actual data range of the specific variable. Note that this means that variances are not equal 
to 1 for all variables. A four-fold cross validation approach was used to assess the number of

288 relevant PCs, using the R package missMDA (Josse and Husson, 2016). The resulting ordination diagram presents standardized metric scores and expresses the relationship among metrics as correlations. Additionally, all core samples are projected onto the ordination graph

291 for interpretation purposes only, because they do not affect calculations; sample scores on the 292 first and second principal component (PC1 and PC2, respectively) were plotted against core 293 depth.

\section{Results}

\subsection{Geochronology}

297 The results of dating 34 samples from eight cores shown in Table 1 indicate a clear difference 298 in age between bulk organic material and terrestrial organic macro remains. Overall, macro remain and bulk radiocarbon dates of YU study site samples are older than dates of KB site samples (Fig. 3). While almost all macro remains show middle to late Holocene ages, with the exception of two samples from cores YU3 and YU5, all bulk samples, except one sample from the YU2 core, were dated between Late Glacial and early Holocene ages (Tab. 1). This age discrepancy is attributed to the different carbon sources of the dated material and will be independently considered in further geochronological discussions. Since there is a very low TIC content in all cores ( 0.1 to $1.7 \mathrm{wt} \%$, Appendix A), carbonate-derived reservoir effects are suggested to be insignificant.

307 For the KB study site, macro remain ages from the central basin have been derived only for the 308 KB7 core. The five KB7 macro remain samples taken between 320 and $60 \mathrm{~cm}$ bs show middle 309 Holocene radiocarbon dates between $6582 \pm 78$ and $5752 \pm 102$ cal. yrs. BP (see also Ulrich et al., 2017b). For the KB1 core at the basin edge, three late Holocene macro remain ages range 311 between $3314 \pm 62$ and $1812.5 \pm 72.5$ cal. yrs. BP (between 243 and $125 \mathrm{~cm}$ bs, respectively). 312 One sample $(92 \mathrm{~cm} \mathrm{bs})$ of the KB6 core located centrally within the small drained basin 313 orginated from an organic inclusion with wooden remains and was dated to $3316 \pm 61$ cal. yrs. 314 BP. The late Pleistocene and Late Glacial to early Holocene bulk ages for the KB study site generally decrease from the basin center (KB3, KB7) to the basin edge (KB1) (Tab. 1). The

316 KB3 core show the highest ages at the KB study site and continuously upward decreasing bulk ages between $38,355 \pm 615$ and $12,902.5 \pm 184.5$ cal yrs BP. 
318 For all YU study sites, five radiocarbon dates were derived from macro remain samples. Two samples from the basin's center (YU3) show ages of 34,865 235 cal. yrs. BP at $185-170 \mathrm{~cm}$ bs and $3975 \pm 102 \mathrm{cal}$. yrs. BP at 40-36 cm bs. One macro remain sample from the YU1 core (110$105 \mathrm{~cm}$ bs) at the basin edge was dated to $4606 \pm 175 \mathrm{cal}$ yrs. BP. Another two samples from the YU5 core of the small drained neighboring basin (Figs. 2b and 3) show strong differences: While the macro remain sample from $222-210 \mathrm{~cm}$ bs was dated to the late Pleistocene time period (39,340 \pm 650 cal. yrs. BP) and thus represents the oldest macro remain sample from both study sites, another sample from $40-20 \mathrm{~cm}$ bs shows a modern age but may have been contaminated during drilling, which is even more probable considering the bulk sample age from same depth (see Tab. 1). The YU bulk ages show a rather unclear division between the central and the marginal parts of the basin (Tab. 1). Late Pleistocene to middle Holocene bulk ages are shown by the basin center cores YU3 and YU2, while the dates from the lower part of the YU1 core at the basin edge show a strong inversion of downward decreasing Late Glacial ages. This probably indicates the strong redeposition of Yedoma deposits during the lateral expansion of the thermokarst basins (see discussion below). The YU5 core from the neighboring small basins, however, shows continuously upward decreasing late Pleistocene bulk ages between $41,625 \pm 405$ and $27,625 \pm 165$ cal yrs BP.

\subsection{Cryolithology, Sedimentology, and Biogeochemistry}

As a result of our laboratory analysis of sedimentological and biogeochemical parameters, we indentify different facies within the thermokarst deposits from the basin edges and from the central basin parts, which will be described separately for each study site. Generally, all KB and YU sediment sequences were composed of visibly homogeneous silt-dominated deposits with varying but generally low amounts of organic inclusions and varying ice contents (Fig. 4). Usually, the upper half of all sediment cores was characterized by rust-stained brownish-greyish deposits. These horizons generally continued downwards in the frozen core material with some blackish streaky layers and spots (Fig. 4a-f). The lower frozen parts of the cores were usually dominated by dark grey to dark olive-green sediments, interrupted by blackish spots and streaky layers (Fig. 4g-1), which were less pronounced within the YU cores. Furthermore, sediment layers in the basin edge cores (KB1 and YU1) showed bent or mixed layers in relation to topography changes on the thermoterraces (Fig. 3).

349 The ground-ice content often increased with depth and was represented by parallel to nonparallel lenticular-layered to reticulate cryostructures, which reached a thickness of up to $6 \mathrm{~mm}$ 
in some deeper core parts (Fig. 4). Exceptions here were represented by the cores from the neighboring small basins (KB6 and YU5). They showed significantly lower ice content and fewer to no cryostructures in their frozen parts. In addition, all cores from the YU basin center (YU2, YU3, YU4) were unfrozen. This is due to an existing talik below the YU alas. Postcryogenic structures in the lower core parts show once-frozen, ice-rich sediments. In particular, the YU2 core is currently strongly influenced by ground water changes due to the nearby lake and showed pronounced redox properties in the sediment (Fig. 4a).

The KB thermokarst deposits are composed of uni-, bi-, tri-, and polymodally distributed, poorly to very-poorly sorted, very-fine to fine sandy medium-to-coarse silt. The grain-size characteristics differ between the horizons of a core as well as between the drilling sites (Fig. 5). The GSDs and MS values of the KB3 core from the basin center show little variability (Fig. 6). The KB3 GSDs are bimodal with main peaks in the coarse silt fraction. The second mode can be found in the coarse clay to very-fine silt. The grain-size mean for the KB3 core is $16.7 \pm 1.1 \mu \mathrm{m}$ (see Appendix A, Table S3). GSD peaks of the KB7 core from the small pingo top are located mainly in the coarse-silt fraction, but all samples show high variability (mean $25.2 \pm 6.8 \mu \mathrm{m}$; Tab. S4). Additional minor but distinct peaks in the fine-sand fraction are mainly found in samples from the upper and lower KB7 profile, while minor peaks in the coarse clay to very-fine silt fraction are predominantly found in the middle of the core. The MS decreases upwards ( 0.3 to $\left.1.3 \times 10^{-6} \mathrm{~m}^{3} \mathrm{~kg}^{-1}\right)$ with a distinct peak of $2.2 \times 10^{-6} \mathrm{~m}^{3} \mathrm{~kg}^{-1}$ at $285-258 \mathrm{~cm} \mathrm{bs}$. The GSDs of the KB1 and KB4 basin edge cores show main peaks in the coarse silt fraction with generally two minor peaks in the fine sand and clay fractions (Fig. 5). The grain-size means for KB1 and KB4 are 23.5 $\pm 5.8 \mu \mathrm{m}$ and $18.0 \pm 2.0 \mu \mathrm{m}$, respectively (Tabs. S1 and S2). Increased amounts of sand in the upper and lower KB1 profile and in the upper KB4 profile correspond to increased MS values. The GSDs of the KB6 core from the neighboring smaller basin also show high variability with a grain-size mean of $23.3 \pm 8.7 \mu \mathrm{m}$ (Tab. S5) and main peaks in the coarse silt fractions. MS values show comparably less variability, slighty decreasing upwards (1.2 to $\left.0.6 \times 10^{-6} \mathrm{~m}^{3} \mathrm{~kg}^{-1}\right)$.

The KB biogeochemical records and elemental composition show some pronounced differences in relation to the sedimentation history and geomorphological location of the individual sediment profiles. With the exception of the KB7 core, the TOC values of all cores are comparably low with hardly any variations. In contrast, the upper half of the KB7 core shows 
upwardly increasing TOC values that reach a high value of $10.1 \%$ at the active layer bottom (Fig. 6; mean 3.6 $\pm 2.9 \%$ ). The variations of TOC/TN ratios are higher for the $\mathrm{KB}$ basin edges (KB1: 7.9 - 14.0, KB4: 6.6 - 15.1) than for the basin centers (KB3: 6.3 - 11.2, KB7: 7.1 - 10.5) and the KB6 core in the small neighboring basin $(5.8-8.6)$. The $\delta^{13} \mathrm{C}$ values are, however, homogeneous for KB3 (-25.4 to $-24.4 \%$ ) and KB1 (-25.1 to $-24.1 \%$ ) and show little variation in KB4 (-26.2 to $-24.1 \%$ ), but the values are lower and upwardly decreasing in KB7 (-28.8 to $-25.4 \%$ ) and $\mathrm{KB} 6\left(-27.2\right.$ to $-24.5 \%$ ). The $\mathrm{CaCO}_{3}$ content is strongly negatively correlated with the $\mathrm{Ca} / \mathrm{Mg}$ ratio in all $\mathrm{KB}$ core profiles, indicating that $\mathrm{Ca}$ is largely bound as $\mathrm{CaCO}_{3}$. $\mathrm{CaCO}_{3}$ concentration shows relatively strong variations and several pronounced peaks were found in all cores which ranged between 0.0 and $7.4 \%$ with highest values reached in the lowest parts of KB7 and KB3 (basin center) and the middel core parts of KB4 (basin edge). Strong differences between the coring locations and within the cores can be seen in the S contents of the KB cores (Fig. 6). Usually, peaks in S contents coincide with the above-described black layers and spots in the middle and lower parts of the KB sediment cores. With the exception of $\mathrm{KB} 7$, the $\mathrm{Fe} / \mathrm{S}$ ratio is low in the frozen core parts but increases strongly in the active layer of all $\mathrm{KB}$ cores. The $\mathrm{KB} 7$ core, however, shows a very narrow $\mathrm{Fe} / \mathrm{S}$ ratio, but the ratio is higher at the profile bottom and decreases upwards with two small peaks at 258-143 cm bs and at 70-30 $\mathrm{cm}$ bs. The Fe/Mn ratio shows strong variation in the KB1 and KB4 basin edge cores and the KB3 basin center core. Variations are smaller in KB6 and the ratio increases stepwise in KB7.

\subsubsection{Sedimentological and biogeochemical results from the YU basin}

The GSDs of YU thermokarst basin deposits are differentiated within and between the cores, similar to the KB results (Fig. 5). The GSDs of the YU2 core from the lowest part of the basin center show variations with bimodal distributions, main peaks in the coarse silt fraction, and secondary modes in the coarse clay to very-fine silt. The grain-size mean is the lowest of all cores at $15.4 \pm 1.5 \mu \mathrm{m}$ (Tab. S7). The grain-size mean and GSD variability is a little higher for the other basin center cores YU3 and YU4; 17.3 $\pm 3.5 \mu \mathrm{m}$ and 19.8 $\pm 3.9 \mu \mathrm{m}$, respectively (Tabs. S8 and S9). Both cores, moreover, show main peaks in the coarse silt fraction, with generally minor peaks in the fine sand and clay fractions. However, the YU3 GSD variability is determined by a few sandy samples and mostly stronger secondary modes in the coarse clay

414 fraction, while the YU4 GSDs are characterized by more distinct secondary modes in the fine sand fraction. Besides a strong decrease in the upper part of core YU2, the MS shows little variation in the basin center sediments. The GSDs of the YU1 core from the thermoterrace at 
the basin edge show high variability from uni- to polymodal distributions with main peaks in the coarse silt fraction and fluctuating secondary peaks in the fine sand and coarse clay to fine silt fractions (Fig. 5). The grain-size mean is 21.1 $\pm 5.9 \mu \mathrm{m}$ (Tab. S6). Similar to the KB basin edges, increased amounts of sand in the upper and lower part of YU1 correspond to increasing MS values. Compared to the KB6 core, the YU5 core from the neighboring small drained basin shows little GSD variabilty. The lower half of the YU5 core is characterized by higher amounts of fine sand while the upper half shows higher clay contents. The grain-size mean is $19.0 \pm 3.0$ $\mu \mathrm{m}$ (Tab. S10).

The biogeochemistry of the YU sediments shows some differences from the KB thermokarst basin deposits (Fig. 7). The TOC content in the YU basin is higher on average than in KB. TOC increases upwards from $0.5 \%$ to $4.0 \%$ in the uppermost part within the basin edge core YU1. In the basin center, YU3 shows lower downward increasing values between 0.3 and $1.3 \%$. The TOC content peaks in the uppermost part of YU2 to $2.3 \%$ and increases slightly downwards in the YU4 core, ranging between 0.3 and $2.6 \%$. The YU5 core TOC content is more stable, ranging between 1.3 and $2.5 \%$. The variations of the TOC/TN ratio are generally less at the YU study site than at the KB study site. But similar to KB, variations are larger at the basin edge (YU1: 5.6 - 11.2) than in the center area of the YU basin (YU2: 7.2 - 9.6; YU3: 6.2 - 8.3; YU4: 6.0 - 8.5). The ratio, however, increases slightly upwards in the YU5 profile $(6.6-10.0)$. The $\delta^{13} \mathrm{C}$ values are homogeneous in all cores, averaging around $-25 \%$. Only the uppermost part of core $\mathrm{YU} 2$ shows a strong decrease of $\delta^{13} \mathrm{C}$ to $-29.2 \%$. Similar to $\mathrm{KB}$, the $\mathrm{CaCO}_{3}$ content in the $\mathrm{YU}$ cores is negatively correlated to the $\mathrm{Mg} / \mathrm{Ca}$ ratio. However, the $\mathrm{CaCO}_{3}$ content is higher on average in YU cores than in KB cores, ranging between 0.8 and $13.8 \%$ (Fig. 7). With the exception of the YU5 core, the S contents are on average lower in the YU than in the KB sediment sequences and differences between basin center and edge are smaller, but some variations within the YU cores are obvious as well. The higher average TOC content at the YU site and the generally stronger correlation of the S contents with TOC as well as the visible absence of significant black streaks in YU sediments suggest that there is a larger amount of organically bound $\mathrm{S}$ within the $\mathrm{YU}$ sediment sequences. The Fe/S ratio shows a different behavior within the YU sediment sequences than within the KB cores. Within the basin center, the $\mathrm{Fe} / \mathrm{S}$ ratio is narrower and shows less variation in the YU3 core but shows an upwards increase and higher ratios in the YU2 and YU4 cores with a strong peak at about 80 to $100 \mathrm{~cm}$ bs; the Fe/S decreases again towards the surface. For YU1 at the basin edge, the Fe/S ratio shows a little more variation with wider ratios in the upper middle core part. The $\mathrm{Fe} / \mathrm{S}$ ratio is 
sequences shows less variation than in the KB sequences, but variations are generally largest in YU1 at the basin edge and smallest in core YU5.

\section{3 rEMMA}

455

The four final rEMs account for $79.5 \%$ of the total variance of all initial variables (i.e. all input GSDs) with modes in various grain-size fractions between clay and medium sand. The unmixed rEMs are characterized by their loadings (Fig. 8). The rEM1 shows its strongest peak in the coarse clay to very-fine silt fraction $($ mode $=2.9 \mu \mathrm{m}$, explained variance $(\mathrm{EV})=24 \%)$. $\mathrm{rEM} 1$ exhibits some unmixed residuals in the coarse silt and fine sand fraction. rEM2 has a bimodal distribution with residual mode in the fine sand fraction. The main mode is located in the medium to coarse silt fraction at $27.4 \mu \mathrm{m}(\mathrm{EV}=18 \%)$, but its slightly left-skewed distribution shows some tendency to increased finer grain sizes. rEM3 shows a distinct unimodal distribution with a high peaked mode in the coarse silt fraction at $39.8 \mu \mathrm{m}(\mathrm{EV}=25 \%)$ but it shows some tendency to the coarser grain sizes by a slightly right-skewed distribution. The mode of rEM4 peaks in the fine to medium sand fraction at $176.8 \mu \mathrm{m}(\mathrm{EV}=32 \%)$ with some tendency towards the finer grain sizes. The class-wise explained variance in Fig. 8 shows that in particular the very-fine to fine-grained fractions show highest variances.

468 Calculated mean scores are shown in Fig. 8 with their confidence intervals and in Fig. 9 against 469 depth for each core individually. The scores represent the relative rEM contribution to each 470 sample, i.e. how each sample is composed of a specific rEM. Equal compositions of mostly 471 rEM1, rEM2, and rEM3 with comparatively larger shares of rEM1 and rEM2 over the entire 472 sediment sequences are reflected in particular for the basin centers (i.e. KB3, YU2, YU3). An 473 exception is shown by the KB7 scores, which exhibit strong variations of all rEMs but generally 474 a division of the sediment sequence. While rEM3 and rEM4 dominate the lower half of the KB7 core, the shares of rEM1 and rEM2 are significantly higher in the upper half. The basin edge sediment sequences (i.e. KB1, KB4, YU1) show varying compositions including all rEMs.

477 Smaller contribution of rEM1 in KB1 and YU1 emphasize the proximal accumulation 478 conditions of these sites and the increased influence of coarser basin slope sediments. The 479 higher contribution of rEM1 in the KB4 basin edge core are a sign of comparatively lower erosion at the northern edge of the KB basin than at the eastern edge captured by the KB1 core 481 (Figs. 2 and 3). In contrast, the larger shares of rEM3 and rEM4 in the middle part of the YU4 basin center core (Fig. 9) are probably related to YU4's location at the edge of a flat hill within 483 the YU bottom. The KB6 and YU5 rEM scores show the individual rEM compositions within 
the neighboring small drained basins. KB6 shows a bulge increase and subsequent decrease of rEM1 und rEM2 in the lower half of the sequence. The upper half shows stronger variations of all rEMs. YU5, on the other hand, is dominated by a homogeneous share of rEM1, rEM2, and rEM3, but also shows higher amounts of rEM4 in three samples from the lower part of the core.

\subsection{PCA}

The PCA shows two major principal components (PC1 and PC2) that explain 27.9\% and 22.3\%, respectively, of the total variance of all $\mathrm{rEMs}$ and biogeochemical parameters from the $\mathrm{KB}$ and YU thermokarst deposit core samples (Fig. 10). PC1 is positively correlated with rEM1, rEM2, and Fe/Mn and negatively correlated with rEM3, rEM4, and MS. PC2 is clearly controlled only by the biogeochemical parameters; it shows positive correlations with $\mathrm{S}, \mathrm{TOC}, \mathrm{Mg} / \mathrm{Ca}$, and $\mathrm{TOC} / \mathrm{TN}$, and negative correlations with $\delta^{13} \mathrm{C}, \mathrm{Fe} / \mathrm{S}$, and $\mathrm{CaCO}_{3}$. The core samples projected into the ordination graph show only rough separations. The basin edge core samples (KB1, KB4, YU1) are scattered throughout the complete PC1 axis but are more common on the negative part of the PC2 axis, while the basin center core samples (KB3, YU3) occur more frequently on the positive part of PC1 but more evenly throughout the complete PC2 axis. The YU2 core samples are clustered in the lower right of the ordination plot and the KB7 core samples are broadly scattered on the positive part of the PC2 axis and across the complete PC1 axis. The core samples from the neighboring small basins, KB6 and YU5, as well as the YU4 core sample are scattered across both PC axes.

504 While PC3-PC5 are considered relevant due to the results of the four-fold cross validation 505 approach, a reasonable physical interpretation is not possible. Ordination plots for all PCs are included in the supplement material (Appendix B, Figs. S1, S2, and S3).

\section{Discussion}

5.1 Sedimentary properties and biogeochemical characteristics of CY thermokarst deposits

510 The GSDs and the resulting sorting provide information on the erosion and transport processes 511 as well as on the accumulation conditions of the thermokarst sediments. Assuming that

512 individual transport processes would have led to better fractionation of the grain sizes (e.g., 513 Folk and Ward, 1957), the poor to very poor sorting of all GSDs indicates short transport paths 514 (see Appendix A) or a mixture/overlay of different formation processes (Blott and Pye, 2001). 
515 The subsequent reconstruction of erosion, transport, and sedimentation conditions is thus 516 difficult to perform (Dietze et al., 2012, 2014; IJmker et al., 2012). In the study region, the 517 GSDs of the source sediments from Yedoma deposits are heterogeneous due to their 518 polygenetic formation, leading to polymodal GSDs (Schirrmeister et al., 2011a, 2017; Strauss 519 et al., 2017). The spatial understanding of the local Yedoma structure is thus of great importance 520 for interpreting GSDs in thermokarst deposits (see section 5.2).

521 In general, coarser grain sizes (especially the fine sand fraction) within the thermokarst (lake) 522 basins point to shorter transport paths after erosion processes along lake shores. Coarser-grained 523 sediments can also be accumulated via longer high-energy transport or by subsidence and in 524 situ accumulation close to the lake center within small thermokarst lake basins. Finer grain sizes 525 like coarse clay are thought to be indicative of distal (to the lake center) transport in larger lakes 526 (e.g. Biskaborn et al., 2013b).

527 Generally, the MS parameter depends on source rock and/or sediment (Schirrmeister et al., 528 2011b). We found stronger MS signal variations especially in the basin edge sediments from 529 both study sites (KB1, KB4, YU1) and the lower part of the KB7 core.The reworking of 530 Yedoma deposits under lacustrine conditions may have altered the MS signal in the basin 531 centers, since the magnetizable minerals degrade under reducing conditions, resulting in lower 532 values (Evans et al., 1997; Hanesch and Scholger, 2005). The MS signal therefore also indicates 533 an increase in lacustrine finer-grained detritus (lower MS) or increased terrestrial coarser534 grained input (higher MS) (Matasova et al., 2001). In accordance with Schirrmeister et al. 535 (2011c), we also observe that the MS is inversely proportional to the sediment TOC.

536 The TOC proportion is a main parameter in the analysis of thermokarst sediment developmental 537 history (e.g., Walter et al., 2007; Lenz et al., 2016; Bouchard et al., 2017). Assuming constant 538 input, high TOC values in ice-rich permafrost deposits generally reflect low organic matter 539 degradation during the past and high quality in the sense of future microbial degradation 540 (Strauss et al. 2015). This is generally typical for polar regions, as microbial decomposition of 541 organic matter has limited amount of time before freezing, thus it generally ceases at low 542 temperatures and organic matter is preserved for a long time in the frozen state (Strauss et al., 543 2013, 2017). Generally, we measured comparably low TOC values in the KB and YU alas 544 thermokarst deposits, suggesting low organic carbon input or strong post-sedimentary organic 545 carbon decomposition, at least within the drilled $300-400 \mathrm{~cm}$ bs. Based on the fact that there 546 is no depth-dependent trend in some cores, we assume a relatively low organic carbon input 547 compared to other thermokarst and Yedoma landscapes (Strauss et al., 2013). The exceptionally 
548 high TOC values in the upper half of the KB7 profile are suggested to be related to high 549 bioproductivity and a nutrient oversupply within a very fast-growing thermokarst lake during 550 the mid-Holocene at this specific site (Ulrich et al., 2017b).

551 Organic carbon transport pathways (e.g. lacustrine or terrestrial) into the formerly existing 552 thermokarst lake can be identified by combined analysis of $\delta^{13} \mathrm{C}$, the TOC/TN ratio, and TOC 553 (e.g. Meyers and Teranes, 2001). High TOC/TN ratios around 20 are produced by cellulosic, 554 low-protein, vascular land plants. In contrast, narrow TOC/TN ratios between 4 and 10 are 555 produced by phytoplankton or algae (Meyers, 1994; Meyers and Lallier-Vergès, 1999). Ratios 556 between these very high and very low values as shown in our data can be seen as a mixture of 557 different entry paths. However, especially in oligotrophic lakes, the TOC/TN ratio can be 558 reduced by organic matter decomposition under oxic conditions, because carbon is preferred 559 over nitrogen (Meyers and Lallier-Vergès, 1999; Meyers and Teranes, 2001). For the 560 thermokarst deposits studied here, higher TOC/TN values have been interpreted as greater 561 terrestrial input, whereas lower values have been considered as greater lacustrine input and/or 562 post-sedimentary carbon decomposition (Meyers, 1994; Biskaborn et al., 2013b; Lenz et al., 563 2013).

564 The $\delta^{13} \mathrm{C}$ values provide information about plant metabolism because sedimentary organic 565 matter $\delta^{13} \mathrm{C}$ values are generally very similar to those of the parent vegetation and post566 sedimentation of carbon isotopes is therefore negligible (O'Leary, 1981; Melillo et al., 1989). 567 Thus, we interpreted very low values as an indication of increased bioproductivity. This is 568 obvious in the upper part of the KB7 and YU2 profiles. Finally, different sedimentation milieus 569 can be derived from the TOC/TN- $\delta^{13} \mathrm{C}$ relationship (Fig.11), which reflects organic matter 570 origin (e.g., Meyers and Teranes, 2001). This relationship shows a shift from lacustrine algae 571 to terrestrial plants in several samples from the KB1 and KB4 basin edge cores as well as within 572 the lower and upper part of the YU1 core and with decreasing profile depth in the YU5 core. 573 Otherwise the $\mathrm{TOC} / \mathrm{TN}-\delta^{13} \mathrm{C}$ relationship suggests mainly lacustrine sediment origin for great 574 parts of the KB and YU drilling locations (Fig. 11).

575 S together with phosphorus (P) contents can be used as a proxy for organic entry in thermokarst 576 (lake) deposits (Bouchard et al., 2011). The P content, however, shows only weak correlations 577 with the TOC in our drilled sediments and little variations (see Appendix A). The S content 578 show more connections to TOC but higher S contents also often corresponds with black streaks 579 and spots, especially in the KB sediment sequences. These streaks are interpreted as iron sulfide 580 (FeS) precipitation by iron hydroxide reduction. This is bacterially mediated under anoxic 
conditions in relatively shallow warm waters and can therefore be seen as evidence of reducing conditions (Siegert, 1979, 1987; Biskaborn et al., 2012). Since the streaks and spots do not follow stratigraphic boundaries, the precipitation of this compound is considered to be postsedimentary.

$585 \mathrm{CaCO}_{3}$ can reach the lacustrine sediment archive via several paths. Generally, biogenic and 586 geogenic carbonate origin can be differentiated. The biogenic part is usually formed by aquatic invertebrates like molluscs or ostracods in thermokarst lakes (e.g., Wetterich et al., 2005, 2008).

588 Geogenic formation in CY thermokarst deposits is probably the result of authigenic origin in 589 Yedoma deposits, which are usually rich in carbonate (Katasonov et al., 1979; Schirrmeister et 590 al., 2011a). Furthermore; the original mineral supply to growing thermokarst lakes in ice-rich 591 areas such as the Lena Aldan interfluve may be greater than in areas with lower ice contents 592 (Pestryakova et al., 2012). The $\mathrm{Mg} / \mathrm{Ca}$ ratio in connection with $\mathrm{CaCO}_{3}$ (geo- and biogenic) 593 provides estimations not only about lake level changes (Haberzettl et al., 2007) but also lake 594 temperature, salinity, and photosynthetic activity during summer months. Generally, higher $595 \mathrm{Mg} / \mathrm{Ca}$ ratios and lower $\mathrm{CaCO}_{3}$ values in the studied thermokarst deposits were interpreted to 596 reflect higher lake level and vice versa. For instance, $\mathrm{CO}_{2}$ is often withdrawn from lake water 597 during summertime due to increased water temperatures and photosynthesis, thus shifting the $598 \mathrm{CO}_{2}$ equilibrium at $\mathrm{pH}$ values around 8 (typical for current thermokarst lakes in the Lena Aldan 599 interfluve region; Pestryakova et al., 2012) towards insoluble $\mathrm{CaCO}_{3}$, increasing the $\mathrm{Mg} / \mathrm{Ca}$ 600 ratio (e.g., Ji et al., 2005; Liu et al, 2008). Opitz et al. (2013) discussed high carbonate content 601 in lacustrine sediments of a thermokarst system on the Tibetan Plateau as an indicator of 602 shallow lake levels with corresponding ostracod associations. However, high sediment 603 carbonate content despite the absence of ostracods suggest also decreasing lake levels and 604 increasing salinity due to high evaporation (Liu et al., 2008; Wetterich et al., 2008; Ulrich et al., 605 2017b).

606 The Fe/Mn ratio is generally used to evaluate redox conditions in thermokarst lakes (Bouchard 607 et al., 2011, 2014; Biskaborn et al., 2013b). Since Mn is mobilized faster than Fe under anoxic 608 conditions, Fe accumulates residually under reducing conditions (e.g. Davison, 1993). During 609 sedimentation, this ratio is stored and thus preserved as an indicator of the redox milieu during 610 sediment deposition into the lacustrine archive. Increasing Fe/Mn values are thus interpreted as 611 indicative of a change to reducing limnic conditions during sediment accumulation. According 612 to Bouchard et al. $(2011,2014)$ those anoxic hypolimnic conditions are typical in thermokarst 613 lakes. In contrast, narrow Fe/Mn ratios indicate oxidizing conditions. According to Biskaborn 614 et al. (2013b), these are usually present in shallow waters or better-oxygenated marginal areas 
615 of thermokarst lakes. Strong variations in the Fe/Mn ratio as seen in particular in the KB 616 sediment sequences thus suggest continuously changing redox conditions during sedimentation 617 at this location, which indicates either a change in lake level or a change between lacustrine and 618 terrestrial depositional conditions.

619 The Fe/S ratio was additionally used for qualitative estimations of thermokarst (lake) basin 620 sediment oxygenation. Lenz et al. (2016) discuss increasing Fe/S ratios in relation to increasing

621 lake water oxygenation as being due to increasing water depth and lake size for a thermokarst 622 lake in northern Alaska. They also suggest a relationship between lake-ice cover during 623 wintertime and decreasing Fe/S ratio; reduced water volume over lake sediments favors anoxic 624 conditions, in particular in the near-shore lake zone. The $\mathrm{Fe} / \mathrm{S}$ ratio is also higher in relation to 625 terrestrial sediment deposition (Lenz et al., 2016), but in light of the data presented here it also 626 seems to increase after lake drainage or water loss and active layer oxygenation.

629 Overall, the thermokarst deposits at both study sites have been transported and deposited in situ 630 with the Yedoma deposits as source sediment. In particular, the dating of the bulk organic 631 material suggests that there was no remarkable additional sediment input from other sources 632 than the Yedoma deposits during thermokarst evolution at the study sites. For instance, greater 633 Holocene dust entry into the CY thermokarst (lake) basins has not been proven so far. There is 634 still a knowledge gap concerning past wind pattern in the CY region. This is likely connected 635 to the fact that modern wind conditions are relatively calm throughout the year due to the highly 636 continental climate (see section 2). Similar conditions probably existed in East Siberia 637 throughout the Pleistocene/Holocene (Zimov et al., 1995). However, the polygenetic 638 provenance of the Yedoma source sediments is suggested to be partly influenced by aeolian 639 transport beside mainly proluvial, alluvial, fluvial transport, and lacustrine deposition (Soloviev, 640 1959; Katasonov and Ivanov, 1973; Schirrmeister et al., 2013). Péwé and Journaux (1983) even 641 discuss a dominant eolian component of silty Yedoma deposits in CY.

642 However, the depositional activities during thermokarst (lake) development overprinted the 643 original depositional processes of the Yedoma source sediments. The final rEMs are therefore 644 the result of the grain size fractionation during thermokarst development. With the rEMMA we 645 were able to detect and to discuss them as single-endmembers, which is hardly possible from 646 the classical measures of grain size properties (Dietze and Dietze, 2019). The rEMMA 
presented here has yielded four final rEMs (Fig. 8). In general, the final rEMs can be assigned

648 to specific processes, allowing specific sediment transport and accumulation pathways during 649 thermokarst development to be identified (Table 2). The mean scores of the studied core 650 samples (Fig. 9) show the internal variability and thus the sediment history of each sediment 651 sequence taken from different geomorphological sites within the thermokarst basins. Generally, 652 the scores show that the internal variability of basin centers is rather low compared to that of 653 basin edges and the small neighboring basins.

\subsubsection{Distal transport dynamics}

656 The rEM1 shows a very coarse-grained clay to very-fine silt. Thus, rEM1 is assigned to a (long) 657 distal transport or a low-energy sedimentation milieu under generally lacustrine conditions 658 (Table 2). In particular, the pronounced rEM1 and the high class-wise explained variance in the 659 range of the very fine particle sizes (Fig. 8) seem to be characteristic for CY thermokarst 660 deposits, and can therefore be used as a distinctive mark to distinguish these from Siberian 661 Yedoma deposits that show less pronounced or absent EMs in the clay fraction of comparable 662 EM analyses (Strauss et al., 2012; Schirrmeister et al., 2017). The rEM2 and rEM3 show silty 663 GSDs. These are background sedimentation signals, since the initial polymodal GSDs of 664 Yedoma deposits are mainly characterized by silty grain sizes (Soloviev, 1959; Schirrmeister 665 et al., 2011a). By comparison, rEM2 tend to have finer grain sizes, whereas rEM3 tend to have 666 coarser grain sizes. Based on the proportion of rEM2 and rEM3 in an individual thermokarst 667 sediment sequence (Fig. 9), it is possible to deduce the sedimentation milieu; rEM2 indicates 668 more distal transport or lower-energy conditions, whereas rEM3 indicates more proximal 669 transport or higher-energy conditions.

\subsubsection{Local transport and in situ accumulation processes}

672 At both study sites, rEM4 shows a strong influence of fine sand, which is also contained in the 673 CY Yedoma deposits (Strauss et al., 2012; Schirrmeister et al., 2017). Thus, rEM4 (together 674 with rEM3) is interpreted as an indicator of very short transport pathways and/or in situ 675 accumulation of source sediments during thermokarst initiation. The former occurs especially 676 in the immediate vicinity of eroding lake shores (Table 2). 
679 During lake bank erosion, coarser components accumulate at the shores, while the finer grain 680 sizes can be transported to the lake basin center, resulting in grain size fractionation (Biskaborn 681 et al., 2013b). This requires a corresponding lake size, which can be assumed from the rEM 682 score of the KB3, YU2, and YU3 cores (Figs. 2 and 9). With the exception of these core 683 locations, the variations in rEM scores within all sediment cores show alternating homogeneous 684 and heterogeneous fractionation phases, suggesting that a clear sedimentological relationship 685 between a former lake center and corresponding lake shore areas of a single growing 686 thermokarst lake in each basin are difficult to detect at both study sites. This suggests that 687 sedimentary characteristics represent depositional environments of many smaller thermokarst 688 lake basins, which are characterized by changing water levels, poorer sediment fractionation, 689 and changing erosion and thermokarst activities. This is seen in rEM scores from the small 690 neighboring basins (KB6 and YU5) and the small pingo (KB7), in which lacustrine phases that 691 are associated with the dominance of fine-grained sediment accumulation (rEM1 and rEM2) 692 alternate with accumulation phases of coarser sediment (rEM3 and rEM4), probably originating 693 by lateral lake basin expansion and erosive shore processes (Biskaborn et al., 2013b; Lenz et 694 al., 2013). The core locations in the first case became more distal to the sediment source, 695 indicating open water zone enlargement; in the second case the disappearance of the 696 thermokarst lakes and a change to terrestrial depositional conditions is suggested, as seen in the 697 uppermost parts of cores KB6 and KB7. Furthermore, the dominance of coarser rEMs as seen in the scores of the lower parts of these cores is interpreted to represent thermokarst initiation stages, characterized by in situ thaw and subsequent Yedoma deposit subsidence (for e.g. KB7 see also Ulrich et al., 2017b).

\subsection{Relationships between sedimentology and biogeochemistry in PCA}

703 The PCA ordination results show that the sedimentological characteristics of the rEMMA results are not or only very weakly correlated to the biogeochemical characteristics of the thermokarst deposits (Fig. 10). Statistical analysis suggests that biogeochemical parameters,

706 with the exception of MS and the Fe/Mn ratio, are independent of thermokarst deposit cryolithology and sedimentology. PC1 is dominated by all rEMs, the MS, and the Fe/Mn ratio, and can thus be considered to largely reflect grain-size variations and depositional conditions.

709 However, while the MS increases with the input of coarser-grained terrestrial source sediments 710 (rEM3 and rEM4), a higher Fe/Mn ratio and thus reducing lacustrine depositional conditions 
711 are related to the sedimentation of finer-grained sediments (rEM1 and rEM2) or less detritic

712 input. PC2 is dominated by the biogeochemical parameters with a general separation of organic-

713 indicating and inorganic-indicating parameters. PC2 can thus be considered to indicate post-

714 sedimentary biogeochemical conditions, lake level changes, and organic input.

715 After plotting the sample scores of PC1 and PC2 against each core depth (Figs. 6 and 7), we 716 can distinguish between fine-grained sedimentation along with rather high lake levels and/or 717 reducing conditions (higher PC1 and PC2 scores), and coarse-grained sedimentation with rather 718 shallow lake levels and/or oxidizing (i.e. terrestrial) conditions (lower PC1 and PC2 scores). 719 An exception is shown by the YU2 basin center core with always negative PC2 scores that are 720 likely the result of an exceptionally high $\mathrm{Fe} / \mathrm{S}$ ratio due to oxidizing conditions in the active 721 layer and unfrozen talik sediments after lake disappearance (Lenz et al., 2016).

723 5.4 Late Glacial to late Holocene environmental conditions and thermokarst basin evolution

724 The sedimentary and biogeochemical composition of thermokarst deposits are complex, but are 725 specifically marked by the alternation of terrestrial and lacustrine phases (Bouchard et al., 2017). 726 The paleoecological and paleolimnological conditions during thermokarst (lake) basin 727 formation are ideally reconstructed by the use of bioindicators such as chironomides (e.g., 728 Nazarova et al., 2013), diatoms (e.g., Pestryakova et al., 2012; Biskaborn et al., 2013a; 729 Bouchard et al., 2013), ostracodes (Wetterich et al., 2008; Ulrich et al., 2017b), pollen (e.g., 730 Katamura et al., 2006; Klemm et al., 2016), cladocera (Frolova et al., 2014, 2017), amoebae 731 (Lenz et al., 2016), and macro remain analyses (Schleusner et al., 2015). Therefore the 732 differentiation of sedimentary facies and palaeoenvironmental changes are usually based on a 733 multi-proxy approach and an adequate geochronology (Bouchard et al., 2017).

734 Deriving clear age-depth relationships for all the thermokarst sediment sequences from the KB 735 and YU study sites is challenging. Generally, care should be taken with the interpretation of 736 dating of thermokarst deposits due to repeated mixing of brought in Yedoma sediments as well 737 as changing bio-ecological conditions and the rearrangement of already deposited material 738 during thermokarst development (e.g., Biskaborn et al., 2013b; Lenz et al., 2016; Jongejans et 739 al., 2018). Having this in mind and due to the small-scale varying depositional environments 740 discussed above, our core locations cannot be compared by the sediment ages and it is not 741 possible to pinpoint a uniform stratigraphy over the studied sediment sequences (see also Fig. 7423,6 and 7). However, in particular the individual combination of macro remain and bulk ages 
743 as well as our multi-core and -proxy approach led us to discuss the Late Glacial to Holocene

744 evolution of thermokarst basins and geomorphological conditions in relation to literature-

745 derived environmental and climatic changes in CY during four time slices (Fig. 12). Following

746 Gaglioti et al. (2014) we assume that our macro remain ages (Tab.1) represent the true

747 sedimentation age of the sediment layer. This make sense because the sampled organic macro

748 remains originate from terrestrial plants (grasses, trees, etc.) that grew in the immediate vicinity

749 of an evolving thermokarst lake and were probably incorporated into thermokarst deposits

750 immediately after they died. Our bulk ages are interpreted as inherited ages of organic matter

751 from the Yedoma deposits, which subsequently subsided or were erosionally redeposited due

752 to thermokarst processes and lake growth (Biskaborn et al., 2013b; Gaglioti et al., 2014).

$754 \quad 5.4 .1$ Late Glacial - Early Holocene thermokarst initiation

755 It is generally assumed that thermokarst development in CY was initiated by the onset of the 756 Holocene (e.g., Katamura et al., 2006). According to Fradkina et al. (2005), thermokarst lakes 757 began to form near the end of the Late Glacial in the Allerød after about 13,300 cal. yrs. BP. 758 Katamura et al. (2009) suggest thermokarst initiation between 11,000 and 9000 cal. yrs. BP, 759 basing their assumption on increased charcoal and specific pollen findings in thermokarst 760 deposits. Biskaborn et al. (2012) discuss enhanced thermokarst processes in relation to a 761 transition to the mid-Holocene warm period after about 9100 cal. yrs. BP. Following former 762 research results in CY, lake sediment dating by Katasonov et al. (1979) for the KB study site 763 (Fig. 12a; see also above section 2), and in connection with the thermokarst sediment 764 rearrangement that is dated before the mid-Holocene Thermal Maximum (HTM) (see below 765 and Tab. 1), we assume that the onset of permafrost degradation at both study sites also took 766 place at the transition from Late Glacial to Early Holocene. Taking into account the 767 geomorphology of both studied basins, we assume, however, that the KB alas began to develop 768 earlier than the YU alas. Due to the climatic conditions during the Younger Dryas this likely 769 did not happen with the same intensity as later during the middle Holocene.

770 The late Pleistocene/Holocene transition in CY (ca. 11,.500 - 11,200 cal. yrs. BP) is 771 characterized by an abrupt increase in tree pollen and a decline in steppe vegetation (Andreev 772 et al., 1997; Fradkina et al., 2005; Andreev and Tarasov, 2013). During the Allerød Interstadial 773 the average temperatures first rose, then fell again during the Younger Dryas (YD; Andreev et 774 al., 2012). During the YD (between about 13,000 - 11,500 cal. yrs. BP), precipitation was about $775150 \mathrm{~mm}$ per year lower than today (Andreev et al., 1997; Andreev and Tarasov, 2013). A cold, 
dry phase during the YD was assumed as well by Biskaborn et al. (2012) for eastern Siberia; as they discussed, the resulting prolonged winter ice layer on thermokarst lakes caused reducing water conditions. Nazarova et al. (2013) show that colder conditions than today existed between 10,000 and 8000 cal. yrs. BP, but they assume wet summers also.

780

Although clear evidence of the thermokarst initiation timing could not be deduced from the studied sediments, we interpret the different biogeochemical characteristics of the lower basin center core parts $(>\mathrm{Fe} / \mathrm{Mn},>\mathrm{S},>\mathrm{CaCO} 3)$ as indicators for initial thermokarst processes (i.e. surface subsidence, ponding water; e.g. Bouchard et al., 2011; Biskaborn et al., 2013b; Schleusner et al., 2015; Figs. 6 and 7). The evolution of both studied thermokarst basins likely began at the KB3, YU2, and YU3 core locations (Fig. 12a). The late Pleistocene ages at the bottom of these sediment sequences does not show the "true" deposition age but rather indicate in situ thaw and subsequent Yedoma deposit subsidence (Tab. 1). The low TOC level in the KB3, YU2, and YU3 basin center cores also suggests further organic matter decomposition within a talik below the developing thermokarst lakes as described from taberal deposits found below Yedoma thermokarst lakes elsewhere (Schirrmeister et al., 2011a; Wetterich et al., 2012; Farquharson et al., 2016). The rEMs also show continuous low-energy deposition, a conclusion mainly supported by a strong influence of rEM1 and rEM2. However, the base of the thermokarst deposits was probably not drilled, as no grain size changes were found indicating the somewhat sandier facies typical for CY Yedoma deposits (Windirsch, 2018).

\subsubsection{Holocene thermal maximum thermokarst intensification}

Our results show high sedimentation rates and increased bioproductivity in the thermokarst deposits during the mid-HTM (about 7000 - 5000 cal. yrs. BP). This is especially evident by higher organic carbon contents and decreasing $\delta^{13} \mathrm{C}$ values in the KB7 core. In addition the YU1 profile, for example, shows increased TOC contents and strong sediment rearrangements during the middle Holocene. The exceptionally high KB7 core sedimentation rates in addition to lacustrine microfossil and palynological data analyses are interpreted by Ulrich et al. (2017b) to indicate rapid, highly dynamic lake evolution during the HTM. In particular, analysis of changes in the species composition of subfossil cladoceras communities made it possible to identify a rapid initiation, growth, and disappearance of an individual thermokarst lake at the KB7 location (Frolova et al., 2017; Ulrich et al., 2017b). Permafrost thaw and extensive thermokarst basin development was probably accelerated especially by rising precipitation (Monserud et al., 1998; Fradkina et al., 2005; Grosse et al., 2013; Nazarova et al., 2013). 
809 Terrestrial conditions changed quickly to lacustrine conditions, and thermokarst lakes rapidly 810 emerged and grew larger in a very short time before thermokarst processes declined locally 811 (Fig. 12b). The same can be seen in the KB6 sediment sequence of the small neighboring basin 812 at the KB study site. The grain-size means are higher in the lower and upper core parts but show 813 a significant increase of finer grain sizes (silt and clay) in the middle part. This change is also 814 reflected in the biogeochemical properties. However, the exact timing of lake drainage to the $815 \mathrm{~KB}$ basin is uncertain. The sedimentological and biogeochemical parameters from the upper core indicate changing phases of higher and lower lateral erosion and changing lake levels. A piece of wood sampled from about $90 \mathrm{~cm}$ bs was dated to $3316 \pm 61 \mathrm{cal}$. yrs. BP and originated 818 from a short, stable, but rather shallow lake phase (Fig. 3; Tab. 1). The basin center core locations were probably already in a distal position to the lake shore as indicated by homogeneous fine-grained sedimentation. However, the fluctuations in the $\mathrm{Fe} / \mathrm{Mn}$ and $\mathrm{Mg} / \mathrm{Ca}$ ratios indicate changing redox conditions during lake level changes.

The HTM is characterized by rising temperatures and higher precipitation in CY (Fradkina et al., 2005; Nazarova et al., 2013). According to Monserud et al. (1998), winter temperatures in Siberia were about $3.7^{\circ} \mathrm{C}$ and July means about $0.7^{\circ} \mathrm{C}$ warmer than today and annual rainfall was about $154 \mathrm{~mm}$ higher than today. Postglacial warming reached its maximum between about 6000 and 4600 cal. yrs. BP and was characterized by a similar vegetation composition as we see today in Siberia (Monserud et al., 1998). Biskaborn et al. (2012) suggest the warmest period of the mid-Holocene occurred between 7100 and 2800 cal. yrs. BP. At the HTM end, the unification of large thermokarst lake basins took place and alases appeared as they do today. The large pingos in the KB basin are an indication of that. Considering very slow pingo growth rates of a few millimeters per year (Soloviev, 1973), the existence of $\leqslant 12$-m-high pingos proves that permafrost aggradation and talik refreezing must have started at that time. Furthermore, the lenticular-layered to reticulate cryostructures as described from the basal parts of the sediment sequences (Fig. 4), in particular from the KB alas, indicate the vertical refreezing of subaqueous water-saturated talik deposits during lake disappearance (Katasonov and Ivanov, 1973; French and Shur, 2010).

837 Macro remain dating of the upper YU1 profile shows an age of $4606 \pm 175$ cal. yrs. BP and 838 indicates strong sediment rearrangement during the decaying HTM, likely by thermoerosional 839 processes at a lake basin shore. The uppermost sediments of the YU3 basin center core instead 840 reveal a macro remain date of $3975 \pm 102$ cal. yrs. BP and subaquatic to subaerial conditions at 841 that time. 


\subsubsection{Late Holocene thermokarst cessation}

844 Temperatures in eastern Siberia declined again after 4800 to 4500 cal. yrs. BP with minima 845 between 3000 and 2000 cal. yrs. BP (Biskaborn et al., 2012; Nazarova et al., 2013). This was 846 followed by a general warming trend and especially increasing winter temperatures in Siberia 847 but also more short-term temperature fluctuations (Meyer et al., 2015). Sedimentary conditions 848 are generally characterized by low carbon content, higher TOC/TN ratios, and low 849 sedimentation rates, all suggesting a general surface stability and permafrost aggradation below 850 large thermokarst basins during the late Holocene, However, very short favorable periods 851 probably led to higher lake levels and increasing thermoerosional processes at the basin edges. 852 In particular, the KB1 profile shows strong sediment rearrangements under subaquatic 853 conditions, likely via lake shore erosion and slumping processes between $1930 \pm 57$ and $8541812 \pm 72$ cal. yrs. BP. The higher sand content within the KB1 sediment sequence, the very 855 poor sorting of the grain sizes, and the multiple inversions of the radiocarbon dates indicate 856 high geomorphic dynamics at the basin edge. The rEM scores of the KB1 profile also show this 857 trend towards higher proportions of coarser grain sizes. The biogeochemical records like the 858 low TOC and $\mathrm{S}$ values as well as high, varying $\mathrm{TOC} / \mathrm{TN}, \mathrm{Mg} / \mathrm{Ca}$, and $\mathrm{Fe} / \mathrm{Mn}$ ratios suggest low 859 bioproductivity during sediment repositioning and accumulation and indicate increasing 860 subaerial conditions under short-term changing environmental conditions (Fig. 12c) (Biskaborn 861 et al., 2013b). Strong single events, e.g. collapsing lake-shore bluffs during lake expansion, are 862 an explanantion for the high sedimentation rates and comparable sedimentary conditions 863 (Biskaborn et al., 2013b; Lenz et al., 2013; Séjourné et al., 2015). However, we cannot directly 864 demonstrate comparable high geomorphologic dynamics in the YU thermokarst basin for the 865 same time period. Thus, a regional climate-relevant signal from late Holocene sediment 866 rearrangements as seen in the KB1 core cannot be detected. Our data point to the cessation of 867 thermokarst activity and extensive frost-induced processes (i.e. permafrost aggradation) for the 868 time after about 1.5 cal kyrs BP. Kachurin (1962) suggested that thermokarst processes in 869 Siberia were generally weaker during the late Holocene period. This is generally confirmed by 870 a late Holocene cooling trend, which is frequently observed from lake sediments in northeastern 871 Siberia (Popp et al., 2006; Swann et al., 2010; Biskaborn et al., 2012, 2013a; Klemm et al., 872 2016). 
876 Satellite images from the YU basin show different elevated ground levels of the alas bottom 877 around the YU3 and YU1 core locations, which are characterized by drier vegetation conditions 878 (Figs. 2 and 3; see also Ulrich et al., 2017a and their Fig. 2). Different basin ground levels likely 879 indicate small-scale differences in the ground-ice content of the underlying Yedoma deposits 880 and/or differing strong subsidence of the surface and lake deepening (e.g. Morgenstern et al., 881 2013). They probably also mark the former remnants of Yedoma uplands, which have separated several small thermokarst lakes basin before (Fig. 12b). However, the exact time of small lakes coalescing into a larger lake cannot be determined on the basis of the available data. Also, we believe that coalescence was more of a successive process, in which a lake with a higher water level drained into another when the Yedoma bridge between them was sufficiently thawed and eroded. The same is observed today at the YU study site, as the example of the YU5 location shows. This lake drained into the YU alas in spring 2007 after very rainy years (Ulrich et al., 2017a).

889 Contemporary northern latitude warming has been confirmed in numerous studies and it is 890 generally known that related environmental changes in the high, northern latitudes and 891 permafrost landscapes can occur very quickly (Serreze et al., 2000; Serreze and Barry, 2011; 892 Grosse et al., 2016; Walter-Anthony et al., 2018). After about 1500 cal. yrs. BP and a relatively 893 long period of relatively stabile, inactive thermokarst processes (Fig. 12d; e.g., Kachurin, 1962), 894 the gradual warming of permafrost over recent decades in Siberia has led to profound changes 895 in the ecosystem (Fedorov et al., 2014a; Iijima et al., 2016). In CY, the rise in temperature in addition to human impacts is leading to renewed high rates of subsidence and abrupt, rapid 897 thermokarst processes (Brouchkov et al., 2004; Fedorov and Konstantinov, 2009; Fedorov et 898 al., 2014b; Ulrich et al., 2017a). The thermokarst landscape in CY is characterized by a long 899 history of human land use (settlements, agriculture, horse and cattle breeding) since the 900 settling/colonization by the Yakut (Sakha) during the 13th century; these activities occurred on 901 the alases, influenced by thaw lake dynamics (Crate et al., 2017). Above all, the YU5 sediment sequence from the neighboring small basin at the YU study site documents very well this subrecent time period. During the short life of the thermokarst lake which developed in a former agricultural area, strong surface subsidence and lateral lake basin expansion took place (Ulrich et al., 2017a). However, we identified very little accumulation of lacustrine sediments . Thus, we expect very low sedimentation rates in modern rapidly growing thermokarst lakes. Finally, this shows that rapid thermokarst processes can happen during even short-term warm climate 
conditions. This is proved for the past, is still comprehensible today in many permafrost areas and, above all, is accelerated by human land use in CY.

\section{Conclusion}

912 Our study emphasizes that alas and thermokarst lake evolution in CY Yedoma landscapes were 913 not a continuous process during the Late Glacial to Holocene period. Short-term phases of 914 forcing climatic conditions have led to very active thermokarst processes and rapid but locally 915 variable landscape modification. Similar processes are observed in the study region under 916 current climatic changes.

917 Specific sedimentological and biogeochemical thermokarst deposit characteristics allow the 918 reconstruction of erosion, transport, and sedimentation conditions. In particular, the GSD 919 unmixing procedure of the rEMMA offered us a unique and robust method to detect specific 920 grain-size fractionation and depositional processes during thermokarst development. This is not 921 possible by simple ordination methods (e.g., PCA) that usually cannot handle multimodal data 922 and require data linearity or by manual evaluation of the polymodal GSDs from the rearranged 923 polygenetic Yedoma source sediments. The biogeochemical parameters are statistically 924 separated into organic-dominated (e.g., TOC, TOC/TN, S, Mg/Ca) and inorganic-dominated 925 processes (e.g., $\mathrm{CaCO}_{3}, \mathrm{Fe} / \mathrm{S}, \delta 13 \mathrm{C}$ ). However, their general weak correlation to the 926 sedimentological characteristics represented by the four final rEMs are suggesting post927 sedimentary biogeochemical conditions, lake level changes, and varying organic input.

928 Considering the rather low time resolution of our study as well as the discussed difficulties in dating of thermokarst sediments and the small-scale sedimentation differences, the results of 930 the radiocarbon dating confirm an extensive deposition of reworked late Pleistocene Yedoma source sediments in peripheral basin zones during thermokarst lake growth. The basin centers

932 are characterized by in situ thaw and subsidence of late Pleistocene sediments during early 933 thermokarst evolution phases, but the subsequent accumulation of clayey and fine silt sediments 934 is assigned to a distal transport or a low-energy sedimentation milieu under increasing lacustrine 935 conditions. Finally, the synopsis of rEMMA and all analyzed proxies in relation to the geomorphological location of the cores reveals small-scale variability of sediment origin in each CY alas. Individual small-scale varying depositional environments of many rapidly growing small thermokarst lakes and basins during the mid-HTM, which finally coalesced, have formed the large thermokarst basins we see today in CY. 


\section{Authors contribution}

941 MU conceptualized the project, acquired the funding, collected the profiles, analyzed the data, 942 and wrote the manuscript. HM did the rEMMA, the statistical analysis, and wrote parts of and 943 corrected the manuscript. JoS, CS, LS, and AF assisted during field work, organized field work 944 logistics, did laboratory and data analysis, and/or wrote and corrected parts of the paper. BS did 945 the XRF laboratory analysis and corrected the paper. JeS and CZ have been involved in the 946 study and project design and advanced the manuscript with their ideas.

\section{Data availability}

948 All data for this paper are properly cited and referenced in the reference list. Moreover, data 949 may be available upon request to the corresponding author, or are already available as 950 supplementary data.

\section{Conflict of interest}

952 The authors declare that they have no conflict of interest.

\section{Acknowledgements}

954 We greatly appreciate the efforts of all Russian and German colleagues in organizing and 955 supporting the field work and lab analyses. We thank in particular Alexey R. Desyatkin, 956 Avksenty Kondakov, and Peter V. Efremov for field and drilling assistance and Katja Pöhlmann 957 for laboratory assistance. The paper benefited by English proof-reading and valuable comments 958 from Candace S. O’Connor (Scientific Editor, Fairbanks, Alaska). We are very thankful for 959 valuable comments and constructive reviews by two anonymous referees.

\section{$960 \quad$ Funding}

961 MU was supported by the German Research Foundation (DFG Grant No.: UL426/1-1) and the 962 Japan Society for the Promotion of Science (FY2018 JSPS Invitational Fellowship for Research 963 in Japan (Long-term), ID-No. L18558). AF was supported by the Russian Federal for Basic 964 Research (ID-No. 18-45-140046). JeS was supported by the European Research Council 965 (Starting Grant \#338335) and the Initiative and Networking Fund of the Helmholtz Association 966 (\#ERC-0013). LS and JeS aknowledge the German Federal Ministry of Education and Research 967 (“CarboPerm” (03G0836A) and "KoPF” (03F0764A)). 


\section{References}

970 Andreev, A.A., Klimanov, V.A., Sulerzhitsky, L.D., 1997. Younger Dryas pollen records from 971 central and southern Yakutia. Quat. Int. 41-42, 111-117.

972 Andreev, A.A., Schirrmeister, L., Tarasov, P.E., Ganopolski, V., Brovkin, V., Siegert, C., 973 Wetterich, S., Hubberten, H.-W., 2012. Vegetation and climate history in the Laptev Sea region 974 (Arctic Siberia) during Late Quaternary inferred from pollen records. Quat.- Sci. Rev. 30, 21829752199.

976 Andreev, A.A, Tarasov, P.E., 2013. Northern Asia. In: Elias, S.A. (ed.) The Encyclopedia of 977 Quaternary Science, vol. 4, Amsterdam: Elsevier, pp. 164-172.

978 Biskaborn, B.K., Herzschuh, U., Bolshiyanov, D., Savelieva, L., Diekmann, B., 2012. 979 Environmental variability in northeastern Siberia during the last $\sim 13,300 \mathrm{yr}$ inferred from lake 980 diatoms and sediment-geochemical parameters. Palaeogeogr. Palaeoecol. 329-330, 22-36. 981 https://doi.org/10.1016/j.palaeo.2012.02.003.

982 Biskaborn, B.K., Herzschuh, U., Bolshiyanov, D., Savelieva, L., Zibulski, R., Diekmann, B., 983 2013a. Late Holocene thermokarst variability inferred from diatoms in a lake sediment record 984 from the Lena Delta, Siberian Arctic. J. Paleolimnol. 49, 155-170.

985 Biskaborn, B.K., Herzschuh, U., Bolshiyanov, D.Y., Schwamborn, G., Diekmann, B., $2013 b$. 986 Thermokarst processes and depositional events in a tundra lake, northeastern Siberia. 987 Permafrost Periglacial Processes 24(3), 160-174.

988 Biskaborn, B.K, Subetto, D.A., Savelieva, L.A., Vakhrameeva, P.S., Hansche, A., Herschuh, 989 U., Klemm, J., Heinecke, L., Pestryakova, L.A., Meyer, H., Kuhn, G., 2016. Late Quaternary 990 vegetation and lake system dynamics in north-eastern Siberia: Implications for seasonal climate 991 variability. Quat. Sci. Rev. 147, 406-421.

992 Blott, S.J., Pye, K., 2001. GRADISTAT: a grain size distribution and statistics package for the 993 analysis of unconsolidated sediments. Earth Surf. Proc. Land. 26(11), 1237-1248.

994 Bosikov, N.P., 1998. Wetness variability and dynamics of thermokarst processes in Central 995 Yakutia, in: Proceedings of the 7th International Permafrost Conference, June 23-27, 1998, 996 Yellowknife, Canada, Nordicana 57, 71-74. 
Bouchard, F., Francus, P., Pienitz, R., Laurion, I., 2011. Sedimentology and geochemistry of thermokarst ponds in discontinuous permafrost, subarctic Quebec, Canada. J. Geophys. Res., 116. G00M04. doi: 10.1029/2011JG001675.

1000

1001

1002

1003

1004

1005

1006

1007

1008

1009

1010

1011

1012

1013

1014

1015

1016

1017

1018

1019

1020

1021

1022

1023

1024

1025

1026

Bouchard, F., Pienitz, R., Ortiz, J.D., Francus, P., Laurion, I., 2013. Palaeolimnological conditions inferred from fossil diatom assemblages and derivative spectral properties of sediments in thermokarst ponds of subarctic Quebec, Canada. Boreas 42(3), 575-595.

Bouchard, F., Francus, P., Pienitz, R., Laurion, I., Feyte, S., 2014. Subarctic thermokarst ponds: Investigating recent landscape evolution and sediment dynamics in thawed permafrost of northern Québec (Canada). Arct. Antarct. Alp. Res. 46(1), 251-271.

Bouchard, F., MacDonald, L.A., Turner, K.W., Thienpont, J.R., Medeiros, A.S., Biskaborn, B.K., Korosi, J., Hall, R.I., Pienitz, R., Wolfe, B.B., 2017. Paleolimnology of thermokarst lakes: a window into permafrost landscape evolution. Arct. Sci. 3, 91-117.

Brouchkov, A., Fukuda, M., Fedorov, A., Konstantinov, P., Iwahana, G., 2004. Thermokarst as a short-term permafrost disturbance, Central Yakutia. Permafrost Periglac. 15, 81-87.

Brown J., Ferrians, Jr. O.J., Heginbottom, J.A., Melnikov, E.S., 2002. Circum-Arctic Map of Permafrost and Ground-Ice Conditions, Version 2. National Snow and Ice Data Center, Boulder: Colorado, USA.

Crate, S., Ulrich, M., Habeck, J.O., Desyatkin, A.R., Desyatkin, R.V., Fedorov, A.N., Hiyama, T., Iijima, Y., Ksenofontov, S., Mészáros, C., Takakura, H., 2017. Permafrost livelihoods: A transdisciplinary review and analysis of thermokarst-based systems of indigenous land use. Anthropocene 18, 89-104.

Czudek, T., Demek, J., 1970. Thermokarst in Siberia and its influence on the development of lowland relief. Quat. Res. 1, 103-120.

Davison, W., 1993. Iron and manganese in lakes. Earth-Sci. Rev. 34(2), 119-163.

Desyatkin, R.V., 2008. Soil formation in thermokarst depressions - Alases of cryolithozone, Novosibirsk "Nauka”. (in Russian)

Dietze, E., Hartmann, K., Diekmann, B., IJmker, J., Lehmkuhl, F., Opitz, S., Stauch, G., Wünnemann, B., Borchers, A., 2012. An end-member algorithm for deciphering modern detrital processes from lake sediments of Lake Donggi Cona, NE Tibetan Plateau, China. Sediment. Geol. 243-244, 169-180. 
1027 Dietze, E., Maussion, F., Ahlborn, M., Diekmann, B., Hartmann, K., Henkel, K., Kasper, T., 1028 Lockot, G., Opitz, S., Haberzettl, T., 2014. Sediment transport processes across the Tibetan 1029 Plateau inferred from robust grain-size end members in lake sediments. Clim. Past 10(1), 911030106.

1031 Dietze, E, Dietze, M., 2019. Grain-size distribution unmixing using the R package EMMAgeo. 1032 E\&G Quarternary Sci. J., 68, 29-46.

1033 Dietze, M., Dietze, E., Lomax, J., Fuchs, M., Kleber, A., Wells, S., 2016. Environmental history 1034 recorded in aeolian deposits under stone pavements, Mojave Desert, USA. Quaternary Research, 1035 85(1), 4-16. doi:10.1016/j.yqres.2015.11.007.

1036 Evans, M.E., Heller, F., Bloemendal, J., Thouveny, N., 1997. Natural magnetic archives of past 1037 global change. Surv. Geophys. 18, 183-196.

1038 Farquharson, L., Walter Anthony, K., Bigelow, N., Edwards, M., Grosse, G., 2016. Facies 1039 analysis of yedoma thermokarst lakes on the northern Seward Peninsula, Alaska. Sediment. 1040 Geol. 340, 25-37.

1041 Fedorov, A.N., Konstantinov, P.Y., 2003. Observation of surface dynamics with thermokarst 1042 initiation, Yukechi site, CY, in: Permafrost: Proceedings of the 8th International Conference on 1043 Permafrost, 21-25 July 2003, pp. 239-243, Zürich, Switzerland.

1044 Fedorov, A.N., Konstantinov, P.Y., 2008. Recent changes in ground temperature and the effect 1045 on permafrost landscapes in CY, in: Kane, D.L., Hinkel, K.M. (Eds.), Proceedings of the Ninth 1046 International Conference on Permafrost, University of Alaska Fairbanks, June 29-July 3, 2008, 1047 Institute of Northern Engineering, University of Alaska, Fairbanks, pp. 433-438.

1048 Fedorov, A.N., Konstantinov P.Y., 2009. Response of permafrost landscapes of Central Yakutia 1049 to current changes of climate, and anthropogenic impacts. Geograph. Nat. Resour., 30, 146-150.

1050 Fedorov, A.N., Ivanova, R.N., Park, H., Hiyama, T., Iijima, Y., 2014a. Recent air temperature 1051 changes in the permafrost landscapes on northeastern Eurasia. Polar Sci. 8(2), 114-128.

1052 Fedorov, A.N., Gavriliev, P.P., Konstantinov, P.Y., Hiyama, T., Iijima, Y., Iwahana, G., $2014 b$. 1053 Estimating the water balance of a thermokarst lake in the middle of the Lena River basin, eastern 1054 Siberia. Ecohydrology 7(2), 188-196. 
1055 Flemming, B.W., 2007. The influence of grain-size analysis methods and sediment mixing on curve shapes and textural parameters: Implications for sediment trend analysis. Sediment. Geol. 202(3), 425-435.

1058 Folk, R.L., Ward, W.C., 1957. Brazos River Bar: A study in the significance of grain size 1059 parameters. J. Sediment. Petrol. 27(1), 3-26.

1060 Fradkina, A.F., Alekseev, M.N., Andreev, A.A., Klimanov, V.A., 2005. East Siberia. In: 1061 Velichko, A.A., Nechaev, V.P. (Eds). Cenozoic Climatic and Environmental Changes in Russia, 1062 London, The Geological Society of America (Special Paper 382), pp. 105-120.

1063 French, F., Shur, Y., 2010. The principles in cryostratigraphy. Earth-Sci. Rev. 101, 190-206.

1064 Fritz, M. . Unkel, I., Lenz, J., Gajewski, K, Frenzel, P., Paquette, N., Lantuit, L., Körte, L., 1065 Wetterich, S., 2018. Regional environmental change versus local signal preservation in 1066 Holocene thermokarst lake sediments: A case study from Herschel Island, Yukon (Canada). J 1067 Paleolimnol (2018) 60:77-96. doi.org/10.1007/s10933-018-0025-0

1068 Frolova, L.A., Nazarova, L., Pestryakova, L.A., Herzschuh, U., 2014. Subfossil cladoceran 1069 remains from sediment in thermokarst lakes in northeastern Siberia, Russia in relation to 1070 limnological and climatic variables. J. Paleolim. 52, 107-119.

1071 Frolova, L.A., Ibragimova, A.G., Ulrich, M., Wetterich, S., 2017. Reconstruction of the history 1072 of a thermokarst lake in the Mid-Holocene based on an analysis of subfossil cladocera (Siberia, 1073 Central Yakutia). Cont. Probl. Ecol. 10(4), 423-430.

1074 Gaglioti, B.V., Mann, D.H., Jones, B.M., Pohlman, J.W., Kunz, M.L., Wooller, M.J., 2014. 1075 Radiocarbon age-offsets in an arctic lake reveal the long-term response of permafrost carbon to 1076 climate change. J. Geophys. Res.-Biogeo. 119(8), 1630-1651.

1077 Gavrilova, M.K., 1973. Climate of Central Yakutia. Akademiya Nauk, Institut 1078 Merzlotovedeniya, Yakutsk, SSSR, pp 120. (in Russian)

1079 Global Wind Atlas (2018). A free, web-based application developed, owned and operated by 1080 the Technical University of Denmark (DTU) in partnership with the World Bank Group, 1081 utilizing data provided by Vortex, with funding provided by the Energy Sector Management 1082 Assistance Program (ESMAP). https://globalwindatlas.info/ (accessed 9 April 2019).

1083 Grosse, G., Jones, J., Arp, C., 2013. Thermokarst lakes, drainage, and drained basins, in: 1084 Shroder, J.F. (Ed.), Treatise on Geomorphology, San Diego, Academic Press, pp. 325-353. 
1085 Grosse, G., Goetz, S., McGuire, A.D., Romanovsky, V.E., Schuur, E.A.G., 2016. Changing permafrost in a warming world and feedbacks to the Earth system. Environ. Res. Lett. 11, 040201, doi:10.1088/1748-9326/11/4/040201.

1088 Haberzettl, T., Corbella, H., Fey, M., Janssen, S., Lücke, A., Mayr, C., Ohlendorf, C., Schäbitz, 1089 F., Schleser, G.H., Wille, M., Wulf, S., Zolitschka, B., 2007. Lateglacial and Holocene wet1090 dry cycles in southern Patagonia: chronology, sedimentology and geochemistry of a lacustrine 1091 record from Laguna Potrok Aike, Argentina. Holocene 17, 297-310.

1092 Hamann, Y., Ehrmann, W., Schmiedl, G., Krüger, S., Stuut, J.-B., Kuhnt, T., 2008. 1093 Sedimentation processes in the Eastern Mediterranean Sea during the Late Glacial and 1094 Holocene revealed by endmember modelling of the terrigenous fraction in marine sediments. 1095 Mar. Geol. 248(1-2), 97-114.

1096 Hanesch, M., Scholger, R., 2005. The influence of soil type on the magnetic susceptibility 1097 measured throughout soil profiles. Geophys. J. Int. 161(1), 50-56.

1098 Hartmann, D., 2007. From reality to model: Operationalism and the value chain of particle-size 1099 analysis of natural sediments. Sediment. Geol. 202(3), 383-401.

1100 Iijima, Y., Ohta, T., Kotani, A., Fedorov, A.N., Kodama, Y., Maximov, T.C., 2014. Sap flow 1101 changes in relation to permafrost degradation under increasing precipitation in an eastern 1102 Siberian larch forest. Ecohydrology 7, 177-187.

1103 Iijima, Y., Nakamura, T., Hotaek, P., Tachibana, Y., Fedorov, A.N., 2016. Enhancement of 1104 Arctic storm activity in relation to permafrost degradation in eastern Siberia. Int. J. Clim., 36, $1105 \quad 4265-4275$.

1106 Ijmker, J., Stauch, G., Dietze, E., Hartmann, K., Diekmann, B., Lockot, G., Opitz, S., 1107 Wünnemann, B., Lehmkuhl, F., 2012. Characterisation of transport processes and sedimentary 1108 deposits by statistical end-member mixing analysis of terrestrial sediments in the Donggi Cona 1109 lake catchment, NE Tibetan Plateau. Sediment. Geol. 281, 166-179.

1110 IPCC (Intergovernmental Panel on Climate Change) 2013, in: Stocker, T.F., Qin, D., Plattner, 1111 G.-K., Tignor, M., Allen, S.K., Boschung, J., Nauels, A., Xia, J., Bex, V., Midgley, P.M. (eds), 1112 Climate Change 2013: The Physical Science Basis, Contribution Working Group I to the Fifth 1113 Assessment Report of the Intergovernmental Panel on Climate Change, Cambridge, Cambridge 1114 Univ. Press., pp. 3-29. 
1115 Ji, S., Xingqi, L., Sumin, W., Matsumoto, R., 2005. Palaeoclimate changes in the Qinghai Lake 1116 area during the last 18,000 years. Quat. Int. 136, 131-140.

1117 Jongejans, L.L., Strauss, J., Lenz, J., Peterse, F., Mangelsdorf, K., Fuchs, M, Grosse, G., 2018. 1118 Organic matter characteristics in yedoma and thermokarst deposits on Baldwin Peninsula, west 1119 Alaska. Biogeosciences, 15 (2), 6033 - 6048.

1120 Josse, J., Husson, F., 2016. missMDA: A package for handling missing values in multivariate 1121 data analysis. Journal of Statistical Software, 70(1), 1-31. doi: 10.18637/jss.v070.i01.

1122 Kachurin, S.P., 1962. Thermokarst within the territory of the USSR. Biuletyn Peryglacjalny, 1123 11, 49-55. (In Russian.)

1124 Katamura, F., Fukuda, M., Bosikov, N.P., Desyatkin, R.V., Nakamura, T., Moriizumi, J., 2006. 1125 Thermokarst formation and vegetation dynamics inferred from a palynological study in Central 1126 Yakutia, Eastern Siberia, Russia. Arct. Antarct. Alp. 38, 561-570.

1127 Katamura, F., Fukuda, M., Bosikov, N.P., Desyatkin, R.V., 2009. Charcoal records from 1128 thermokarst deposits in central Yakutia, eastern Siberia: Implications for forest fire history and 1129 thermokarst development. Quat. Res. 71(1), 36-40.

1130 Katasonov, E.M., Ivanov, M.S., 1973. Cryolithology of Central Yakutia: Guidebook, II 1131 International Conference on Permafrost, Yakutsk. USSR Academy of Sciences, Siberian 1132 Division, Yakutsk, 38 pp.

1133 Katasonov, E.M., Ivanov, M.S., Pudov, G.G., Siegert, C., Katasonova, E.G., 1979. Structure 1134 and absolute geochronology of alas deposits in Central Yakutia. Moscow, Nauka. (in Russian).

1135 Klemm, J., Herschuh, U., Pestryakova, L.A., 2016. Vegetation, climate and lake changes over 1136 the last 7000 years at the boreal treeline in north-central Siberia. Quat. Sci. Rev. 147, 422-434.

1137 Klovan, J.E., Imbrie, J., 1971. An algorithm and Fortran-IV program for large-scale Q-mode 1138 factor analysis and calculation of factor scores. Math. Geol. 3(1), 61-77.

1139 Lenz, J., Fritz, M., Wetterich, S., Schirrmeister, L., Lantuit, H., Wooller, M.J., Pollar, W.H., 1140 Wetterich, S., 2013. Periglacial landscape dynamics in the West-Canadian Arctic - Results 1141 from a lake record on a push moraine (Herschel Island, Yukon Territory). Palaeogeogr. 1142 Palaeoecol. 381-382, 15-25.

1143 Lenz, J., Grosse, G., Jones, B.M., Walter Anthony, K.M., Bobrov, A., Wulf, S., Wetterich, S., 1144 2016. Mid-Wisconsin to Holocene permafrost and landscape dynamics based on a drained lake 
1145 basin core from the northern Seward Peninsula, Northwest Alaska. Permafr. Periglac. 27(1), $114656-75$.

1147 Liu, X., Herschuh, U., Shen, J., Jiang, Q., Xiao, X., 2008. Holocene environmental and climatic 1148 changes inferred from Wulungu Lake in northern Xinjiang, China. Quat. Res. 70, 412-425.

1149 Macumber, A.L., Patterson, R.T., Galloway, J.M., Falck, H., Swindles, G.T., 2018. 1150 Reconstruction of Holocene hydroclimatic variability in subarctic treeline lakes using lake 1151 sediment grain-size end-members. The Holocene 28(6), 845-857.

1152 Matasova, G., Petrovský, E., Jordanova, N., Zykina, V., Kapička, A., 2001. Magnetic study of 1153 Late Pleistocene loess/palaeosol sections from Siberia: palaeoenvironmental implications. 1154 Geophys. J. Int. 147(2), 367-380.

1155 Melillo, J.M., Aber, J.D., Linkins, A.E., Ricca, A., Fry, B., Nadelhozer, K. J., 1989. Carbon 1156 and nitrogen dynamics along the decay continuum: Plant litter to soil organic matter. Plant and 1157 Soil, 115, 189-198.

1158 Meyer, H., Opel, T., Laepple, T., Dereviagin, A. Y., Hoffmann, K., Werner, M., 2015. Long1159 term winter warming trend in the Siberian Arctic during the mid- to late Holocene, Nature 1160 Geosci., 8, 122-125.

1161 Meyers, P.A., 1994. Preservation of elemental and isotopic source identification of sedimentary 1162 organic matter. Chem. Geol. 114(3-4), 289-302.

1163 Meyers, P.A., Lallier-Vergès, E., 1999. Lacustrine sedimentary organic matter records of Late 1164 Quaternary paleoclimates. J. Paleolim. 21, 345-372.

1165 Meyers, P.A., Teranes, J.L., 2001. Sediment organic matter, in: Last, W.M., Smol, J.P. (Eds.), 1166 Tracking Environmental Changes Using Lake Sediments_-Volume II: Physical and Chemical 1167 Techniques. Kluwer, Dordrecht, pp. 239-269.

1168 Mirkin, B.M., Gogoleva, P.A., Kononov, K.E., 1985. The vegetation of Central Yakutian alases. 1169 Folia Geobot. Phytotax. 20, 345-395.

1170 Monserud, R.A., Tchebakova, N.M., Denissenko, O.V., 1998. Reconstruction of the mid1171 Holocene palaeoclimate of Siberia using a bioclimatic vegetation model. Palaeogeogr. 1172 Palaeoecol. 139, 15-36. 
1173 Morgenstern, A., Grosse, G., Günther, F., Fedorova, I., Schirrmeister, L., 2011. Spatial analyses 1174 of thermokarst lakes and basins in Yedoma landscapes of the Lena Delta. The Cryosphere 5, $1175849-867$.

1176 Morgenstern, A., Ulrich, M., Günther, F., Roessler, S., Fedorova, I.V., Rudaya, N.A., Wetterich, 1177 S., Boike, J., Schirrmeister, L., 2013. Evolution of thermokarst in East Siberian ice-rich 1178 permafrost - a case study. Geomorphology 201, 363-379.

1179 Nazarova, L., Lüpfert, H., Subetto, D., Pestryakova, L.A., Diekmann, B., 2013. Holocene 1180 climate conditions in central Yakutia (Eastern Siberia) inferred from sediment composition and 1181 fossil chironomids of Lake Temje. Quat. Int. 290-291, 264-274.

1182 Nottebaum, V., Stauch, G., Hartmann, K., Zhang, J., Lehmkuhl, F., 2015. Unmixed loess grain 1183 size populations along the northern Qilian Shan (China): Relationships between 1184 geomorphologic, sedimentologic and climatic controls. Quat. Int. 372, 151-166.

1185 O‘Leary, M.H., 1981. Carbon isotope fractionation in plants. Phytochemistry 20(4), 553- 567.

1186 Olefeldt, D., Goswami, S., Grosse, G., Hayes, D., Hugelius, G., Kuhry, P., McGuire, A. D., 1187 Romanovsky, V.E., Sannel, A.B.K., Schuur, E.A.G., Turetsky, M.R., 2016. Circumpolar 1188 distribution and carbon storage of thermokarst landscapes. Nat. Commun.7, 13043, 1189 doi:10.1038/ncomms13043 (2016)

1190 Opitz, S., Ramisch, A., Mischke, S., Diekmann, B., 2013. Holocene lake stages and thermokarst 1191 dynamics in a discontinuous permafrost affected region, north-eastern Tibetan Plateau. J. Asian 1192 Earth Sci. 76, 85-94.

1193 Pestryakova, L.A., Herzschuh, U., Wetterich, S., Ulrich, M., 2012. Present-day variability and 1194 Holocene dynamics of permafrost-affected lakes in central Yakutia (Eastern Siberia) inferred 1195 from diatom records. Quat. Sci. Rev. 51, 56-70.

1196 Popp, S., Diekmann, B., Meyer, H., Siegert, C., Syromyatnikov, I., Hubberten, H.-W., 2006. 1197 Palaeoclimate signals as inferred from stable-isotope composition of ground ice in the 1198 Verkhoyansk Foreland, Central Yakutia. Permafrost Periglacial Processes 17, 119-132.

1199 Péwé, T.L., Journaux, A., 1983. Origin and character of loess-like silt in unglaciated south1200 central Yakutia, Siberia, USSR. US Geological Survey Professional Paper 1262.

1201 R Core Team, 2014. R. A language and environment for statistical computing. Version 3.1.1. 1202 Wien: R Foundation for Statistical Computing. Online available: http://www.R-project. org/. 
1203 Reimer, P., Bard, E., Bayliss, A., Beck, J., Blackwell, P., Ramsey, C., Buck, C.E., Cheng, H., 1204 Edwards, R.L., Friedrich, M., Grootes, P.M., Guilderson, T.P., Haflidason, H., Hajdas, I., Hatté, 1205 C., Heaton, T.J., Hoffmann, D.L., Hogg, A.G., Hughen, K.A., Kaiser, K.F., Kromer, B., 1206 Manning, S.W., Niu, M., Reimer, R.W., Richards, D.A., Scott, E.M., Southon, J.R., Staff, R.A., 1207 Turney, C.S.M., Van der Plicht, J., 2013. IntCal13 and Marine13 Radiocarbon Age Calibration 1208 Curves 0-50,000 Years cal BP. Radiocarbon 55(4), 1869-1887.

1209 Santoro, M., Strozzi, T., 2012. Circumpolar digital elevation models $>55^{\circ} \mathrm{N}$ with links to 1210 geotiff images. doi:10.1594/PANGAEA.779748.

1211 Schirrmeister, L., Kunitsky, V., Grosse, G., Wetterich, S., Meyer, H., Schwamborn, G., Babiy, 1212 O., Derevyagin, A., Siegert, C., 2011a. Sedimentary characteristics and origin of the Late 1213 Pleistocene Ice Complex on north-east Siberian Arctic coastal lowlands and islands - A review. 1214 Quat. Int. 241(1-2), 3-25. http://doi:10.1016/j.quaint.2010.04.004.

1215 Schirrmeister, L., Grosse, G., Schnelle, M., Fuchs, M., Krbetschek, M., Ulrich, M., Kunitsky, 1216 V., Grigoriev, M., Andreev, A., Kienast, F., Meyer, H., Babiy, O., Klimova, I., Bobrov, A., 1217 Wetterrich, S., Schwamborn, G., 2011b. Late Quaternary paleoenvironmental records from the 1218 western Lena Delta, Arctic Siberia. Palaeogeogr. Palaeoecol. 299(1-2), 175-196. doi: $1219 \quad 10.1016 / \mathrm{j} . q u a s c i r e v .2009 .11 .017$.

1220 Schirrmeister, L., Grosse, G., Wetterich, S., Overduin, P.P., Strauss, J., Schuur, E.A.G., 1221 Hubberten, H.-W., 2011c. Fossil organic matter characteristics in permafrost deposits of the 1222 northeast Siberian Arctic. J. Geophys. Res. 116. DOI: 10.1029/2011JG001647.

1223 Schirrmeister, L., Froese, D., Tumskoy, V., Grosse, G., Wetterich, S., 2013. Yedoma: Late 1224 Pleistocene ice-rich syngenetic permafrost of Beringia, in: Elias S.A. (ed.), The Encyclopedia 1225 of Quaternary Science 2nd edition, vol. 3, Amsterdam, Elsevier, pp. 542-552.

1226 Schirrmeister, L., Schwamborn, G., Overduin, P.P., Strauss, J., Fuchs, M.C., Grigoriev, M., 1227 Yakshina, I., Rethemeyer, J., Dietze, E., Wetterich, S., 2017. Yedoma ice complex of the Buor 1228 Khaya Peninsula (southern Laptev Sea). Biogeosciences 14, 1261-1283. doi:10.5194/bg-14$1229 \quad 1261-2017$

1230 Schleusner, P., Biskaborn, B.K., Kienast, F., Wolter, J., Subetto, D., Diekmann, B., 2015. Basin 1231 evolution and palaeoenvironmental variability of the thermokarst lake El'gene-Kyuele, Arctic 1232 Siberia. Boreas 44, 216-229. 
1233 Séjourné, A., Costard, F., Fedorov, A.N., Gargani, J., Skorve, J., Massé, M., Mège, D., 2015.

1234 Evolution of the banks of thermokarst lakes in Central Yakutia (Central Siberia) due to 1235 retrogressive thaw slump activity controlled by insolation. Geomorphology 241, 31-40.

1236 Serreze, M.C., Walsh, J.E., Chapin III, F.S., Osterkamp, T., Dyugerov, M., Romanovsky, V.E., 1237 Oechel, W.C., Morison, J., Zhang, T., Barry, R.G., 2000. Observational evidence of recent 1238 change in the northern high-latitude environment. Clim. Change 46, 159-207.

1239 Serreze, M.C., Barry, R.G., 2011. Processes and impacts of Arctic amplification: A research 1240 synthesis. Glob. Planet. Change 77, 85-96.

1241 Siegert, C., 1979. Minerologic-petrographic characteristic of alas deposits. in: Katasonov, E.M. 1242 (Ed.), Structure and absolute geochronology of alas deposits in Central Yakutia, Moscow, 1243 Nauka, pp. 44-61. (In Russian).

1244 Siegert, C., 1987. Greigite and Mackinawite in Quaternary deposits of Central Yakutia. 1245 Mineralogicheskiy Zhurnal 9(5), 75-81. (In Russian).

1246 Soloviev, P.A., 1959. Cryolithic zone of the northern part of Lena-Amga interfluve. Moscow, 1247 Izdatel'stvo Akademii SSSR, pp. 142. (in Russian).

1248 Soloviev, P.A., 1973. Thermokarst phenomena and landforms due to frost heaving in Central 1249 Yakutia. Biuletyn Peryglacjalny 23, 135-155.

1250 Stendel, M., Christensen, J.H., 2002. Impact of global warming on permafrost conditions in a 1251 coupled GCM. Geophys. Res. Lett. 29(13), DOI: 10.1029/2001GL014345.

1252 Strauss, J., Schirrmeister, L., Wetterich, S., Borchers, A, Davydov S.P., 2012. Grain-size 1253 properties and organic-carbon stock of Yedoma Ice Complex permafrost from the Kolyma 1254 lowland, northeastern Siberia. Global Biogeochem. Cy. 26, GB3003. 1255 doi:10.1029/2011GB004104.

1256 Strauss, J., Schirrmeister, L., Grosse, G., Wetterich, S., Ulrich, M., Herzschuh, U., Hubberten, 1257 H.-W., 2013. The deep permafrost carbon pool of the Yedoma region in Siberia and Alaska. 1258 Geophys. Res. Lett. 40, 6165-6170. doi:10.1002/2013GL058088.

1259 Strauss, J., Schirrmeister, L., Mangelsdorf, K., Eichhorn, L., Wetterich, S., Herzschuh, U., 2015. 1260 Organic-matter quality of deep permafrost carbon - a study from Arctic Siberia. Biogeosciences, 1261 12(7), 2227-2245. doi:10.5194/bg-12-2227-2015. 
1262 Strauss, J., Schirrmeister, L., Grosse, G., Fortier, D., Hugelius, G., Knoblauch, C., Romanovsky, 1263 V., Schädel, C., Schneider von Deimling, T., Schuur, E.A.G., Shmelev, D., Ulrich, M., 1264 Veremeeva, A., 2017. Deep Yedoma permafrost: A synthesis of depositional characteristics 1265 and carbon vulnerability. Earth-Sci. Rev. 172, 75-86. doi: 10.1016/j.earscirev.2017.07.007.

1266 Stuiver, M., Polach, H.A., 1977. Discussion: Reporting of 14C Data. Radiocarbon 19(3), 3551267363.

1268 Swann, G.E., Leng, M.J., Juschus, O., Melles, M., Brigham-Grette, J., Sloane, H.J., 2010. A 1269 combined oxygen and silicon diatom isotope record of Late Quaternary change in Lake 1270 El'gygytgyn, North East Siberia, Quat. Sci. Rev. 29 (5-6), 2010, 774-786.

1271 Tomirdiaro, S.V., 1982. Evolution of Lowland Landscapes in Northeastern Asia during Late 1272 Quaternary Time. Paleoecol. Beringia, 29-42.

1273 Ulrich, M., Matthes, H., Schirrmeister, L., Schütze, J., Park, H., Iijima, Y., Fedorov, A.N., 1274 2017a. Differences in behavior and distribution of permafrost-related lakes in Central Yakutia 1275 and their response to climatic drivers. Water Resour. Res. 53(2), 1167-1188.

1276 Ulrich, M., Wetterich, S., Rudaya, N., Frolova, L., Schmidt, J., Siegert, C., Fedorov, A.N., 1277 Zielhofer, C., 2017b. Rapid thermokarst evolution during the mid-Holocene in Central Yakutia, 1278 Russia. The Holocene 27(12), 1899-1913.

1279 Veganzones, M.A., Grana, M., 2008. Endmember extraction methods: A short review, in: 1280 Lovrek, I., Howlett, R.J., Jain, L.C. (Eds.). KES 2008, Part III, LNAI 5179. Berlin, Heidelberg: 1281 Springer, pp. 400-407.

1282 Walter, K.M., Edwards, M.E., Grosse, G., Zimov, S.A., Chapin III, F.S., 2007. Thermokarst 1283 lakes as a source of atmospheric CH4 during the last deglaciation. Science 318, 633-636.

1284 Walter Anthony, K.M., Zimov, S.A., Grosse, G., Jones, M.C., Anthony, P.M., Chapin III, F.S., 1285 Finlay, J.C., Mack, M.C., Davydov, S., Frenzel, P., Frolking, S., 2014. A shift of thermokarst 1286 lakes from carbon sources to sinks during the Holocene epoch. Nature, 511, 452-456.

1287 Walter Anthony, K., Schneider von Deimling, T., Nitze, I., Frolking, S., Emond, A., Daanen, 1288 R., Anthony, P., Lindgren, P., Jones, B., Grosse, G., 2018. 21st-century modeled permafrost 1289 carbon emissions accelerated by abrupt thaw beneath lakes. Nature Com., 9:3262. 1290 DOI:10.1038/s41467-018-05738-9. 
1291 Weltje, G.J., Prins, M.A., 2003. Muddled or mixed? Inferring palaeoclimate from size 1292 distributions of deep-sea clastics. Sediment. Geol. 162(1-2), 39-62.

1293 Weltje, G.J., Prins, M.A., 2007, Genetically meaningful decomposition of grain-size 1294 distributions. Sediment. Geol. 202(3), 409- 424.

1295 Wetterich, S.. Schirrmeister, L., Pietrzeniuk, E., 2005. Freshwater ostracodes in Quaternary permafrost deposits in the Siberian Arctic. J Paleolim. 34(3), 363-376.

1297 Wetterich, S., Schirrmeister, L., Meyer, H., Siegert, C., 2008. Thermokarst lakes in Central 1298 Yakutia (Siberia) as habitats of freshwater ostracodes and archives of palaeoclimate, in: Kane, 1299 D.L., Hinkel, K.M. (Eds.), Ninth International Conference on Permafrost, University of Alaska 1300 Fairbanks, Institute of Northern Engineering, pp. 1945-1950.

1301 Wetterich, S., Grosse, G., Schirrmeister, L., Andreev, A.A., Bobrov, A.A., Kienast, F., Bigelow, 1302 N.H., Edwards, M.E., 2012. Late Quaternary environmental and landscape dynamics revealed 1303 by a pingo sequence on the northern Seward Peninsula, Alaska. Quat. Sci. Rev. 39, $26-44$.

1304 Windirsch, T., 2018. Organic Matter Characteristics in a Changing Permafrost Environment: 1305 Yukechi Alas Landscape, Central Yakutia. Master thesis, University of Potsdam, Germany, pp. 1306 39. Online available: http://epic.awi.de/48337/.

1307 Zielhofer, C., Fletcher, W.J., Mischke, S., De Batist, M., Campbell, J.F.E., Joannin, S., 1308 Tjallingii, R., El Hamouti, N., Junginger, A., Stele, A., Bussmann, J., Schneider, B., Lauer, T., 1309 Spitzer, K., Strupler, M., Brachert, T., Mikdad, A., 2017. Atlantic forcing of Western 1310 Mediterranean winter rain minima during the last 12,000 years. Quat. Sci. Rev. 157, 29-51.

1311 Zimov, S.A., Chuprynin, V.I., Oreshko, A.P., Chapin, F.S., Reynolds, J.F., Chapin, M.C., 1995. 1312 Steppe-Tundra Transition: A Herbivore-Driven Biome Shift at the End of the Pleistocene. The 1313 American Naturalist 146(5), 765-794. 

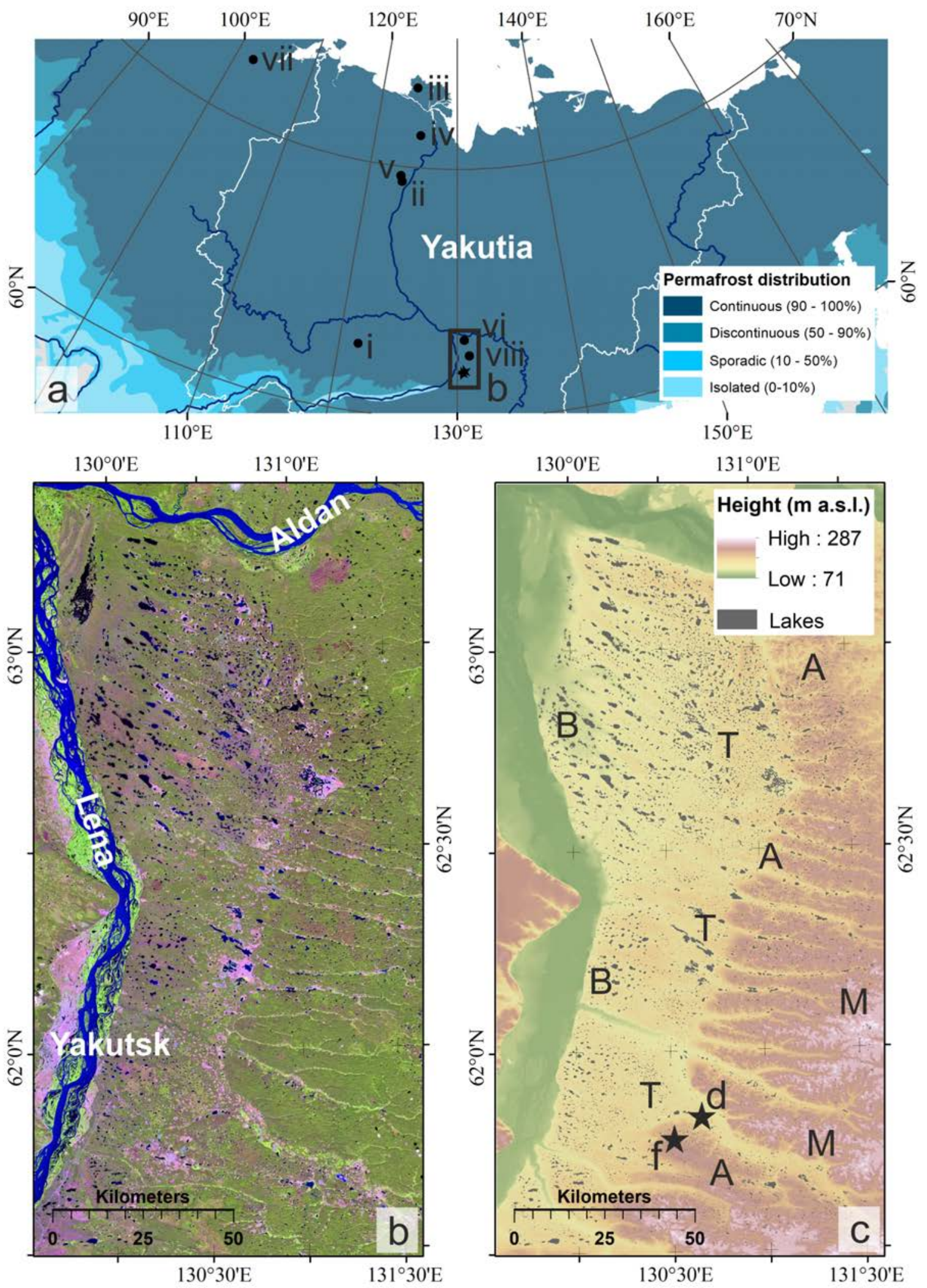

1317 Fig. 1. Study site overview. (a) Location of the study region and the key study sites (black stars) 1318 in the zone of continuous permafrost. Roman letters mark previous paleoenvironmental 
1319 reconstructions from thermokarst lake sediments in Siberia; i) Andreev et al. (1997), ii) 1320 Biskaborn et al. (2012), iii) Biskaborn et al. (2013a), iv) Biskaborn et al. (2013b) / Schleusner 1321 et al. (2014), v) Biskaborn et al. (2016), vi) Katamura et al. (2009), vii) Klemm et al., 2016, 1322 Popp et al. (2006). Map of permafrost distribution modified after Brown et al. (2002). (b) The 1323 Lena-Aldan interfluve region (Landsat 8 closeup, July 2013, USGS). (c) Thermokarst 1324 development and lake properties differ on several Pleistocene accumulative-erosive terraces 1325 following Soloviev (1959). B: Bestyakh terrace, T: Tyungyulyu terrace, A: Abalakh terrace, M: 1326 Magan terrace. In particular the Tyungyulyu and the Abalakh terraces are differentiated due to characteristics and distribution of ice-rich permafrost deposits. The stars are indicating the KB 1328 key study site (d) on the Tyungyulyu terrace and the YU key study site (f) on the Abalakh 1329 terraces. For details see Figure 2 (DEM generated using data from the ESA DUE Permafrost 1330 Project (Santoro and Strozzi, 2012)).
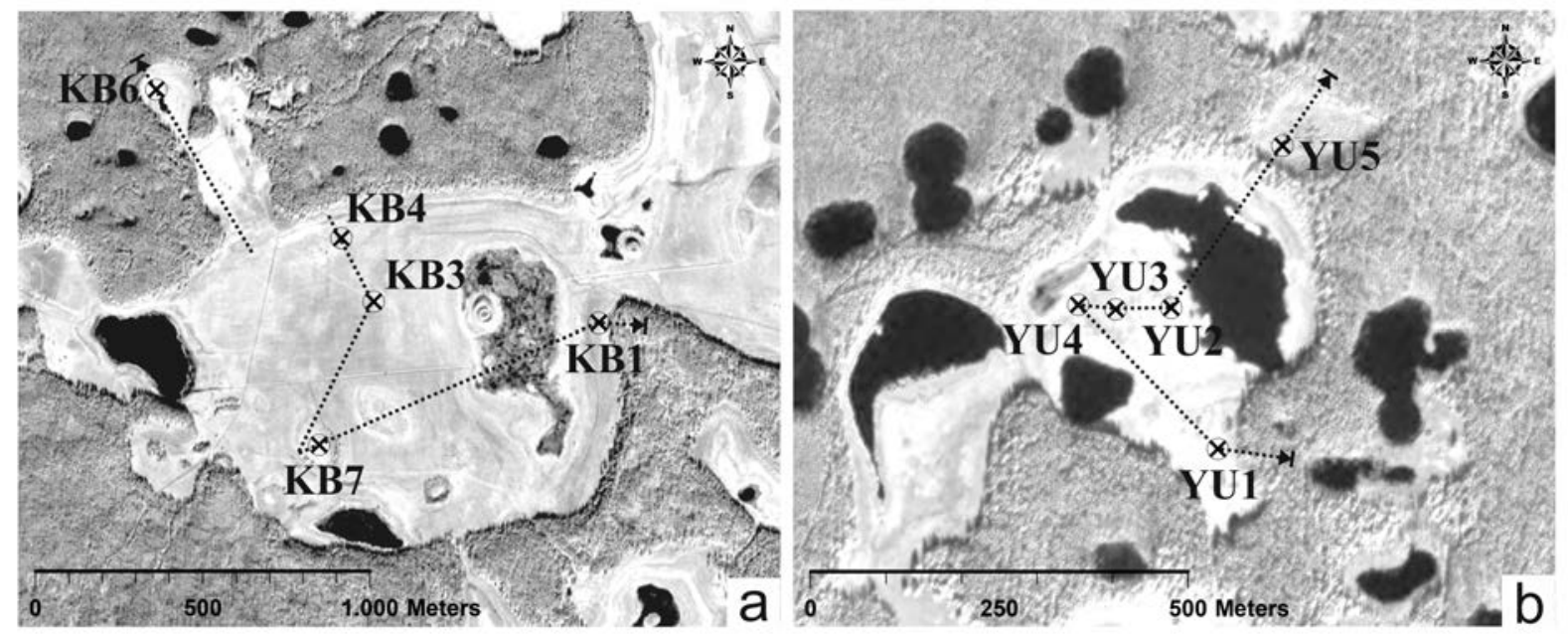

1334 Fig. 2. Satellite images showing the drilling sites within (a) the KB basin and (b) the YU basin 1335 (Pleiades-1A subsets, 22 Sept. 2012). The dashed lines mark the topographic profiles illustrated 1336 in Fig. 3. 

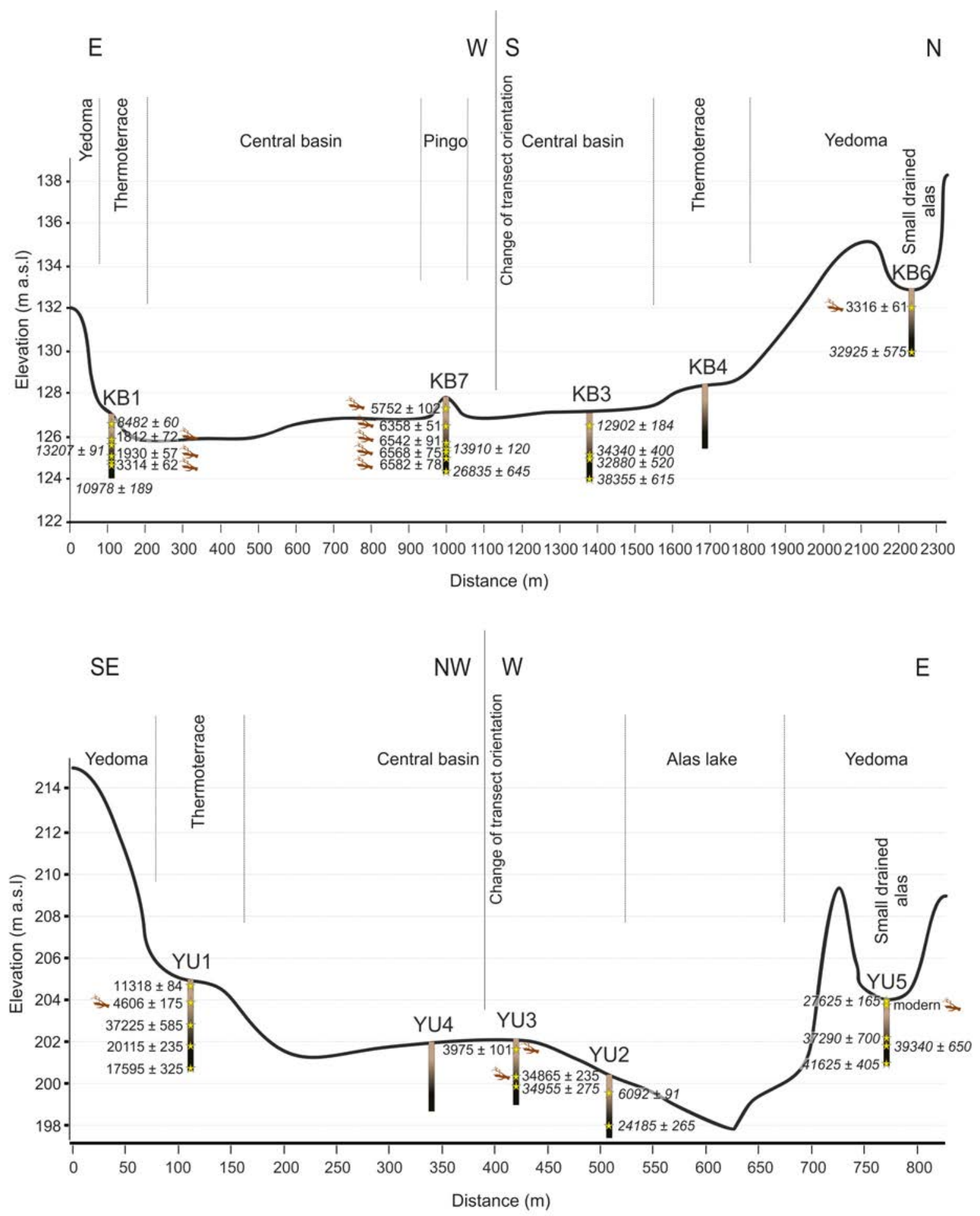

1339 Fig. 3. Coring transects of the studied thermokarst basin in relation to geomorphology and 1340 topography. Topographic data based on geodetic field surveys conducted in summer 2014 (see 1341 Ulrich et al., 2017a). The radiocarbon dates are shown as cal. yrs. BP for each dated core. The 1342 dating of bulk material is highlighted by italics and the macro remains are highlighted by the 1343 wooden stick symbols. 

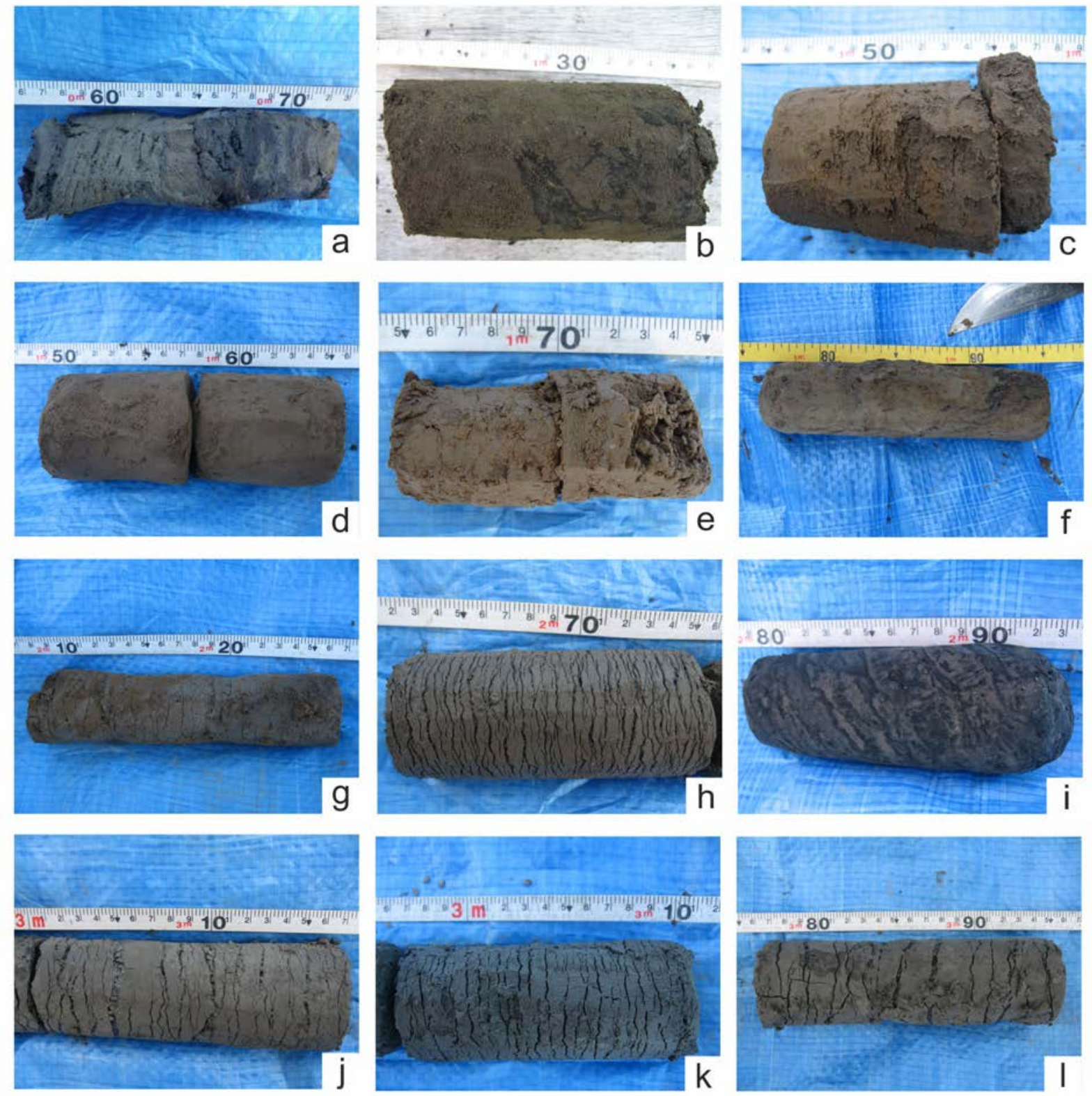

1345 Fig. 4. Example photos of sediment composition, color, and cryolithological properties as seen 1346 in the field from the different thermokarst deposit cores. (a) YU2, (b) KB7, (c) KB6, (d) YU5, 1347 (e) YU1 (f) KB1, (g) YU3, (h) YU1, (i) KB3, (j) YU1, (k) KB4, (1) YU1. Please see scales for 1348 sample depths. 

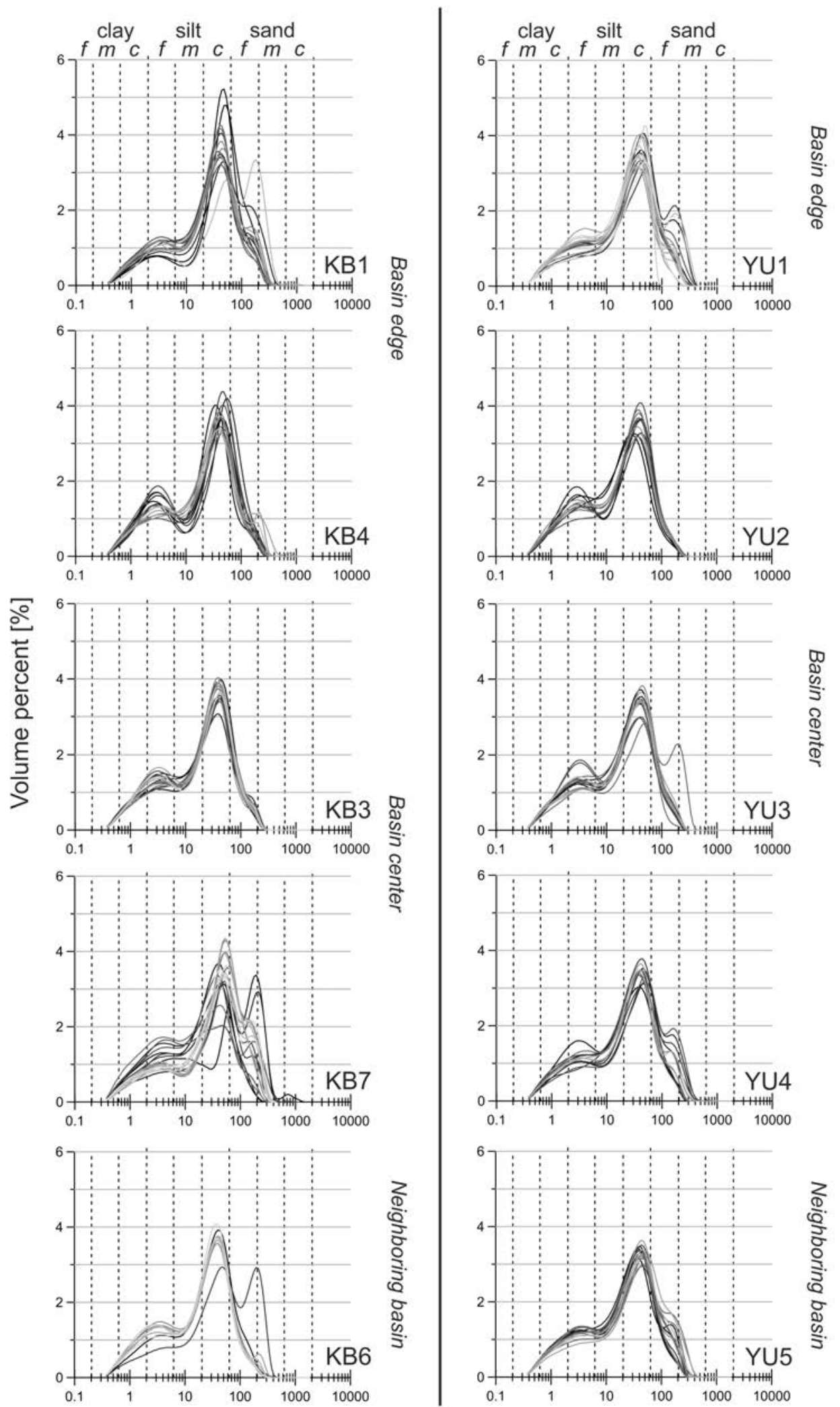

Grain size $[\mu \mathrm{m}]$

1351 Fig. 5. GSD curves of all thermokarst deposit cores with the KB study site (left) and the YU 1352 study site (right). The gray levels of the GSD curves decrease with core depth. Clay, silt, and 1353 sand are divided into fine (f), middle (m), and coarse (c) fractions. 

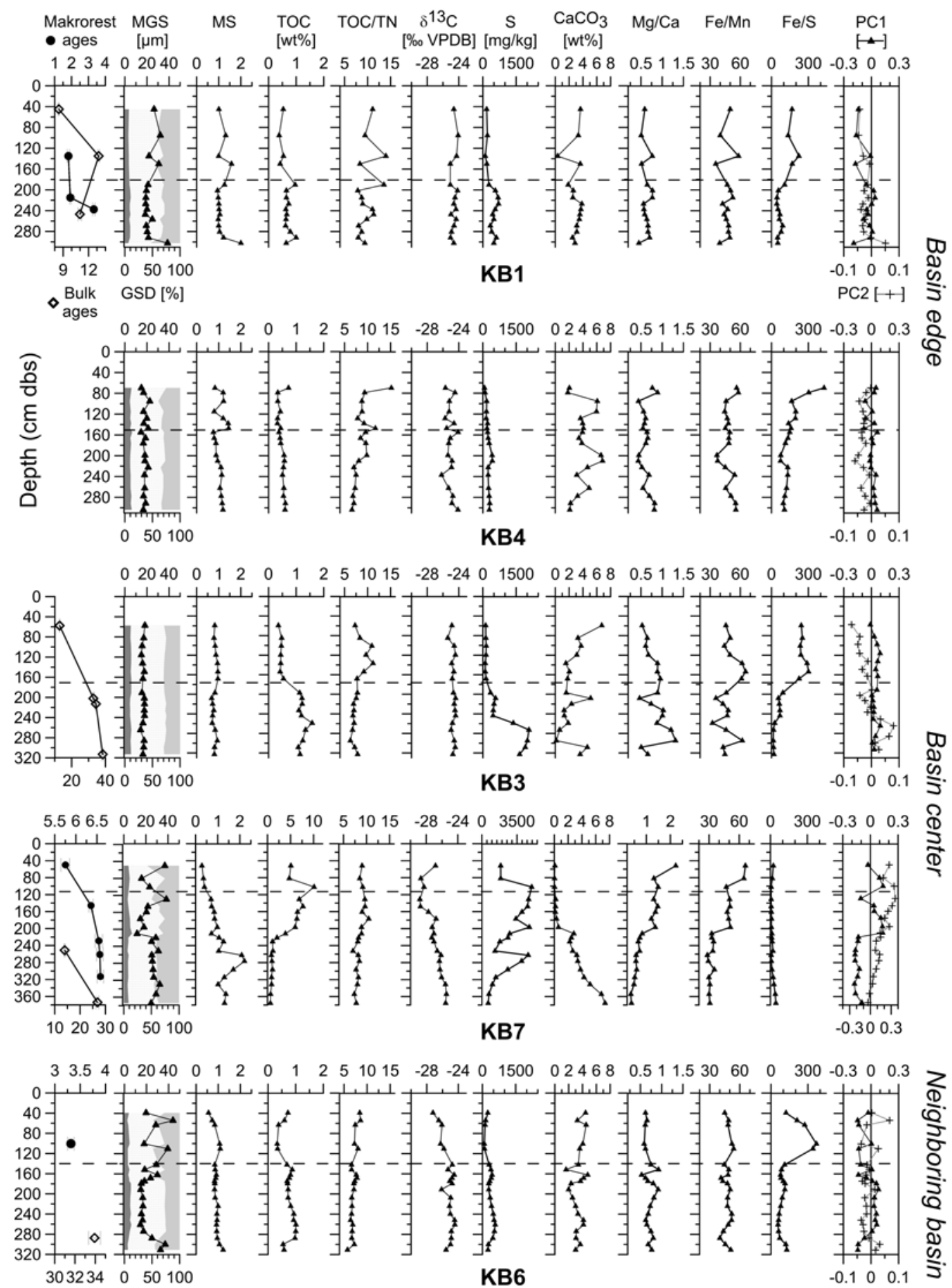

1355 Fig. 6. Sedimentological and biogeochemical results of all KB cores against sample depth with 1356 the macro remain and bulk ages in cal. kyrs. BP, the GSD including contents of clay (dark gray), 1357 silt (white), sand (light gray) and the grain-size mean as MGS, the MS in SI units (10-6 m3 kg1358 1), TOC, TOC/TN, $\delta 13 \mathrm{C}, \mathrm{CaCO}$, and selected elements and element ratios from XRF 1359 measurements. Additionally, the sample scores on PC1 and PC2 are plotted (See section 4.4). 1360 Please note the different scaling of the macro remain and bulk ages as well as TOC, S, and $1361 \mathrm{Mg} / \mathrm{Ca}$ values and the PC2 scores of KB7. The dashed horizontal lines mark the observed active 1362 layer depths. 

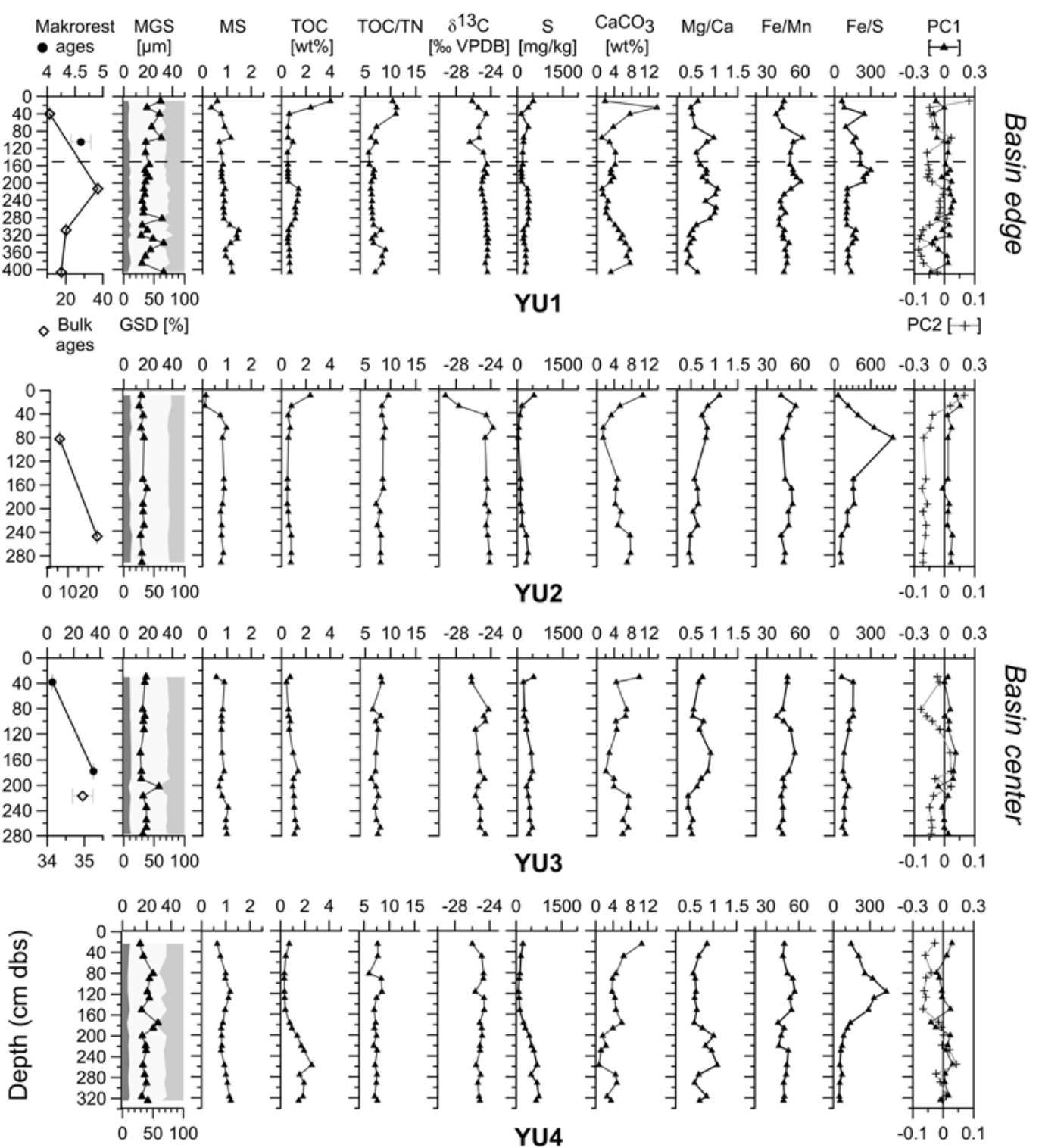

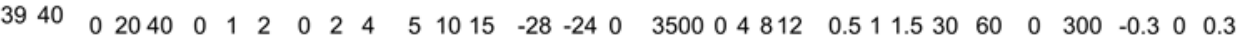

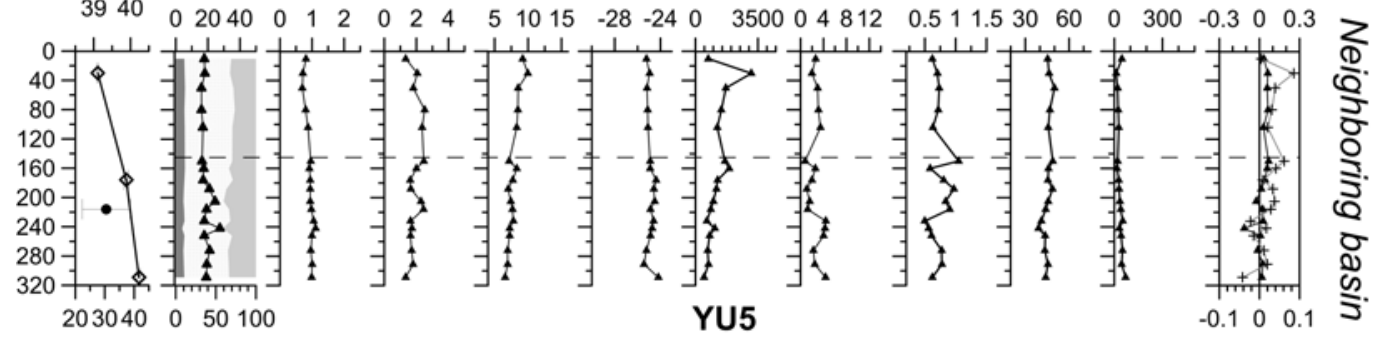

1364 Fig. 7. Sedimentological and biogeochemical results of all YU cores against sample depth with

1365 the macro remain and bulk ages in cal. kyrs. BP, the GSD including contents of clay (dark gray),

1366 silt (white), sand (light gray), and the grain-size mean as MGS, the MS in SI units (10-6 m3 kg-

1367 1), TOC, TOC/TN, $\delta 13 \mathrm{C}, \mathrm{CaCO} 3$, and selected elements and element ratios from XRF

1368 measurements. Additionally, the sample scores on PC1 and PC2 are plotted (See section 4.4).

1369 Please note the different scaling of the macro remain and bulk ages as well as of the $\mathrm{S}$ values 1370 of YU5, and the Fe/S values of YU2. The dashed horizontal lines mark the observed active 1371 layer depths. 

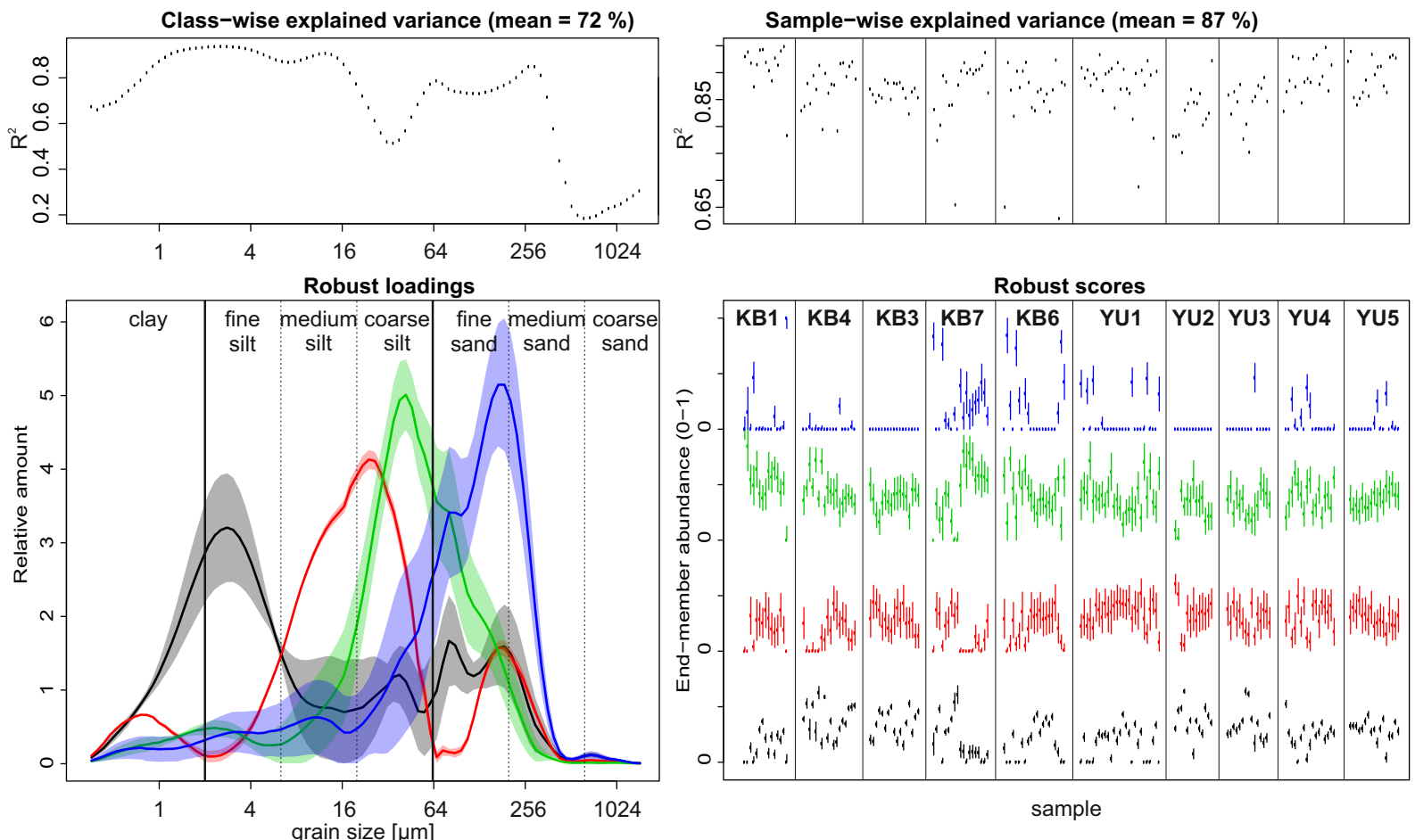

End-member ID (mode position | explained variance)

1373 Fig. 8. EMMA results from all input data showing final rEMs and their explained variances,

1374 class-wise explained variances, and sample-wise explained variances. The robust scores are 1375 plotted with their confidence intervals for each core in their stratigraphic order, i.e. from top 1376 (left) to bottom (right). 


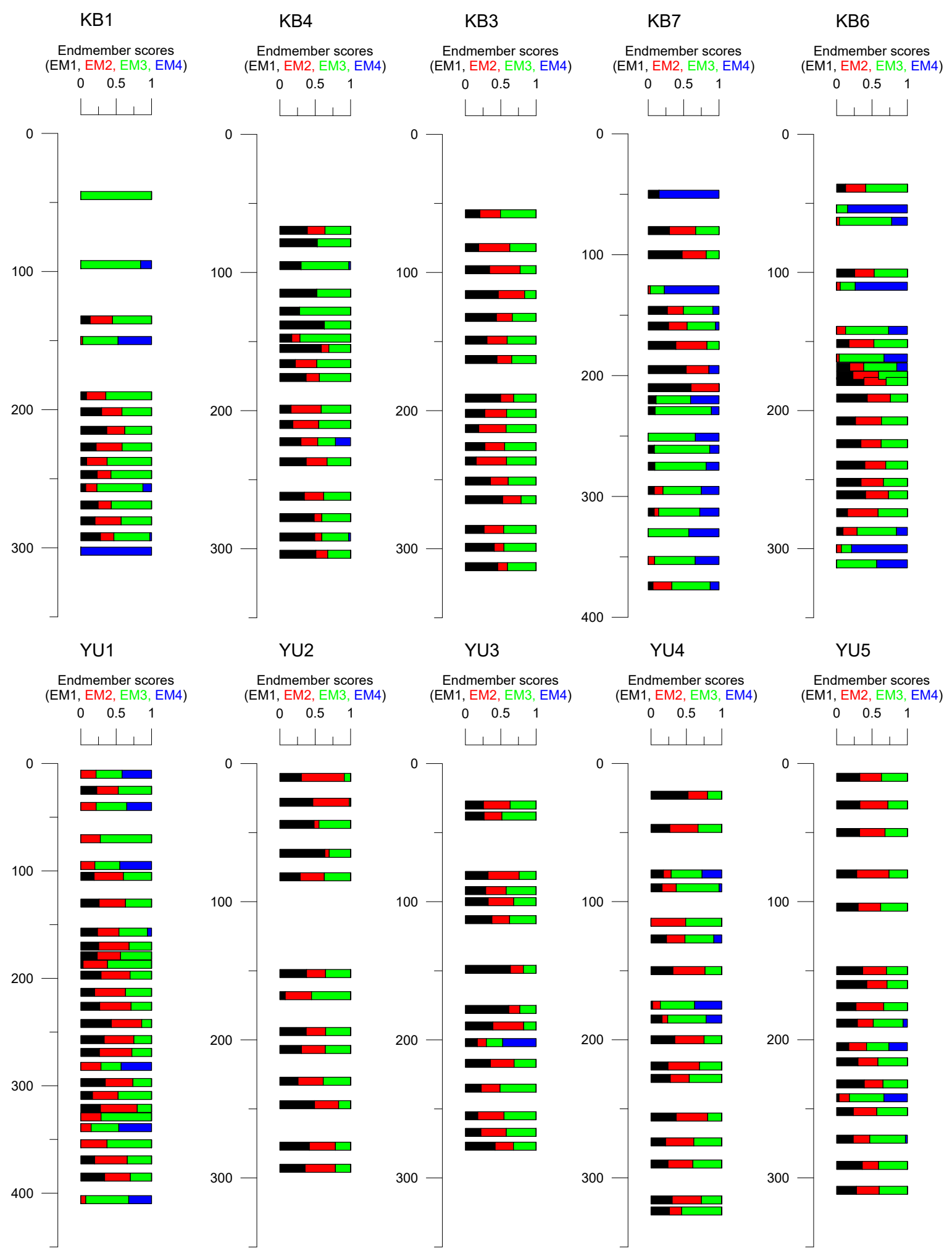

1379 Fig. 9. The mean scores (i.e. the relative contribution of an rEM to each sample) for all studied 1380 cores against depth. 


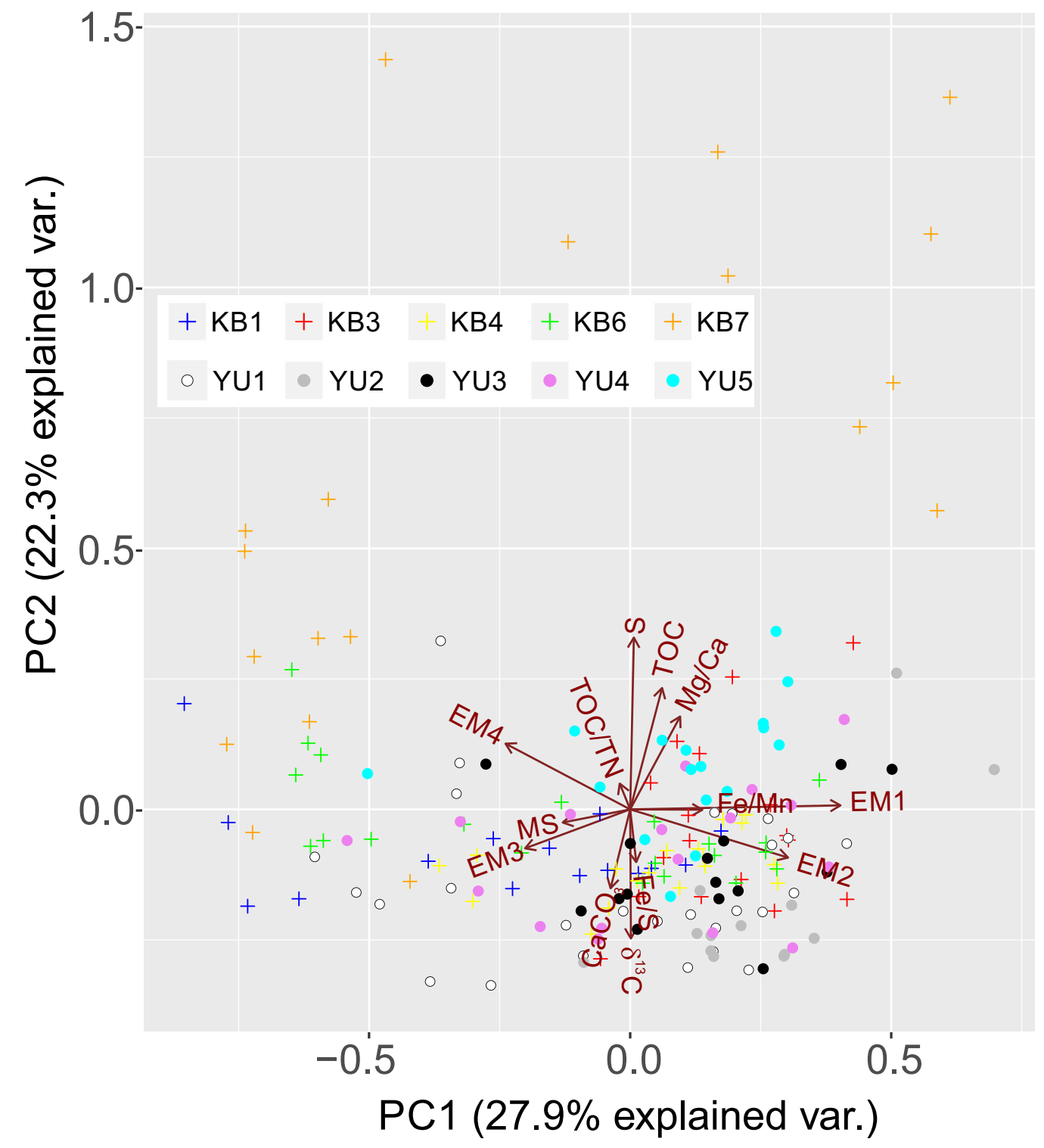

1384 Fig. 10. Ordination plot of the PCA on all rEM scores and biogeochemical parameters for PC1 1385 against PC2. For interpretation purposes, all core samples are additionally projected into the 1386 ordination graph. 


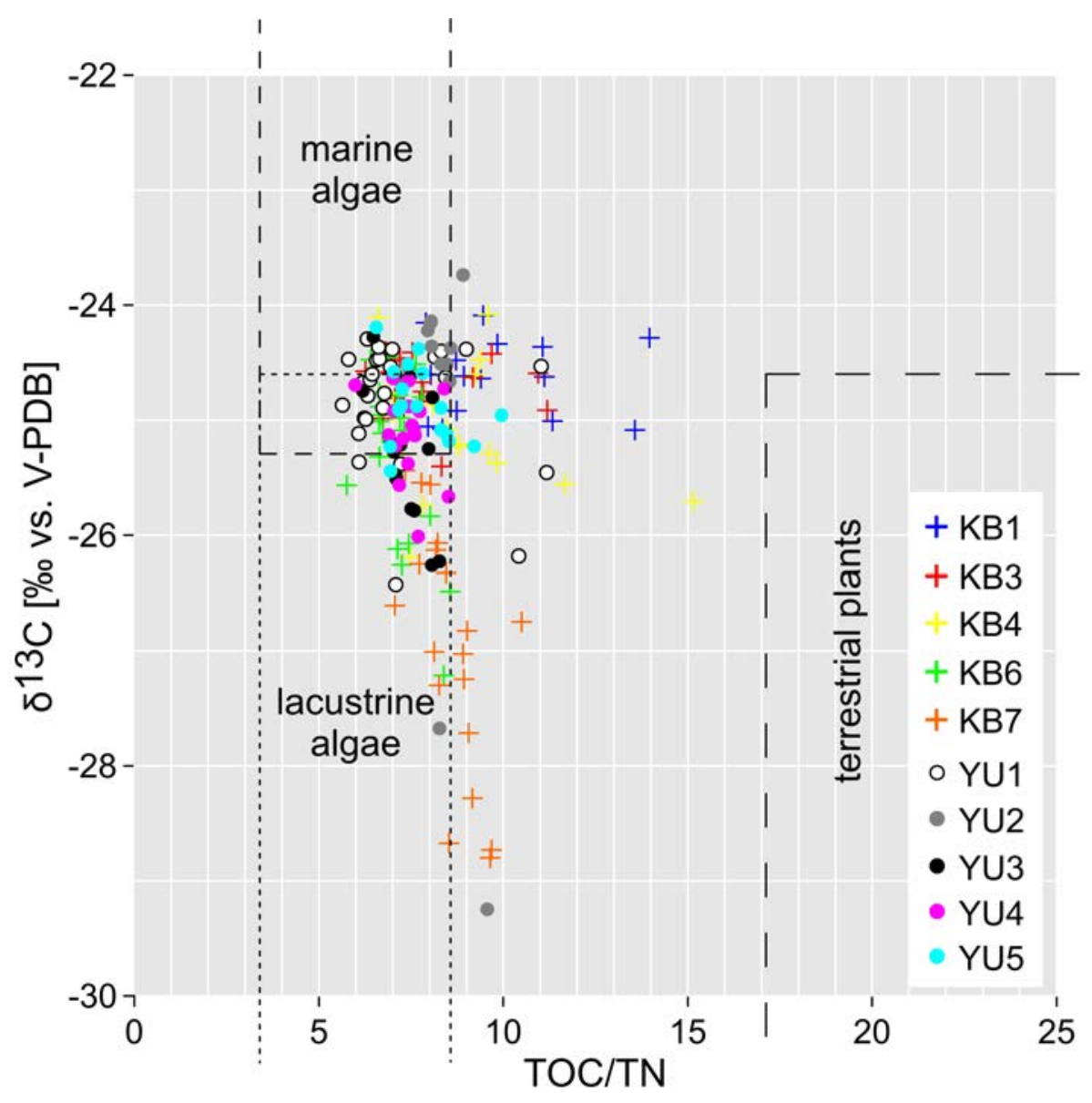

1389 Fig. 11. TOC/TN $-\delta 13 \mathrm{C}$ relationship for all core samples reflecting organic matter origin. The 1390 classification of organic matter source follows Meyers and Teranes (2001). 


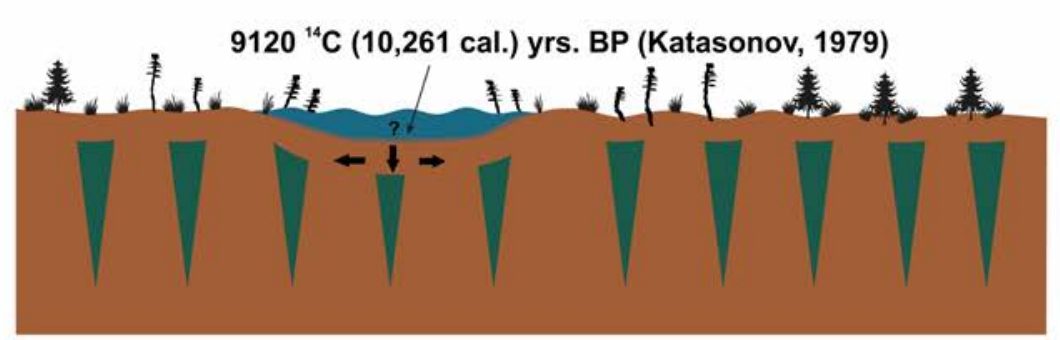

(A) Late Pleistocene / Early Holocene
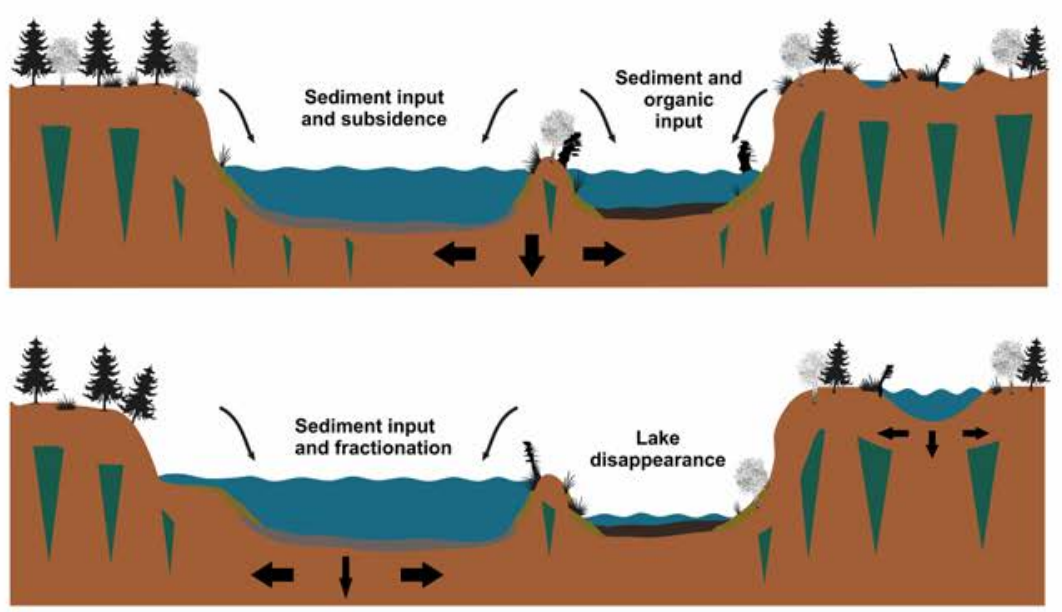

(B) 7000 - 5000 cal. yrs. BP (Climate optimum)

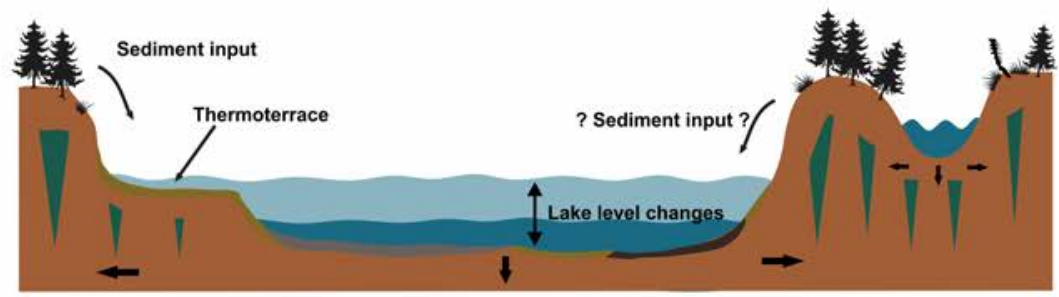

(C) 3500 - 1500 cal. yrs. BP

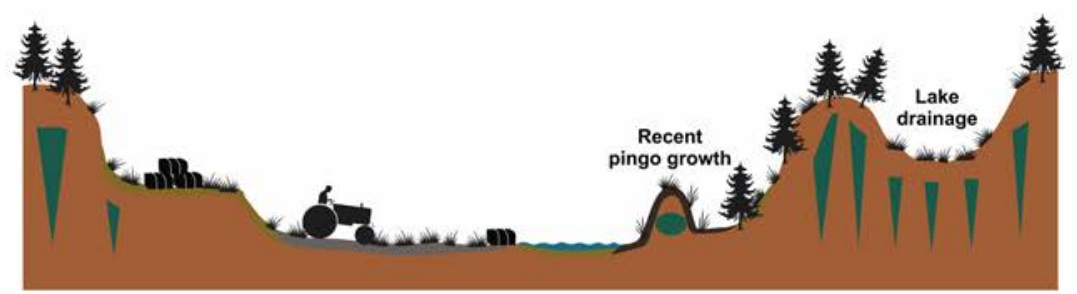

(D) 1500 cal. yrs. BP-present

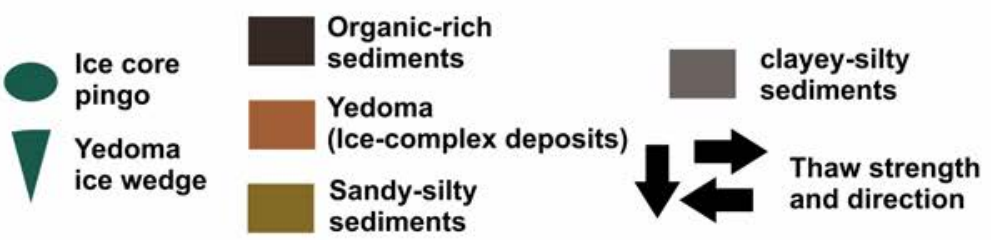

1393 Fig. 12. Schematic diagram showing the generalized thermokarst landscape evolution in CY as 1394 inferred from the sedimentology, biogeochemistry, and rEMMA analysis of the two studied 1395 thermokarst basins. Drawings are not to scale. 
1397 Tab. 1. Radiocarbon dating results used in this study are ordered due to the dated materials and 1398 depth. Dating differences of bulk organic material are additionally highlighted in italics. 1399 Calibrated ages refer to the $2 \sigma$ range.

\begin{tabular}{|c|c|c|c|c|c|c|c|}
\hline \multirow{2}{*}{$\begin{array}{l}\text { Lab ID } \\
\text { MAMS }\end{array}$} & \multirow{2}{*}{$\begin{array}{l}\text { Sample name } \\
\text { (including depth } \\
\text { in cm bs) }\end{array}$} & \multirow[b]{2}{*}{ Dated material } & \multicolumn{2}{|c|}{${ }^{14} \mathrm{C}$ ages } & \multirow{2}{*}{$\begin{array}{l}\delta^{13} \mathbf{C} \\
(\%)\end{array}$} & \multicolumn{2}{|c|}{ Calibrated ages } \\
\hline & & & yrs BP & $( \pm)$ & & $\begin{array}{c}\text { cal. yrs. } \\
\text { BP }\end{array}$ & $( \pm)$ \\
\hline \multicolumn{8}{|c|}{ KB Basin edge } \\
\hline 21300 & KB1 $145-125$ & Wood & 1890 & 19 & -32.9 & 1812.5 & 72.5 \\
\hline 23115 & KB1 222-208 & Plant remains & 1969 & 24 & -21.0 & 1930.5 & 57.5 \\
\hline 23116 & KB1 243-232 & Plant remains & 3091 & 25 & -22.6 & 3314 & 62 \\
\hline 21299 & KB1 55-35 & Bulk & 7698 & 27 & -28.4 & 8482 & 60 \\
\hline 21301 & KB1 145-125 (2) & Bulk & 11,317 & 32 & -24.7 & $13,207.5$ & 91.5 \\
\hline 21302 & KB1 250-244 & Bulk & 9619 & 28 & -24.5 & 1,0978 & 189 \\
\hline \multicolumn{8}{|c|}{ KB Basin center } \\
\hline 21303 & KB3 63-52 & Bulk & 11,024 & 37 & -24.2 & $12,902.5$ & 184.5 \\
\hline 23117 & KB3 205-199 & Bulk & 2,8550 & 120 & -29.1 & 32,877 & 527 \\
\hline 21304 & KB3 222-204 & Bulk & 29,660 & 120 & -31.0 & 34,340 & 400 \\
\hline 21305 & KB3 320-306 & Bulk & 33,660 & 160 & -31.1 & 38,355 & 615 \\
\hline 21306 & KB7 60 & Plant remains & 4984 & 24 & -26.3 & 5752 & 102 \\
\hline 21307 & KB7 154-137 & Wood & 5587 & 25 & -34.2 & 6358 & 51 \\
\hline 23120 & KB7 243-224 & Wood & 5735 & 27 & -15.5 & 6542 & 91 \\
\hline 23121 & KB7 285-265 & Wood & 5767 & 27 & -18.5 & 6568 & 75 \\
\hline 23122 & KB7 320-306 & Plant remains & 5790 & 27 & -15.5 & 6582 & 78 \\
\hline 21308 & KB7 264-258 & Bulk & 12060 & 40 & -30.0 & 13910 & 120 \\
\hline 21309 & KB7 382-365 & Bulk & 22,210 & 70 & -30.7 & 26,835 & 645 \\
\hline \multicolumn{8}{|c|}{ KB Neighboring small drained basin } \\
\hline 23118 & KB6 92 & Wood & 3093 & 25 & -29.5 & 3316 & 61 \\
\hline 23119 & KB6 295-280 & Bulk & 29,190 & 140 & -26.6 & 33,925 & 575 \\
\hline \multicolumn{8}{|c|}{ YU Basin edge } \\
\hline 23123 & YU1 110-100 & Plant remains & 4046 & 25 & -27.3 & 4606 & 175 \\
\hline 21310 & $Y U 150-30$ & Bulk & 9918 & 33 & -12.5 & 11318.5 & 84.5 \\
\hline 21311 & YU1 219-206 & Bulk & 32,670 & 150 & -28.7 & 37,225 & 585 \\
\hline 23124 & YU1 317-301 & Bulk & 16,930 & 60 & -28.8 & 20,115 & 235 \\
\hline 21312 & $Y U 1414-398$ & Bulk & 14,500 & 50 & -28.8 & 17,595 & 325 \\
\hline \multicolumn{8}{|c|}{ YU Basin center } \\
\hline 21313 & $Y U 291-76$ & Bulk & 5318 & 25 & -27.8 & 6092.5 & 91.5 \\
\hline 21314 & $Y U 2253-240$ & Bulk & 20,280 & 60 & -17.1 & 24,185 & 265 \\
\hline 23125 & YU3 40-36 & Charcoal & 3637 & 26 & -27.8 & 3975 & 102 \\
\hline 23126 & YU3 185-170 & Plant remains & 30,300 & 140 & -17.7 & 34,865 & 235 \\
\hline 23127 & YU3 226-208 & Bulk & 30,500 & 140 & -15.4 & 34,955 & 275 \\
\hline \multicolumn{8}{|c|}{ YU Neighboring small drained basin } \\
\hline 23128 & YU5 40-20 & Plant remains & -189 & 21 & -22.5 & modern & \\
\hline 23129 & YU5 222-210 & Plant remains & 34,280 & 200 & -18.6 & 39,340 & 650 \\
\hline 21315 & YU5 40-20 (2) & Bulk & 23,450 & 90 & -28.9 & 27,625 & 165 \\
\hline 21316 & YU5 183-170 & Bulk & 33,100 & 170 & -30.3 & 37,290 & 700 \\
\hline 21317 & YU5 318-300 & Bulk & 37,080 & 240 & -28.3 & 41,625 & 405 \\
\hline
\end{tabular}


Tab. 2. Robust grain-size endmembers, their characteristics, local source as well as transport and accumulation pathways.

\begin{tabular}{ccccc}
\hline $\begin{array}{c}\text { Final } \\
\text { EM }\end{array}$ & $\begin{array}{c}\text { Mode } \\
(\boldsymbol{\mu m})\end{array}$ & $\begin{array}{c}\text { Explained } \\
\text { variance } \\
(\mathbf{\%})\end{array}$ & Grain size & $\begin{array}{c}\text { Source, transport and accumulation } \\
\text { pathways }\end{array}$ \\
\hline rEM1 & 2.9 & 24 & $\begin{array}{c}\text { coarse clay to } \\
\text { very-fine silt }\end{array}$ & $\begin{array}{c}\text { distal, } \\
\text { homogenuous fractionation under } \\
\text { lacustrine thermokarst lake conditions } \\
\text { distal to proximal, }\end{array}$ \\
rEM2 & 27.4 & 18 & $\begin{array}{c}\text { medium to } \\
\text { coarse silt }\end{array}$ & $\begin{array}{c}\text { heterogenuous fractionation under } \\
\text { lacustrine thermokarst lake conditions } \\
\text { and Yedoma background signal }\end{array}$ \\
pM3 & 39.8 & 25 & $\begin{array}{c}\text { proximal, } \\
\text { coarse silt }\end{array}$ & $\begin{array}{c}\text { heterogenuous fractionation under } \\
\text { terrestrial conditions and Yedoma } \\
\text { background signal } \\
\text { in situ, }\end{array}$ \\
rEM4 & 176.8 & 32 & fine to & $\begin{array}{c}\text { medium sand } \\
\text { homogenuous fractionation due to } \\
\text { eroding lake shores and basin slopes }\end{array}$ \\
\hline
\end{tabular}


Supplementary data for

\title{
Holocene thermokarst dynamics in Central Yakutia - A multi-core and robust grain-size endmember modeling approach
}

\author{
Mathias Ulrich*, Heidrun Matthes, Johannes Schmidt, Alexander N. Fedorov, Lutz Schirrmeister, \\ Christine Siegert, Birgit Schneider, Jens Strauss, Christoph Zielhofer \\ *Corresponding author: Mathias Ulrich, Institute for Geography, Leipzig University, Johannisallee 19a, 04103 \\ Leipzig, Germany. Email: Mathias.Ulrich@uni-leipzig.de
}

\section{Appendix A.}

Additional sedimentological parameters, elements, and elemental ratios for all thermokarst deposit cores that were additionally used for interpretation and discussion of thermokarst (lake) processes.

\section{Appendix B.}

PCA ordination plots and explained PC variances on all robust EM scores and biogeochemical parameters for all PCs. For interpretation purposes, all core samples are additionally projected into the ordination graphs. 
Appendix A. Table S1. KB1

\begin{tabular}{|c|c|c|c|c|c|c|c|c|c|c|}
\hline $\begin{array}{c}\text { Depth } \\
{[\mathrm{cm} \text { bs] }}\end{array}$ & $\begin{array}{l}\text { Grain size } \\
\text { mean }[\mu \mathrm{m}]\end{array}$ & $\begin{array}{c}\text { Grain size } \\
\text { sorting } \\
\end{array}$ & $\begin{array}{c}\text { TIC } \\
{[\mathbf{w t} \%]}\end{array}$ & $\begin{array}{c}\text { TC } \\
{[w t \%]}\end{array}$ & $\begin{array}{c}\text { TN } \\
{[w t \%]}\end{array}$ & $\begin{array}{c}P \\
{[\mathrm{mg} / \mathrm{kg}]}\end{array}$ & $\begin{array}{c}\mathrm{Ca} \\
{[\mathrm{mg} / \mathrm{kg}]}\end{array}$ & $\begin{array}{c}\text { Mn } \\
{[\mathrm{mg} / \mathrm{kg}]}\end{array}$ & $\begin{array}{c}\text { Fe } \\
{[\mathrm{mg} / \mathrm{kg}]}\end{array}$ & $\begin{array}{c}\mathrm{Zr} \\
{[\mathrm{mg} / \mathrm{kg}]}\end{array}$ \\
\hline 45 & 26.4 & 3.9 & 0.4 & 1.0 & 0.0 & 843.8 & 27155.0 & 565.2 & 28260.0 & 389,6 \\
\hline 95 & 32.1 & 4.1 & 0.4 & 0.8 & 0.0 & 1131.0 & 29050.0 & 679.8 & 27280.0 & 455,95 \\
\hline 135 & 21.8 & 4.3 & 0.0 & 0.6 & 0.0 & 594.5 & 14825.0 & 426.7 & 24835.0 & 430,95 \\
\hline 150 & 30.7 & 5.0 & 0.4 & 0.9 & 0.0 & 1074.5 & 30480.0 & 822.0 & 29280.0 & 423,15 \\
\hline 190 & 20.9 & 4.2 & 0.2 & 1.2 & 0.1 & 836.4 & 22730.0 & 619.9 & 29155.0 & 426,75 \\
\hline 201.5 & 19.5 & 4.8 & 0.3 & 1.0 & 0.1 & 942.0 & 23445.0 & 628.4 & 31570.0 & 379,5 \\
\hline 215 & 19.0 & 4.9 & 0.3 & 1.0 & 0.1 & 926.4 & 23370.0 & 601.5 & 31610.0 & 372,85 \\
\hline 227 & 18.8 & 4.4 & 0.5 & 1.2 & 0.1 & 960.9 & 30455.0 & 717.2 & 30340.0 & 377,7 \\
\hline 237.5 & 20.1 & 4.2 & 0.4 & 1.1 & 0.0 & 857.0 & 29530.0 & 619.3 & 29395.0 & 395,9 \\
\hline 247 & 18.6 & 4.3 & 0.4 & 1.1 & 0.0 & 922.2 & 28425.0 & 685.6 & 30130.0 & 396,25 \\
\hline 256.5 & 24.8 & 4.7 & 0.4 & 1.0 & 0.1 & 892.6 & 28255.0 & 683.4 & 31460.0 & 366,15 \\
\hline 269 & 19.4 & 4.5 & 0.4 & 1.0 & 0.1 & 934.0 & 26090.0 & 642.3 & 31040.0 & 388,65 \\
\hline 280.5 & 20.2 & 4.7 & 0.4 & 1.2 & 0.1 & 988.7 & 26635.0 & 650.0 & 31300.0 & 369,65 \\
\hline 292 & 21.2 & 4.9 & 0.3 & 1.3 & 0.1 & 997.6 & 24420.0 & 611.0 & 30235.0 & 375,95 \\
\hline 302.5 & 38.5 & 5.5 & 0.3 & 1.0 & 0.1 & 961.4 & 32480.0 & 633.2 & 24980.0 & 345,75 \\
\hline $\min$ & 18.6 & 3.9 & 0.0 & 0.6 & 0.0 & 594.5 & 14825.0 & 426.7 & 24835.0 & 345,8 \\
\hline $\max$ & 38.5 & 5.5 & 0.5 & 1.3 & 0.1 & 1131.0 & 32480.0 & 822.0 & 31610.0 & 456,0 \\
\hline mean & 23.5 & 4.5 & 0.4 & 1.0 & 0.1 & 924.2 & 26489.7 & 639.0 & 29391.3 & 393,0 \\
\hline SD & 5.8 & 0.4 & 0.1 & 0.2 & 0.0 & 117.3 & 4197.6 & 81.3 & 2136.9 & 28,4 \\
\hline
\end{tabular}


Appendix A. Table S2. KB4

\begin{tabular}{|c|c|c|c|c|c|c|c|c|c|c|}
\hline $\begin{array}{c}\text { Depth } \\
{[\mathrm{cm} \text { bs] }}\end{array}$ & $\begin{array}{c}\text { Grain size } \\
\text { mean }[\mu \mathrm{m}]\end{array}$ & $\begin{array}{c}\text { Grain size } \\
\text { sorting } \\
\end{array}$ & $\begin{array}{c}\text { TIC } \\
{[\mathbf{w t} \%]}\end{array}$ & $\begin{array}{c}\text { TC } \\
{[w t \%]}\end{array}$ & $\begin{array}{c}\text { TN } \\
{[w t \%]}\end{array}$ & $\begin{array}{c}P \\
{[\mathrm{mg} / \mathrm{kg}]}\end{array}$ & $\begin{array}{c}\mathrm{Ca} \\
{[\mathrm{mg} / \mathrm{kg}]}\end{array}$ & $\begin{array}{c}\text { Mn } \\
{[\mathrm{mg} / \mathrm{kg}]}\end{array}$ & $\begin{array}{c}\mathrm{Fe} \\
{[\mathrm{mg} / \mathrm{kg}]}\end{array}$ & $\begin{array}{c}\mathrm{Zr} \\
{[\mathrm{mg} / \mathrm{kg}]}\end{array}$ \\
\hline 69.5 & 15.0 & 4.3 & 0.2 & 1.0 & 0.0 & 875.0 & 25175.0 & 536.1 & 30215.0 & 342,25 \\
\hline 78.5 & 16.9 & 4.5 & 0.2 & 0.5 & 0.0 & 933.4 & 19905.0 & 516.1 & 29980.0 & 421,5 \\
\hline 95 & 22.5 & 4.7 & 0.7 & 1.1 & 0.0 & 959.6 & 41715.0 & 609.3 & 27970.0 & 436,15 \\
\hline 115 & 17.0 & 4.5 & 0.7 & 1.1 & 0.0 & 891.3 & 34980.0 & 706.3 & 31445.0 & 329,35 \\
\hline 128 & 20.0 & 4.5 & 0.4 & 0.8 & 0.0 & 951.9 & 28215.0 & 634.0 & 29775.0 & 428,55 \\
\hline 138 & 17.0 & 4.8 & 0.5 & 0.8 & 0.0 & 971.1 & 29000.0 & 613.0 & 29500.0 & 430,6 \\
\hline 147.5 & 21.1 & 4.5 & 0.5 & 0.9 & 0.0 & 902.6 & 31050.0 & 668.3 & 30070.0 & 439,5 \\
\hline 155 & 14.5 & 4.6 & 0.5 & 0.8 & 0.0 & 868.7 & 25900.0 & 646.7 & 32075.0 & 350,4 \\
\hline 166 & 18.7 & 4.4 & 0.4 & 0.8 & 0.0 & 884.6 & 25230.0 & 651.1 & 31665.0 & 358,2 \\
\hline 176 & 16.8 & 4.4 & 0.5 & 0.9 & 0.0 & 912.1 & 28100.0 & 663.1 & 32190.0 & 366,05 \\
\hline 199 & 18.2 & 4.2 & 0.8 & 1.4 & 0.0 & 1001.5 & 41050.0 & 858.1 & 31565.0 & 360,95 \\
\hline 210 & 18.1 & 4.2 & 0.8 & 1.4 & 0.1 & 1039.5 & 42955.0 & 839.2 & 31490.0 & 347,55 \\
\hline 222.5 & 21.1 & 5.2 & 0.6 & 1.1 & 0.1 & 940.4 & 34055.0 & 697.2 & 31380.0 & 354,5 \\
\hline 237 & 17.8 & 4.8 & 0.4 & 0.9 & 0.1 & 927.4 & 25760.0 & 576.1 & 31325.0 & 354,8 \\
\hline 262 & 17.9 & 4.7 & 0.6 & 1.1 & 0.1 & 962.3 & 33155.0 & 697.3 & 31695.0 & 355,85 \\
\hline 277.5 & 16.9 & 4.9 & 0.4 & 0.9 & 0.1 & 973.0 & 25260.0 & 621.4 & 31470.0 & 353,95 \\
\hline 291.5 & 18.9 & 5.2 & 0.3 & 0.9 & 0.1 & 902.1 & 20535.0 & 537.3 & 29790.0 & 330,85 \\
\hline 304 & 16.8 & 5.1 & 0.3 & 0.8 & 0.1 & 931.4 & 21095.0 & 549.7 & 30570.0 & 363,85 \\
\hline $\min$ & 14.5 & 4.2 & 0.2 & 0.5 & 0.0 & 868.7 & 19905.0 & 516.1 & 27970.0 & 329,4 \\
\hline $\max$ & 22.5 & 5.2 & 0.8 & 1.4 & 0.1 & 1039.5 & 42955.0 & 858.1 & 32190.0 & 439,5 \\
\hline mean & 18.0 & 4.6 & 0.5 & 1.0 & 0.0 & 934.8 & 29618.6 & 645.5 & 30787.2 & 373,6 \\
\hline $\mathrm{SD}$ & 2.0 & 0.3 & 0.2 & 0.2 & 0.0 & 44.1 & 6907.1 & 91.3 & 1080.4 & 37,1 \\
\hline
\end{tabular}


Appendix A. Table S3. KB3

\begin{tabular}{|c|c|c|c|c|c|c|c|c|c|c|}
\hline $\begin{array}{c}\text { Depth } \\
{[\mathrm{cm} \text { bs] }}\end{array}$ & $\begin{array}{c}\text { Grain size } \\
\text { mean }[\mu \mathrm{m}]\end{array}$ & $\begin{array}{c}\text { Grain size } \\
\text { sorting } \\
\end{array}$ & $\begin{array}{c}\text { TIC } \\
{[\mathrm{wt} \%]}\end{array}$ & $\begin{array}{c}\text { TC } \\
{[w t \%]}\end{array}$ & $\begin{array}{c}\text { TN } \\
{[\mathbf{w t} \%]}\end{array}$ & $\begin{array}{c}P \\
{[\mathrm{mg} / \mathrm{kg}]}\end{array}$ & $\begin{array}{c}\mathrm{Ca} \\
{[\mathrm{mg} / \mathrm{kg}]}\end{array}$ & $\begin{array}{c}\text { Mn } \\
{[\mathrm{mg} / \mathrm{kg}]}\end{array}$ & $\begin{array}{c}\mathrm{Fe} \\
{[\mathrm{mg} / \mathrm{kg}]}\end{array}$ & $\begin{array}{c}\mathrm{Zr} \\
{[\mathrm{mg} / \mathrm{kg}]}\end{array}$ \\
\hline 57.5 & 18.1 & 4.3 & 0.8 & 1.2 & 0.0 & 845.0 & 37855.0 & 673.3 & 30770.0 & 379,6 \\
\hline 82 & 17.1 & 4.1 & 0.4 & 0.9 & 0.0 & 887.0 & 26735.0 & 662.4 & 33060.0 & 373,9 \\
\hline 98 & 15.6 & 4.3 & 0.4 & 0.9 & 0.0 & 1018.0 & 28205.0 & 795.5 & 35065.0 & 365,1 \\
\hline 116 & 15.0 & 4.6 & 0.4 & 0.8 & 0.0 & 887.3 & 24610.0 & 670.9 & 33365.0 & 363,1 \\
\hline 132.5 & 16.1 & 4.5 & 0.2 & 0.6 & 0.0 & 855.0 & 17405.0 & 517.0 & 31965.0 & 369,85 \\
\hline 149 & 17.5 & 4.5 & 0.2 & 0.7 & 0.0 & 842.6 & 18165.0 & 504.9 & 32915.0 & 375,45 \\
\hline 163 & 16.3 & 4.6 & 0.2 & 0.8 & 0.1 & 860.6 & 17015.0 & 533.9 & 32645.0 & 379,35 \\
\hline 191 & 15.5 & 4.5 & 0.2 & 1.3 & 0.1 & 895.3 & 18320.0 & 687.0 & 31610.0 & 385,9 \\
\hline 202 & 17.6 & 4.2 & 0.6 & 1.8 & 0.1 & 962.8 & 34670.0 & 904.2 & 32320.0 & 348,4 \\
\hline 213 & 17.8 & 4.1 & 0.3 & 1.5 & 0.2 & 974.8 & 22295.0 & 752.1 & 32230.0 & 380,1 \\
\hline 226 & 17.7 & 4.3 & 0.2 & 1.3 & 0.1 & 924.4 & 15650.0 & 672.5 & 32290.0 & 369,7 \\
\hline 236.5 & 17.8 & 4.0 & 0.2 & 1.3 & 0.1 & 943.5 & 16425.0 & 681.2 & 32025.0 & 379,6 \\
\hline 251 & 16.3 & 4.3 & 0.2 & 1.8 & 0.2 & 1056.5 & 18060.0 & 1095.0 & 35315.0 & 370,9 \\
\hline 264.5 & 14.2 & 4.3 & 0.1 & 1.4 & 0.2 & 967.3 & 12880.0 & 739.9 & 34005.0 & 374,75 \\
\hline 286 & 17.4 & 4.3 & 0.0 & 1.3 & 0.2 & 817.4 & 11685.0 & 486.5 & 30190.0 & 393,5 \\
\hline 299 & 17.1 & 4.5 & 0.6 & 1.6 & 0.1 & 1012.0 & 33480.0 & 747.2 & 32030.0 & 409,35 \\
\hline 313 & 16.3 & 4.5 & 0.4 & 1.6 & 0.1 & 1003.5 & 26230.0 & 702.1 & 31440.0 & 393,75 \\
\hline $\min$ & 14.2 & 4.0 & 0.0 & 0.6 & 0.0 & 817.4 & 11685.0 & 486.5 & 30190.0 & 348,4 \\
\hline $\max$ & 18.1 & 4.6 & 0.8 & 1.8 & 0.2 & 1056.5 & 37855.0 & 1095.0 & 35315.0 & 409,4 \\
\hline mean & 16.7 & 4.4 & 0.3 & 1.2 & 0.1 & 926.6 & 22334.4 & 695.6 & 32543.5 & 377,2 \\
\hline SD & 1.1 & 0.2 & 0.2 & 0.4 & 0.1 & 70.0 & 7585.7 & 145.9 & 1308.8 & 13,3 \\
\hline
\end{tabular}


Appendix A. Table S4. KB7

\begin{tabular}{|c|c|c|c|c|c|c|c|c|c|c|}
\hline $\begin{array}{c}\text { Depth } \\
{[\mathrm{cm} \text { bs] }}\end{array}$ & $\begin{array}{l}\text { Grain size } \\
\text { mean }[\mu \mathrm{m}]\end{array}$ & $\begin{array}{c}\text { Grain size } \\
\text { sorting } \\
\end{array}$ & $\begin{array}{c}\text { TIC } \\
{[w t \%]}\end{array}$ & $\begin{array}{c}\text { TC } \\
{[w t \%]}\end{array}$ & $\begin{array}{c}\text { TN } \\
{[\mathbf{w t} \%]}\end{array}$ & $\begin{array}{c}P \\
{[\mathrm{mg} / \mathrm{kg}]}\end{array}$ & $\begin{array}{c}\mathrm{Ca} \\
{[\mathrm{mg} / \mathrm{kg}]}\end{array}$ & $\begin{array}{c}\text { Mn } \\
{[\mathrm{mg} / \mathrm{kg}]}\end{array}$ & $\begin{array}{c}\text { Fe } \\
{[\mathrm{mg} / \mathrm{kg}]}\end{array}$ & $\begin{array}{c}\mathrm{Zr} \\
{[\mathrm{mg} / \mathrm{kg}]}\end{array}$ \\
\hline 50 & 37.1 & 6.1 & 0.0 & 5.1 & 0.5 & 2318.5 & 8891.5 & 649.6 & 42975.0 & 179,25 \\
\hline 80 & 16.1 & 4.2 & 0.0 & 4.7 & 0.5 & 1083.5 & 10810.0 & 433.7 & 27995.0 & 320,3 \\
\hline 100 & 23.3 & 5.0 & 0.0 & 10.1 & 0.9 & 1030.5 & 10970.0 & 553.9 & 26085.0 & 285,1 \\
\hline 129 & 38.5 & 5.3 & 0.0 & 6.9 & 0.6 & 1111.0 & 12860.0 & 547.4 & 27570.0 & 335 \\
\hline 146 & 21.8 & 4.7 & 0.0 & 7.7 & 0.7 & 1302.0 & 11905.0 & 579.6 & 29445.0 & 286,95 \\
\hline 159 & 20.6 & 4.9 & 0.0 & 6.5 & 0.6 & 1641.5 & 11950.0 & 618.1 & 29680.0 & 301,5 \\
\hline 175 & 15.0 & 4.4 & 0.0 & 6.4 & 0.5 & 1449.5 & 13990.0 & 585.2 & 28960.0 & 303,1 \\
\hline 195 & 18.3 & 5.8 & 0.1 & 6.1 & 0.6 & 1893.5 & 12690.0 & 669.4 & 34290.0 & 225,55 \\
\hline 210 & 11.9 & 4.7 & 0.3 & 4.2 & 0.4 & 1924.5 & 21450.0 & 1024.0 & 33350.0 & 247,4 \\
\hline 220 & 28.9 & 5.1 & 0.3 & 2.4 & 0.2 & 1543.0 & 23265.0 & 875.7 & 28695.0 & 386,35 \\
\hline 229 & 25.0 & 4.6 & 0.3 & 1.4 & 0.1 & 1245.5 & 23535.0 & 758.4 & 26135.0 & 447,05 \\
\hline 251 & 31.2 & 4.6 & 0.3 & 1.5 & 0.1 & 1096.0 & 23260.0 & 811.2 & 27355.0 & 365,5 \\
\hline 261 & 25.2 & 4.6 & 0.4 & 1.2 & 0.1 & 1147.5 & 26610.0 & 1048.0 & 29585.0 & 330,35 \\
\hline 275 & 25.9 & 4.6 & 0.4 & 1.4 & 0.1 & 1189.0 & 28885.0 & 1029.0 & 30165.0 & 386 \\
\hline 295 & 26.4 & 4.8 & 0.5 & 1.5 & 0.1 & 1086.5 & 29495.0 & 879.0 & 30985.0 & 372,8 \\
\hline 313 & 27.1 & 4.9 & 0.5 & 1.4 & 0.1 & 1236.5 & 33480.0 & 1006.0 & 29980.0 & 443,45 \\
\hline 330 & 32.6 & 4.7 & 0.6 & 1.5 & 0.1 & 1163.0 & 36095.0 & 969.1 & 29885.0 & 381,9 \\
\hline 353 & 29.1 & 4.8 & 0.8 & 1.5 & 0.1 & 1293.5 & 47205.0 & 923.0 & 27740.0 & 381,2 \\
\hline 374 & 24.7 & 4.8 & 0.9 & 1.5 & 0.1 & 1202.0 & 47790.0 & 925.3 & 28515.0 & 390,6 \\
\hline $\min$ & 11.9 & 4.2 & 0.0 & 1.2 & 0.1 & 1030.5 & 8891.5 & 433.7 & 26085.0 & 179,3 \\
\hline $\max$ & 38.5 & 6.1 & 0.9 & 10.1 & 0.9 & 2318.5 & 47790.0 & 1048.0 & 42975.0 & 447,1 \\
\hline mean & 25.2 & 4.9 & 0.3 & 3.8 & 0.3 & 1366.2 & 22901.9 & 783.4 & 29967.9 & 335,2 \\
\hline $\mathrm{SD}$ & 6.8 & 0.4 & 0.3 & 2.7 & 0.3 & 340.9 & 11702.7 & 192.0 & 3676.6 & 69,0 \\
\hline
\end{tabular}


Appendix A. Table S5. KB6

\begin{tabular}{|c|c|c|c|c|c|c|c|c|c|c|}
\hline $\begin{array}{c}\text { Depth } \\
{[\mathrm{cm} \text { bs] }}\end{array}$ & $\begin{array}{c}\text { Grain size } \\
\text { mean }[\mu \mathrm{m}]\end{array}$ & $\begin{array}{c}\text { Grain size } \\
\text { sorting } \\
\end{array}$ & $\begin{array}{c}\text { TIC } \\
{[\mathbf{w t} \%]}\end{array}$ & $\begin{array}{c}\text { TC } \\
{[w t \%]}\end{array}$ & $\begin{array}{c}\text { TN } \\
{[w t \%]}\end{array}$ & $\begin{array}{c}P \\
{[\mathrm{mg} / \mathrm{kg}]}\end{array}$ & $\begin{array}{c}\mathrm{Ca} \\
{[\mathrm{mg} / \mathrm{kg}]}\end{array}$ & $\begin{array}{c}\text { Mn } \\
{[\mathrm{mg} / \mathrm{kg}]}\end{array}$ & $\begin{array}{c}\mathrm{Fe} \\
{[\mathrm{mg} / \mathrm{kg}]}\end{array}$ & $\begin{array}{c}\mathrm{Zr} \\
{[\mathrm{mg} / \mathrm{kg}]}\end{array}$ \\
\hline 39 & 19.7 & 4.1 & 0.5 & 1.3 & 0.1 & 869.3 & 28645.0 & 656.9 & 29540.0 & 361,65 \\
\hline 54 & 44.0 & 4.6 & 0.4 & 1.0 & 0.1 & 1039.0 & 27295.0 & 647.5 & 31680.0 & 380,1 \\
\hline 63 & 28.4 & 4.5 & 0.5 & 0.9 & 0.0 & 996.7 & 28785.0 & 661.9 & 31905.0 & 364,85 \\
\hline 100.5 & 17.9 & 4.2 & 0.5 & 0.8 & 0.0 & 972.9 & 28910.0 & 609.2 & 31725.0 & 374,95 \\
\hline 110 & 39.3 & 5.0 & 0.4 & 0.8 & 0.0 & 933.7 & 27110.0 & 589.8 & 31845.0 & 376,8 \\
\hline 142 & 28.8 & 4.5 & 0.4 & 1.1 & 0.1 & 837.7 & 24370.0 & 757.7 & 33705.0 & 355,55 \\
\hline 151.5 & 18.3 & 4.1 & 0.2 & 1.1 & 0.1 & 873.5 & 18110.0 & 671.9 & 32990.0 & 368,4 \\
\hline 162 & 29.8 & 4.6 & 0.6 & 1.4 & 0.1 & 1009.7 & 34040.0 & 704.9 & 33975.0 & 366,25 \\
\hline 168.5 & 23.6 & 4.9 & 0.5 & 1.3 & 0.1 & 977.1 & 29415.0 & 782.9 & 32385.0 & 369,65 \\
\hline 174.5 & 18.1 & 4.2 & 0.4 & 1.1 & 0.1 & 906.4 & 26275.0 & 758.4 & 32645.0 & 359,05 \\
\hline 179 & 15.4 & 4.4 & 0.3 & 1.0 & 0.1 & 844.9 & 19965.0 & 692.2 & 33055.0 & 367 \\
\hline 191 & 14.8 & 4.3 & 0.2 & 1.0 & 0.1 & 887.9 & 18020.0 & 647.5 & 32605.0 & 372,05 \\
\hline 207.5 & 16.6 & 4.3 & 0.3 & 1.0 & 0.1 & 938.6 & 20555.0 & 663.2 & 31740.0 & 368,7 \\
\hline 224 & 16.9 & 4.4 & 0.4 & 1.2 & 0.1 & 947.0 & 23740.0 & 672.6 & 32085.0 & 390,85 \\
\hline 239.5 & 15.3 & 4.4 & 0.4 & 1.3 & 0.1 & 985.7 & 24995.0 & 625.6 & 32460.0 & 360,4 \\
\hline 252 & 16.4 & 4.2 & 0.5 & 1.4 & 0.1 & 1022.5 & 28365.0 & 619.5 & 32070.0 & 360,45 \\
\hline 261 & 14.5 & 4.4 & 0.5 & 1.5 & 0.1 & 1042.5 & 27205.0 & 668.8 & 32405.0 & 371,15 \\
\hline 274 & 17.3 & 4.0 & 0.4 & 1.4 & 0.1 & 1030.5 & 23650.0 & 758.2 & 33020.0 & 368,45 \\
\hline 287.5 & 24.9 & 4.7 & 0.4 & 1.3 & 0.1 & 1017.1 & 22625.0 & 835.9 & 33575.0 & 372,3 \\
\hline 300 & 37.0 & 4.9 & 0.4 & 1.0 & 0.1 & 951.5 & 25525.0 & 709.5 & 32385.0 & 359,8 \\
\hline 311 & 32.7 & 4.6 & 0.4 & 0.9 & 0.1 & 1005.0 & 22540.0 & 646.4 & 33015.0 & 355,55 \\
\hline $\min$ & 14.5 & 4.0 & 0.2 & 0.8 & 0.0 & 837.7 & 18020.0 & 589.8 & 29540.0 & 355,6 \\
\hline $\max$ & 44.0 & 5.0 & 0.6 & 1.5 & 0.1 & 1042.5 & 34040.0 & 835.9 & 33975.0 & 390,9 \\
\hline mean & 23.3 & 4.4 & 0.4 & 1.1 & 0.1 & 956.6 & 25244.8 & 684.8 & 32419.5 & 367,8 \\
\hline $\mathrm{SD}$ & 8.7 & 0.3 & 0.1 & 0.2 & 0.0 & 63.7 & 3948.9 & 61.2 & 914.2 & 8,4 \\
\hline
\end{tabular}


Appendix A. Table S6. YU1

\begin{tabular}{|c|c|c|c|c|c|c|c|c|c|c|}
\hline $\begin{array}{c}\text { Depth } \\
{[\mathrm{cm} \text { bs] }}\end{array}$ & $\begin{array}{l}\text { Grain size } \\
\text { mean }[\mu \mathrm{m}]\end{array}$ & $\begin{array}{c}\text { Grain size } \\
\text { sorting } \\
\end{array}$ & $\begin{array}{c}\text { TIC } \\
{[\mathbf{w t} \%]}\end{array}$ & $\begin{array}{c}\text { TC } \\
{[w t \%]}\end{array}$ & $\begin{array}{c}\text { TN } \\
{[w t \%]}\end{array}$ & $\begin{array}{c}P \\
{[\mathrm{mg} / \mathrm{kg}]}\end{array}$ & $\begin{array}{c}\mathrm{Ca} \\
{[\mathrm{mg} / \mathrm{kg}]}\end{array}$ & $\begin{array}{c}\text { Mn } \\
{[\mathrm{mg} / \mathrm{kg}]}\end{array}$ & $\begin{array}{c}\text { Fe } \\
{[\mathrm{mg} / \mathrm{kg}]}\end{array}$ & $\begin{array}{c}\mathrm{Zr} \\
{[\mathrm{mg} / \mathrm{kg}]}\end{array}$ \\
\hline 10 & 30.2 & 5.0 & 0.2 & 4.2 & 0.3 & 1611.0 & 24100.0 & 690.3 & 31245.0 & 323,8 \\
\hline 25 & 19.0 & 4.5 & 1.7 & 4.1 & 0.2 & 1004.3 & 62715.0 & 658.9 & 28580.0 & 293,05 \\
\hline 40 & 29.3 & 4.9 & 0.9 & 1.5 & 0.0 & 781.8 & 43865.0 & 855.5 & 32725.0 & 334,95 \\
\hline 70 & 23.0 & 4.0 & 0.5 & 1.0 & 0.1 & 863.9 & 29710.0 & 741.4 & 32940.0 & 373,35 \\
\hline 95 & 30.7 & 5.0 & 0.1 & 0.7 & 0.1 & 927.4 & 17340.0 & 581.3 & 36140.0 & 359,45 \\
\hline 105 & 18.3 & 4.4 & 0.3 & 1.3 & 0.1 & 937.5 & 22815.0 & 586.8 & 31470.0 & 341,4 \\
\hline 130 & 17.9 & 4.5 & 0.5 & 1.0 & 0.1 & 962.4 & 29625.0 & 715.2 & 36505.0 & 346,4 \\
\hline 157 & 21.1 & 4.9 & 0.5 & 1.0 & 0.1 & 1067.5 & 28790.0 & 736.0 & 37335.0 & 343,65 \\
\hline 170 & 17.4 & 4.5 & 0.4 & 0.9 & 0.1 & 902.3 & 24010.0 & 685.6 & 36620.0 & 338,45 \\
\hline 179 & 18.5 & 4.6 & 0.4 & 0.9 & 0.1 & 924.7 & 23950.0 & 672.2 & 36040.0 & 349,6 \\
\hline 187 & 21.1 & 4.1 & 0.5 & 1.0 & 0.1 & 891.5 & 25765.0 & 609.7 & 34545.0 & 349,15 \\
\hline 197 & 17.9 & 4.7 & 0.4 & 0.9 & 0.1 & 855.5 & 22155.0 & 558.9 & 33880.0 & 337,35 \\
\hline 213 & 16.6 & 3.9 & 0.1 & 1.5 & 0.2 & 828.3 & 16060.0 & 661.1 & 34060.0 & 347,15 \\
\hline 226 & 17.4 & 4.5 & 0.2 & 1.5 & 0.2 & 949.5 & 16605.0 & 796.2 & 36135.0 & 342,2 \\
\hline 242 & 15.0 & 4.4 & 0.3 & 1.6 & 0.2 & 990.8 & 21445.0 & 867.6 & 36320.0 & 351,1 \\
\hline 257 & 16.4 & 4.5 & 0.3 & 1.4 & 0.2 & 951.7 & 17465.0 & 842.7 & 36370.0 & 355,75 \\
\hline 269 & 16.1 & 4.3 & 0.2 & 1.4 & 0.2 & 953.8 & 17625.0 & 767.4 & 35785.0 & 369,7 \\
\hline 282 & 31.4 & 5.0 & 0.3 & 1.4 & 0.1 & 969.5 & 20200.0 & 870.9 & 35865.0 & 353,7 \\
\hline 297 & 15.2 & 4.2 & 0.5 & 1.3 & 0.1 & 883.4 & 28880.0 & 798.4 & 32705.0 & 355,5 \\
\hline 309 & 19.4 & 4.4 & 0.6 & 1.1 & 0.1 & 909.2 & 32945.0 & 743.6 & 33920.0 & 352,85 \\
\hline 321 & 14.3 & 3.9 & 0.7 & 1.3 & 0.1 & 916.3 & 37190.0 & 763.1 & 33820.0 & 344,8 \\
\hline 329 & 24.1 & 3.9 & 0.6 & 1.1 & 0.1 & 892.9 & 33065.0 & 760.9 & 34200.0 & 348,85 \\
\hline 339 & 32.7 & 5.0 & 0.8 & 1.3 & 0.1 & 847.9 & 38135.0 & 655.7 & 32630.0 & 338,9 \\
\hline 354 & 22.0 & 4.1 & 0.9 & 1.6 & 0.1 & 872.4 & 46820.0 & 675.7 & 31200.0 & 348,35 \\
\hline 369 & 17.8 & 4.5 & 0.8 & 1.4 & 0.1 & 872.7 & 40315.0 & 666.2 & 31790.0 & 332,35 \\
\hline 385 & 15.1 & 4.1 & 0.9 & 1.6 & 0.1 & 947.8 & 47095.0 & 651.8 & 31210.0 & 340,9 \\
\hline 406 & 32.6 & 4.4 & 0.4 & 1.1 & 0.1 & 941.8 & 26645.0 & 745.0 & 33760.0 & 359,25 \\
\hline $\min$ & 14.3 & 3.9 & 0.1 & 0.7 & 0.0 & 781.8 & 16060.0 & 558.9 & 28580.0 & 293,1 \\
\hline $\max$ & 32.7 & 5.0 & 1.7 & 4.2 & 0.3 & 1611.0 & 62715.0 & 870.9 & 37335.0 & 373,4 \\
\hline mean & 21.1 & 4.5 & 0.5 & 1.4 & 0.1 & 942.9 & 29456.7 & 716.9 & 33992.4 & 345,6 \\
\hline SD & 5.9 & 0.4 & 0.3 & 0.8 & 0.1 & 143.2 & 11119.1 & 85.6 & 2159.0 & 14,7 \\
\hline
\end{tabular}


Appendix A. Table S7. YU2

\begin{tabular}{|c|c|c|c|c|c|c|c|c|c|c|}
\hline $\begin{array}{c}\text { Depth } \\
{[\mathrm{cm} \text { bs] }}\end{array}$ & $\begin{array}{l}\text { Grain size } \\
\text { mean }[\mu \mathrm{m}]\end{array}$ & $\begin{array}{c}\text { Grain size } \\
\text { sorting }\end{array}$ & $\begin{array}{c}\text { TIC } \\
{[w t \%]}\end{array}$ & $\begin{array}{c}\text { TC } \\
{[w t \%]}\end{array}$ & $\begin{array}{c}\text { TN } \\
{[w t \%]}\end{array}$ & $\begin{array}{c}\mathbf{P} \\
{[\mathrm{mg} / \mathbf{k g}]}\end{array}$ & $\begin{array}{c}\mathrm{Ca} \\
{[\mathrm{mg} / \mathrm{kg}]}\end{array}$ & $\begin{array}{c}\text { Mn } \\
{[\mathrm{mg} / \mathrm{kg}]}\end{array}$ & $\begin{array}{c}\text { Fe } \\
{[\mathrm{mg} / \mathrm{kg}]}\end{array}$ & $\begin{array}{c}\mathrm{Zr} \\
{[\mathrm{mg} / \mathrm{kg}]}\end{array}$ \\
\hline 10 & 14.4 & 4.0 & 1.3 & 3.6 & 0.2 & 748.3 & 30250.0 & 738.4 & 31525.0 & 283,45 \\
\hline 28 & 12.7 & 4.0 & 0.6 & 1.4 & 0.1 & 671.6 & 26340.0 & 613.9 & 34355.0 & 273,85 \\
\hline 44 & 15.9 & 4.2 & 0.4 & 0.9 & 0.1 & 737.9 & 25090.0 & 627.4 & 31570.0 & 367,4 \\
\hline 65 & 14.1 & 4.5 & 0.2 & 0.9 & 0.1 & 817.5 & 18890.0 & 659.1 & 31555.0 & 370,6 \\
\hline 82 & 16.7 & 4.1 & 0.2 & 0.7 & 0.1 & 936.5 & 18685.0 & 707.2 & 31000.0 & 377,8 \\
\hline 152 & 15.8 & 4.3 & 0.6 & 1.1 & 0.0 & 875.4 & 30080.0 & 699.7 & 32520.0 & 351,55 \\
\hline 168 & 19.0 & 4.0 & 0.5 & 1.0 & 0.0 & 928.4 & 28085.0 & 631.7 & 32930.0 & 363,75 \\
\hline 194 & 15.7 & 4.3 & 0.5 & 1.0 & 0.1 & 885.9 & 26045.0 & 601.4 & 31860.0 & 363,55 \\
\hline 207 & 15.9 & 4.2 & 0.7 & 1.2 & 0.1 & 851.5 & 31760.0 & 652.2 & 32045.0 & 358,75 \\
\hline 230 & 16.7 & 4.2 & 0.6 & 1.2 & 0.1 & 878.0 & 28100.0 & 653.0 & 32365.0 & 358 \\
\hline 247 & 13.8 & 4.5 & 0.9 & 1.7 & 0.1 & 876.9 & 39645.0 & 796.7 & 34000.0 & 327,2 \\
\hline 277 & 14.8 & 4.3 & 0.9 & 1.7 & 0.1 & 924.9 & 41290.0 & 730.9 & 33750.0 & 328,1 \\
\hline 293 & 14.9 & 4.2 & 0.8 & 1.6 & 0.1 & 886.0 & 36900.0 & 752.7 & 33975.0 & 326,2 \\
\hline $\min$ & 12.7 & 4.0 & 0.2 & 0.7 & 0.0 & 671.6 & 18685.0 & 601.4 & 31000.0 & 273,9 \\
\hline $\max$ & 19.0 & 4.5 & 1.3 & 3.6 & 0.2 & 936.5 & 41290.0 & 796.7 & 34355.0 & 377,8 \\
\hline mean & 15.4 & 4.2 & 0.6 & 1.4 & 0.1 & 847.6 & 29320.0 & 681.8 & 32573.1 & 342,3 \\
\hline SD & 1.5 & 0.2 & 0.3 & 0.7 & 0.0 & 78.3 & 6663.0 & 57.9 & 1079.1 & 31,7 \\
\hline
\end{tabular}


Appendix A. Table S8. YU3

\begin{tabular}{|c|c|c|c|c|c|c|c|c|c|c|}
\hline $\begin{array}{c}\text { Depth } \\
{[\mathrm{cm} \text { bs] }}\end{array}$ & $\begin{array}{l}\text { Grain size } \\
\text { mean }[\mu \mathrm{m}]\end{array}$ & $\begin{array}{c}\text { Grain size } \\
\text { sorting }\end{array}$ & $\begin{array}{c}\text { TIC } \\
{[w t \%]}\end{array}$ & $\begin{array}{c}\text { TC } \\
{[w t \%]}\end{array}$ & $\begin{array}{c}\text { TN } \\
{[w t \%]}\end{array}$ & $\begin{array}{c}P \\
{[\mathrm{mg} / \mathrm{kg}]}\end{array}$ & $\begin{array}{c}\mathrm{Ca} \\
{[\mathrm{mg} / \mathrm{kg}]}\end{array}$ & $\begin{array}{c}\text { Mn } \\
{[\mathrm{mg} / \mathrm{kg}]}\end{array}$ & $\begin{array}{c}\mathrm{Fe} \\
{[\mathrm{mg} / \mathrm{kg}]}\end{array}$ & $\begin{array}{c}\mathrm{Zr} \\
{[\mathrm{mg} / \mathrm{kg}]}\end{array}$ \\
\hline 30 & 18.4 & & 1.2 & 1.9 & 0.1 & 637.0 & 38950.0 & 642.9 & 31140.0 & 329,7 \\
\hline 38 & 17.4 & 4.3 & 0.5 & 0.9 & 0.0 & 709.9 & 29600.0 & 633.5 & 30535.0 & 391,05 \\
\hline 81 & 15.6 & & 0.8 & 1.4 & 0.1 & 819.8 & 36405.0 & 783.9 & 34515.0 & 340,2 \\
\hline 92 & 17.3 & 4.4 & 0.8 & 1.4 & 0.1 & 882.0 & 35215.0 & 874.9 & 33890.0 & 329,95 \\
\hline 100 & 16.1 & 4.3 & 0.5 & 1.2 & 0.1 & 1021.0 & 26270.0 & 800.5 & 36135.0 & 352,2 \\
\hline 113 & 16.7 & 4.5 & 0.6 & 1.2 & 0.1 & 1081.0 & 27845.0 & 693.1 & 35505.0 & 343,75 \\
\hline 149 & 13.7 & 4.4 & 0.3 & 1.3 & 0.1 & 914.4 & 21225.0 & 646.8 & 35730.0 & 344,85 \\
\hline 178 & 14.4 & 4.5 & 0.2 & 1.6 & 0.2 & 963.9 & 19950.0 & 693.5 & 34530.0 & 356,95 \\
\hline 190 & 14.3 & 4.2 & 0.5 & 1.4 & 0.1 & 1047.0 & 27220.0 & 785.8 & 34770.0 & 358,85 \\
\hline 202 & 28.9 & 5.6 & 0.5 & 1.4 & 0.1 & 956.6 & 29920.0 & 773.2 & 35065.0 & 358,05 \\
\hline 217 & 16.0 & 4.4 & 0.9 & 1.9 & 0.1 & 999.8 & 46155.0 & 760.5 & 32500.0 & 349,1 \\
\hline 235 & 18.5 & 4.3 & 0.9 & 1.9 & 0.1 & 1021.0 & 45090.0 & 729.3 & 32225.0 & 337,8 \\
\hline 255 & 18.6 & 4.2 & 0.7 & 1.8 & 0.1 & 905.7 & 37435.0 & 749.1 & 33130.0 & 348,9 \\
\hline 267 & 18.6 & 4.5 & 0.9 & 2.1 & 0.1 & 1032.5 & 44200.0 & 764.8 & 31325.0 & 343,1 \\
\hline 277 & 15.8 & 4.5 & 0.7 & 1.8 & 0.1 & 932.8 & 38025.0 & 768.9 & 33860.0 & 352,6 \\
\hline $\min$ & 13.7 & 4.2 & 0.2 & 0.9 & 0.0 & 637.0 & 19950.0 & 633.5 & 30535.0 & 329,7 \\
\hline $\max$ & 28.9 & 5.6 & 1.2 & 2.1 & 0.2 & 1081.0 & 46155.0 & 874.9 & 36135.0 & 391,1 \\
\hline mean & 17.3 & 4.5 & 0.7 & 1.5 & 0.1 & 928.3 & 33567.0 & 740.0 & 33657.0 & 349,1 \\
\hline $\mathrm{SD}$ & 3.5 & 0.3 & 0.2 & 0.3 & 0.0 & 121.1 & 8049.6 & 64.7 & 1709.9 & 14,3 \\
\hline
\end{tabular}


Appendix A. Table S9. YU4

\begin{tabular}{|c|c|c|c|c|c|c|c|c|c|c|}
\hline $\begin{array}{c}\text { Depth } \\
{[\mathrm{cm} \text { bs] }}\end{array}$ & $\begin{array}{c}\text { Grain size } \\
\text { mean }[\mu \mathrm{m}]\end{array}$ & $\begin{array}{c}\text { Grain size } \\
\text { sorting } \\
\end{array}$ & $\begin{array}{c}\text { TIC } \\
{[\mathrm{wt} \%]}\end{array}$ & $\begin{array}{c}\text { TC } \\
{[w t \%]}\end{array}$ & $\begin{array}{c}\text { TN } \\
{[\mathbf{w t} \%]}\end{array}$ & $\begin{array}{c}P \\
{[\mathrm{mg} / \mathrm{kg}]}\end{array}$ & $\begin{array}{c}\mathrm{Ca} \\
{[\mathrm{mg} / \mathrm{kg}]}\end{array}$ & $\begin{array}{c}\text { Mn } \\
{[\mathrm{mg} / \mathrm{kg}]}\end{array}$ & $\begin{array}{c}\mathrm{Fe} \\
{[\mathrm{mg} / \mathrm{kg}]}\end{array}$ & $\begin{array}{c}\mathrm{Zr} \\
{[\mathrm{mg} / \mathrm{kg}]}\end{array}$ \\
\hline 23 & 14.4 & 4.5 & 1.3 & 2.0 & 0.1 & 677.0 & 36995.0 & 690.1 & 32260.0 & 319,5 \\
\hline 47 & 17.0 & 4.3 & 0.8 & 1.2 & 0.0 & 710.6 & 32730.0 & 722.6 & 32785.0 & 346,4 \\
\hline 80 & 25.2 & 5.2 & 0.6 & 0.9 & 0.0 & 714.5 & 31385.0 & 655.6 & 32370.0 & 350,8 \\
\hline 90 & 22.2 & 4.6 & 0.5 & 0.8 & 0.0 & 848.6 & 28270.0 & 604.9 & 32820.0 & 356,9 \\
\hline 115 & 20.5 & 4.0 & 0.5 & 0.8 & 0.0 & 899.9 & 26610.0 & 604.8 & 33915.0 & 356,35 \\
\hline 127 & 22.0 & 5.1 & 0.5 & 0.9 & 0.0 & 894.5 & 29430.0 & 657.1 & 33985.0 & 358,2 \\
\hline 150 & 15.6 & 4.5 & 0.6 & 0.9 & 0.0 & 890.2 & 27415.0 & 646.8 & 34365.0 & 343,15 \\
\hline 175 & 29.1 & 5.0 & 0.7 & 1.5 & 0.1 & 922.3 & 35160.0 & 821.5 & 33665.0 & 371 \\
\hline 185 & 25.2 & 4.9 & 0.5 & 1.4 & 0.1 & 910.7 & 26405.0 & 748.9 & 34840.0 & 356,25 \\
\hline 200 & 16.2 & 4.5 & 0.2 & 1.6 & 0.2 & 956.9 & 18890.0 & 829.0 & 36210.0 & 360,45 \\
\hline 219 & 18.9 & 4.7 & 0.3 & 2.0 & 0.2 & 1081.5 & 22180.0 & 858.5 & 35925.0 & 344,35 \\
\hline 228 & 19.3 & 4.7 & 0.1 & 2.1 & 0.2 & 1061.0 & 17730.0 & 702.9 & 35315.0 & 356,1 \\
\hline 256 & 16.6 & & 0.1 & 2.7 & 0.3 & 1057.5 & 15670.0 & 729.1 & 35630.0 & 337,65 \\
\hline 274 & 18.2 & 4.3 & 0.5 & 2.1 & 0.2 & 1131.5 & 31125.0 & 723.9 & 34850.0 & 338,55 \\
\hline 290 & 19.6 & 4.7 & 0.6 & 2.5 & 0.2 & 1215.0 & 32620.0 & 761.7 & 35050.0 & 354,45 \\
\hline 316 & 15.8 & 4.4 & 0.3 & 2.2 & 0.2 & 1055.5 & 22070.0 & 785.9 & 36665.0 & 349,85 \\
\hline 324 & 20.8 & 4.7 & 0.4 & 1.9 & 0.2 & 1124.5 & 26370.0 & 772.8 & 35460.0 & 350,25 \\
\hline $\min$ & 14.4 & 4.0 & 0.1 & 0.8 & 0.0 & 677.0 & 15670.0 & 604.8 & 32260.0 & 319,5 \\
\hline $\max$ & 29.1 & 5.2 & 1.3 & 2.7 & 0.3 & 1215.0 & 36995.0 & 858.5 & 36665.0 & 371,0 \\
\hline mean & 19.8 & 4.6 & 0.5 & 1.6 & 0.1 & 950.1 & 27120.9 & 724.5 & 34477.1 & 350,0 \\
\hline SD & 3.9 & 0.3 & 0.3 & 0.6 & 0.1 & 152.4 & 5956.2 & 73.6 & 1321.3 & 11,1 \\
\hline
\end{tabular}


Appendix A. Table S10. YU5

\begin{tabular}{|c|c|c|c|c|c|c|c|c|c|c|}
\hline $\begin{array}{c}\text { Depth } \\
{[\mathrm{cm} \text { bs] }}\end{array}$ & $\begin{array}{c}\text { Grain size } \\
\text { mean }[\mu \mathrm{m}]\end{array}$ & $\begin{array}{c}\text { Grain size } \\
\text { sorting } \\
\end{array}$ & $\begin{array}{c}\text { TIC } \\
{[\mathrm{wt} \%]}\end{array}$ & $\begin{array}{c}\text { TC } \\
{[w t \%]}\end{array}$ & $\begin{array}{c}\text { TN } \\
{[\mathbf{w t} \%]}\end{array}$ & $\begin{array}{c}P \\
{[\mathrm{mg} / \mathrm{kg}]}\end{array}$ & $\begin{array}{c}\mathrm{Ca} \\
{[\mathrm{mg} / \mathrm{kg}]}\end{array}$ & $\begin{array}{c}\text { Mn } \\
{[\mathrm{mg} / \mathrm{kg}]}\end{array}$ & $\begin{array}{c}\mathrm{Fe} \\
{[\mathrm{mg} / \mathrm{kg}]}\end{array}$ & $\begin{array}{c}\mathrm{Zr} \\
{[\mathrm{mg} / \mathrm{kg}]}\end{array}$ \\
\hline 10 & 17.8 & 4.7 & 0.3 & 1.7 & 0.1 & 814.5 & 29665.0 & 750.3 & 34070.0 & 344,3 \\
\hline 30 & 18.2 & 4.9 & 0.2 & 2.3 & 0.2 & 874.9 & 26335.0 & 737.7 & 34095.0 & 306,2 \\
\hline 50 & 16.0 & 4.4 & 0.4 & 2.2 & 0.2 & 897.4 & 24500.0 & 678.4 & 33935.0 & 328,3 \\
\hline 80 & 16.1 & 4.3 & 0.4 & 2.9 & 0.3 & 962.0 & 24695.0 & 738.2 & 34535.0 & 324,6 \\
\hline 104 & 16.9 & 4.5 & 0.4 & 2.8 & 0.2 & 1028.5 & 29620.0 & 741.4 & 33950.0 & 339,4 \\
\hline 150 & 16.4 & 4.6 & 0.1 & 2.6 & 0.3 & 1036.5 & 16080.0 & 692.5 & 33845.0 & 346,95 \\
\hline 160 & 17.3 & 4.9 & 0.3 & 2.3 & 0.2 & 971.8 & 31205.0 & 730.3 & 33470.0 & 336,4 \\
\hline 176 & 17.0 & 4.4 & 0.2 & 1.9 & 0.2 & 935.0 & 22195.0 & 752.3 & 34290.0 & 345,9 \\
\hline 188 & 21.0 & 5.1 & 0.1 & 1.8 & 0.2 & 966.3 & 17915.0 & 695.4 & 33840.0 & 337,45 \\
\hline 205 & 24.4 & 5.3 & 0.2 & 2.5 & 0.3 & 1001.2 & 19815.0 & 751.3 & 34380.0 & 358,1 \\
\hline 216 & 19.2 & 4.8 & 0.1 & 2.6 & 0.3 & 988.3 & 18655.0 & 772.8 & 34020.0 & 358,05 \\
\hline 232 & 17.7 & 4.8 & 0.5 & 2.2 & 0.2 & 963.5 & 35010.0 & 811.4 & 33230.0 & 369,15 \\
\hline 242 & 27.5 & 4.9 & 0.5 & 2.2 & 0.2 & 920.5 & 30330.0 & 853.0 & 33295.0 & 377,2 \\
\hline 252 & 17.8 & 4.4 & 0.5 & 2.1 & 0.2 & 951.1 & 28755.0 & 768.6 & 33560.0 & 364,45 \\
\hline 272 & 21.2 & 4.8 & 0.3 & 2.0 & 0.2 & 938.3 & 21745.0 & 797.3 & 34605.0 & 357,3 \\
\hline 291 & 19.4 & 4.9 & 0.3 & 2.1 & 0.2 & 896.9 & 22195.0 & 737.0 & 33480.0 & 363,3 \\
\hline 309 & 19.0 & 4.8 & 0.5 & 1.9 & 0.2 & 870.4 & 29625.0 & 772.9 & 34000.0 & 345,05 \\
\hline $\min$ & 16.0 & 4.3 & 0.1 & 1.7 & 0.1 & 814.5 & 16080.0 & 678.4 & 33230.0 & 306,2 \\
\hline $\max$ & 27.5 & 5.3 & 0.5 & 2.9 & 0.3 & 1036.5 & 35010.0 & 853.0 & 34605.0 & 377,2 \\
\hline mean & 19.0 & 4.7 & 0.3 & 2.2 & 0.2 & 942.2 & 25196.5 & 751.8 & 33917.6 & 347,2 \\
\hline SD & 3.0 & 0.3 & 0.1 & 0.3 & 0.0 & 56.8 & 5260.4 & 42.2 & 396.4 & 17,3 \\
\hline
\end{tabular}


Appendix B. Figure S1. Ordination plot of PC2 against PC3

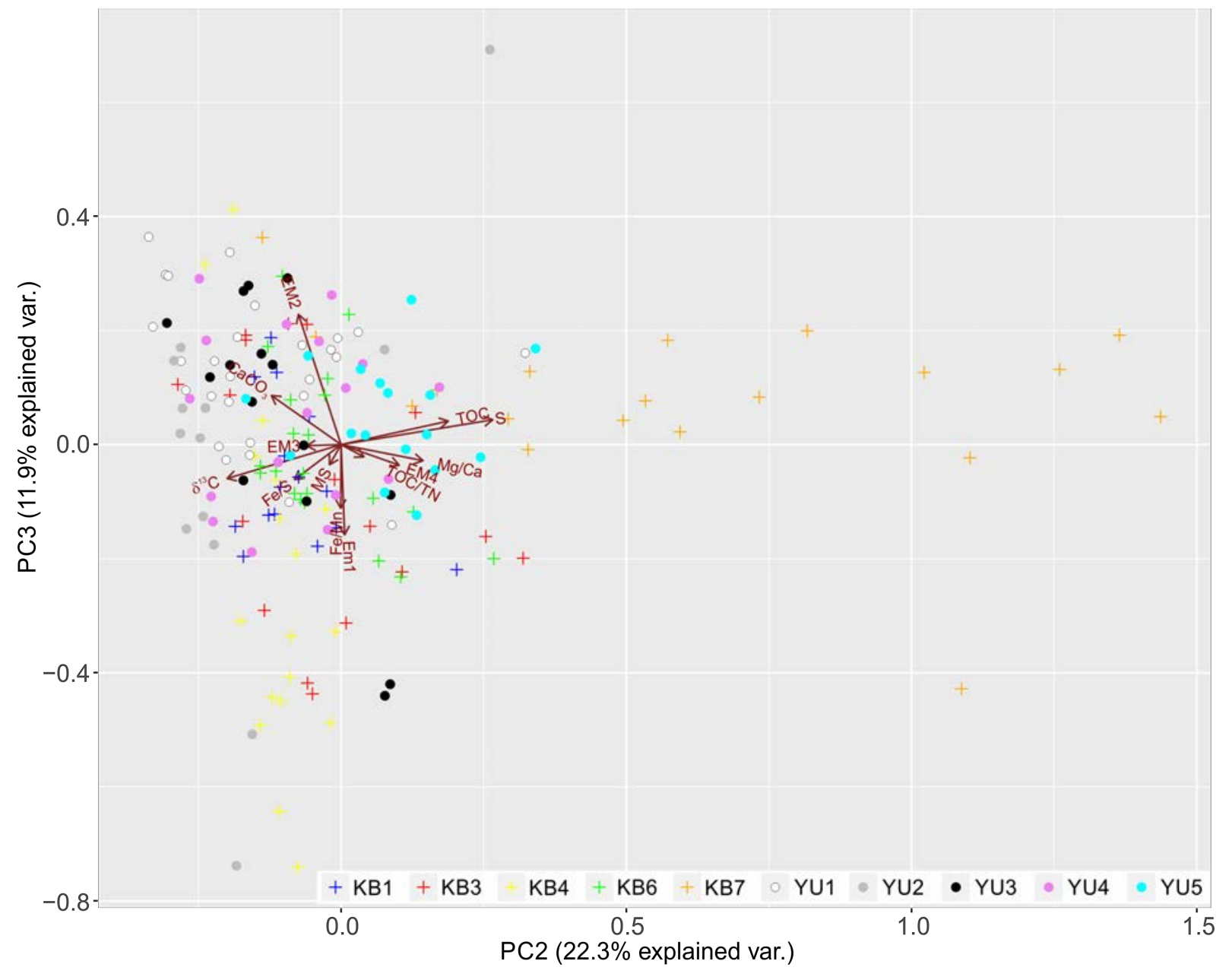


Appendix B. Figure S2. Ordination plot of PC3 against PC4

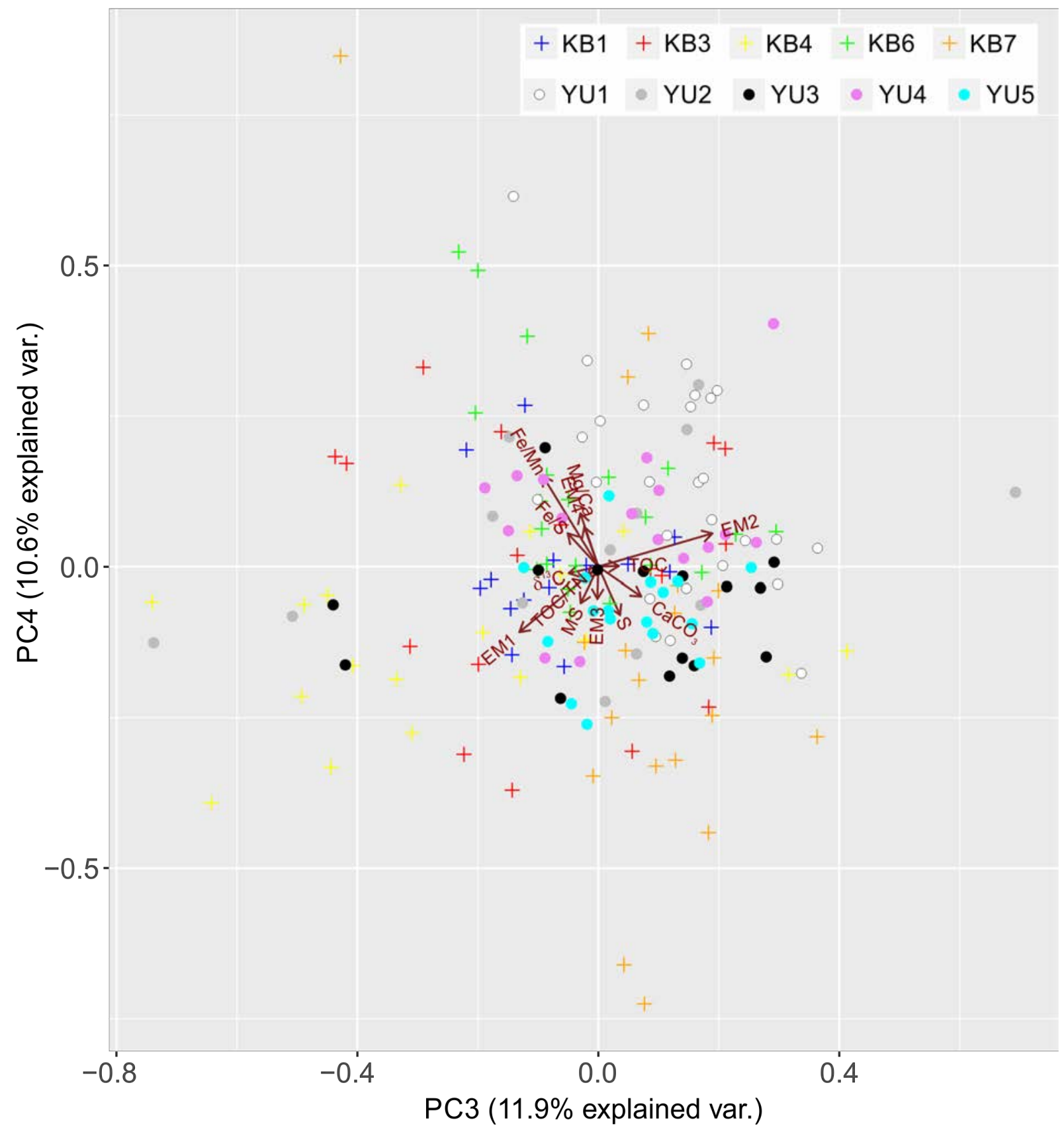


Appendix B. Figure S3. Ordination plot of PC4 against PC5

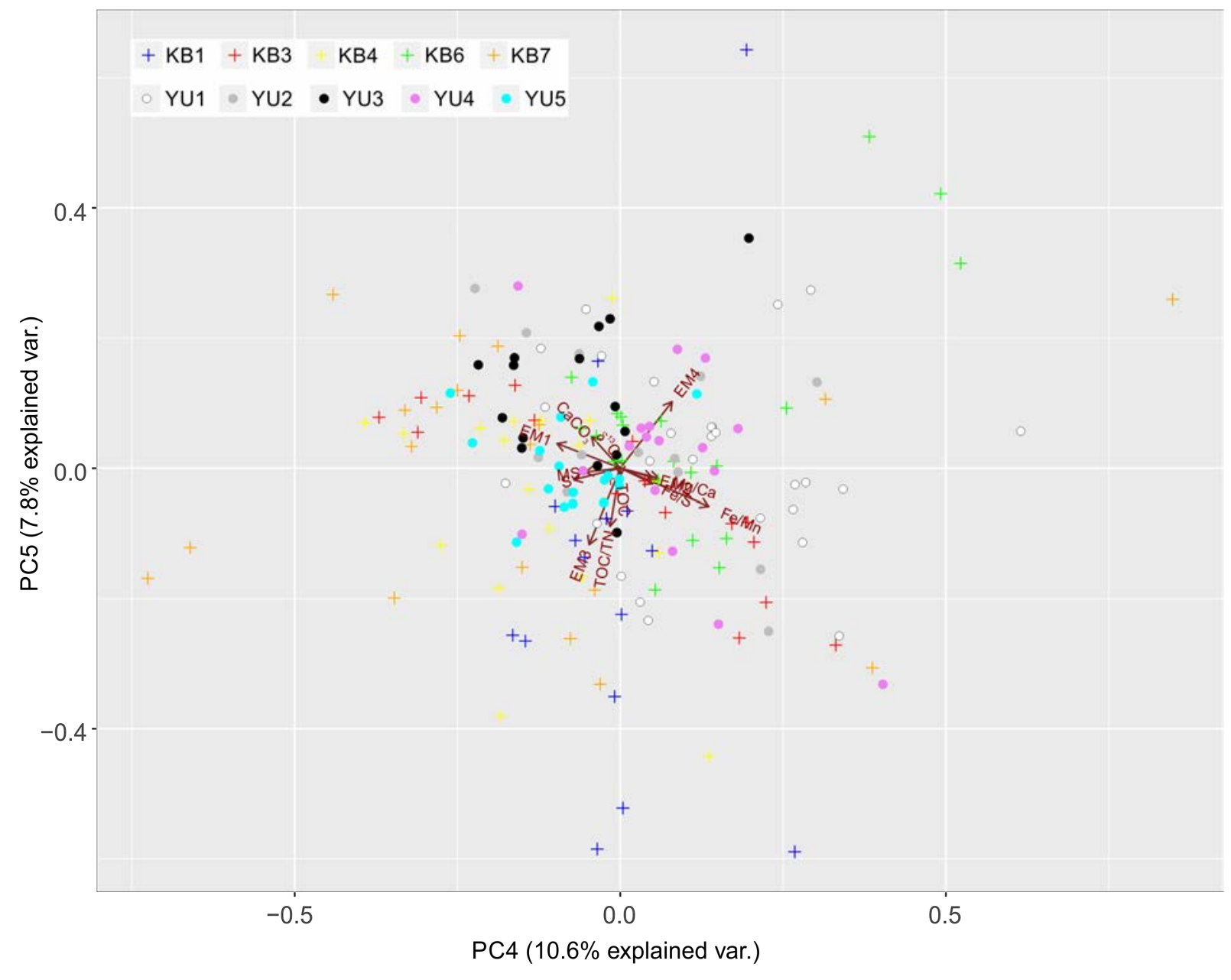

